\title{
What's in a Name? The Collegiate Mark, the Collegiate Model, and the Treatment of Student-Athletes
}

Introduction

A. Amateurism Redux.

B. Amateurism on Campus and the NCAA

II. Athletic Spending and Student-Athlete Benefits

A. The Campus ................................................................... 895

B. The Big Money and Where It Goes ............................. 899

C. The NCAA and Student-Athletes.................................. 903

\footnotetext{
* Josephine (Jo) R. Potuto is the Richard H. Larson Professor of Constitutional Law at the University of Nebraska College of Law. She is the university's faculty athletics representative (FAR), a required campus position at all NCAA member institutions. Potuto served nine years as a member of the Committee on Infractions (two years as chair); more than four years on the Division I Management Council, including service on both its Legislative Review and Administrative Review Subcommittees; and also served as a member of the NCAA Special Review Committee that evaluated and made operational a special consultant's report on enforcement and infractions.

$\dagger$ William H. Lyons is the Richard H. Larson Professor of Tax Law at the University of Nebraska College of Law. Lyons served as Professor-in-Residence to the Chief Counsel of the Internal Revenue Service, is the Managing Editor of The Tax Lawyer (published by the Tax Section of the American Bar Association), a former Committee Chair in the Tax Section, and a Fellow (and former Regent) of the American College of Tax Counsel. Both Lyons and Professor Potuto much appreciate the support of the University of Nebraska College of Law through its McCollum Summer Research Fund.

$\$$ Kevin Rask is a College Research Professor in the Department of Economics and Business at Colorado College. Rask holds an MA and $\mathrm{PhD}$ in Economics from Duke University. He teaches courses in the economics of higher education and econometrics. His current research is focused on student choice, university spending, and the labor market outcomes associated with a college degree. Rask has also served as a consultant to over twenty colleges, universities, and law schools on issues relating to admissions, financial aid, and athletic aid.
} 
III. NCAA Amateurism Bylaws ................................................ 904

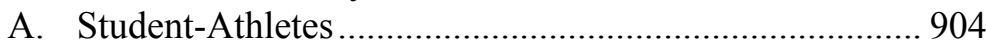

B. NCAA, Conferences, and Universities .......................... 905

IV. Keller/O'Bannon Litigation................................................ 908

A. Legal Claims, in General and in Brief............................ 909

B. EA Sports Videogames ............................................... 911

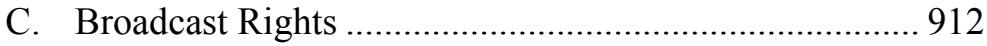

1. Financial Consequences ......................................... 915

2. More than Financial - the Collegiate Mark and the Slippery Slope ................................................. 916

V. Valuing an FBS Football Student-Athlete and a Division I Men's Basketball Student-Athlete.......................................... 918

A. Preliminary Comments................................................ 918

1. Athletic Department Revenue Accounting............... 920

a. Revenues ......................................................... 920

b. Matching Expenses ........................................... 921

2. Marginal Revenue Product ...................................... 922

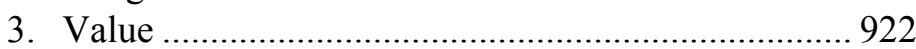

B. The Literature on the Value of a Division I Student-

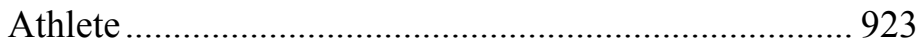

C. Analysis of Econometric Model.................................... 926

1. Data and Methodology ............................................926

2. Descriptive Information ............................................ 928

3. Specification Issues and Models .............................. 930

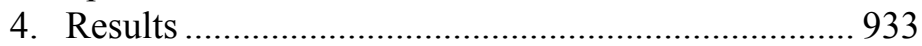

VI. Accommodating Student-Athlete Name and Likeness Compensation Within the Collegiate Model ......................... 937

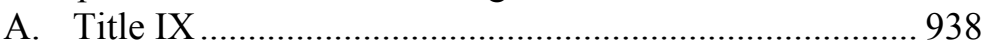

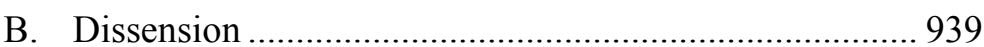

VII. Federal and State Income Tax Consequences of Making

Name and Likeness Payments to Student-Athletes ............... 942

A. University-Established Holding Accounts ..................... 943

1. The Constructive Receipt Doctrine .......................... 944

2. The Economic Benefit Doctrine ............................... 945

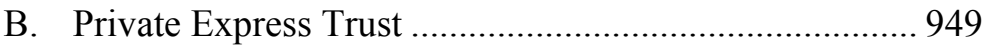

1. Trust Law Issues......................................................... 949

2. Income Tax Issues Associated with Using a Trust... 950

3. Resolving the Quandary ........................................... 952

VIII. The Drift in the Collegiate Model ....................................... 954

A. How Revenue Is Generated.......................................... 954

1. Merchandise, O.K. .................................................... 955 
2. Merchandise, Not O.K. .......................................... 956

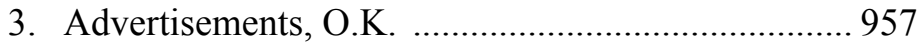

4. Advertisements, Not O.K. ........................................ 957

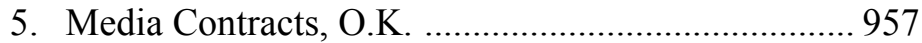

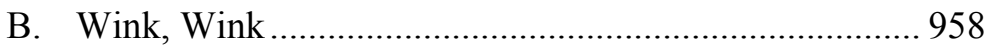

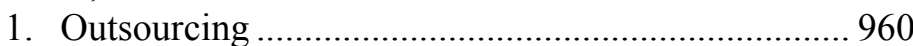

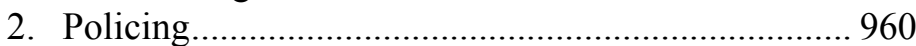

C. How Money Is Spent and Exempt Status for Federal Income Tax Purposes ................................................... 961

IX. A New Paradigm ................................................................. 962

A. Doing More for Student-Athletes................................... 962

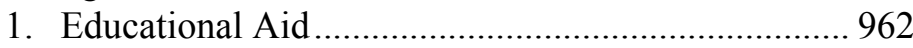

2. Fair and Equitable Treatment ................................. 963

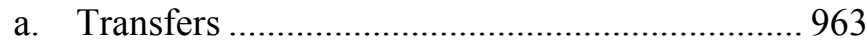

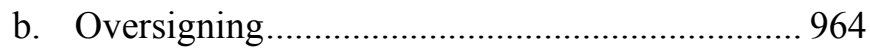

c. Play/Practice Limits ............................................ 964

d. Assistance in Evaluating Professional Potential ............................................................. 965

e. Independent Voice in Student-Athlete Reinstatement Processes ................................... 966

f. Health and Well-Being ...................................... 966

B. Aligning with the Collegiate Model .............................. 967

C. The Flip Side of Name and Likeness: StudentAthletes Marketing Themselves.................................. 967

1. Emma Watson vs. Sam Keller.................................. 968

2. What's Good for the Goose .................................... 971

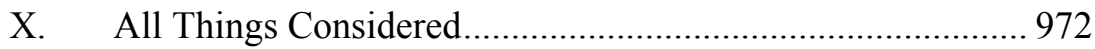

A. Negative Consequences............................................... 972

B. What Might Be Done .................................................... 974

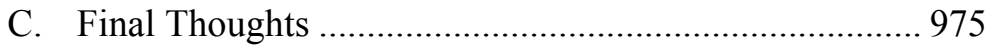

Appendix Table 1: Econometric Estimates from the College

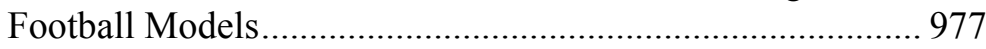

Appendix Table 2: Econometric Estimates from the Men's

College Basketball Models.................................................... 978

\section{INTRODUCTION} he amateurism principle has been a mainstay of college athletics,
at least since the inception of the National Collegiate Athletic 
Association (NCAA) ${ }^{1}$ in $1906 .^{2}$ In its narrowest sense, it means that athletes who are, or have been, paid to play are thereby ineligible to compete in varsity athletic competition. ${ }^{3}$ More broadly, it means that student-athletes professionalize themselves if they capitalize financially on their athletic skill or reputation. ${ }^{4}$

The amateurism principle forms part of the "collegiate model" of intercollegiate athletics whereby university athletic programs are to be "a vital part of the educational system,", student-athletes are to be "an integral part of the student body," and there is to be "a clear line of demarcation between intercollegiate athletics and professional sports." In turn, the collegiate model advances the "collegiate mark" - a market product for collegiate athletics that is separate from the market for professional sports.

Certainly, there is something essentially right in requiring that those who compete on a university athletic team must be students at that university in more than name only. ${ }^{8}$ Equally, there is something essentially right in expecting university athletic departments to advance the values of higher education both on their own, and also through the NCAA and the athletic conferences to which they belong. Because intercollegiate athletics are an important aspect of campus life at a significant number of universities, there also is something essentially right in maintaining a collegiate mark separate from professional sports, thereby insulating fan interest, donor support, and revenue streams. Without these, the viability of intercollegiate athletics would be at risk, to the ultimate detriment of all studentathletes and, at many universities, to the ultimate detriment of campus

\footnotetext{
1 The National Collegiate Athletic Association (NCAA) is a private association of fouryear post-high-school educational institutions that derives its authority from the member institutions that created it. NCAA, 2013-14 NCAA DIVISION I MANUAL § 3.02.3.1 [hereinafter NCAA MANUAL], available at http://www.ncaapublications.com/product downloads/D114.pdf. All citations to NCAA Constitutional Articles and Bylaws are to the 2013-14 Division I manual.

2 G. WAlter Byers \& Charles HAMMER, UnSPORTSMANLIKE CONDUCT: EXPLOITING COLLEGE ATHLETES 40 (1995) (describing the amateurism principle in the 1906 NCAA manual) [hereinafter BYERS].

3 Id.; NCAA MANUAL, supra note $1, \S 12.1 .2$.

4 NCAA MANUAL, supra note $1, \S 12.5 .2$.

5 Id. $\S 1.3 .1$.

${ }^{6} \mathrm{Id}$.

7 Id.

8 But see ANDREW ZIMBALIST, UNPAID PROFESSIONALS: COMMERCIALISM AND Conflict IN Big-Time COllege Sports 200 (Princeton Univ. Press 1999) [hereinafter ZIMBALIST].
} 
life. The collegiate model, then, gets it right. But, and it is a big but, only if it is more than simply aspirational or is not, as many critics would have it, simply a shell game by which revenues that otherwise might go to student-athletes instead feed bloated athletic department budgets and coach salaries.

We live in a world bound by finites, where policy articulation and implementation rarely achieve perfection and where group decisions are compromises that balance a variety of competing interests. No matter the policy choice, there often are outlier undesirable consequences. Inevitably, then, NCAA and institutional articulation and enforcement of the collegiate model will have aspects ripe for critical picking. Almost with the first game played on a college campus, critics have claimed that intercollegiate athletic programs do not promote the goals of higher education, but rather subvert or engulf them. ${ }^{9}$ These complaints have reached a crescendo.

It is simply impossible today to have even a passing interest in college sports and fail to hear the cacophony of complaints that college athletics are not amateur athletics, but instead are big business divorced from the campus ethos ${ }^{10}$ - at least at the major NCAA Division $\mathrm{I}^{11}$ Football Bowl Subdivision (FBS) schools ${ }^{12}$ and in the

9 See BYERS, supra note 2, at 1-3, 365-74; see generally ZIMBALIST, supra note 8, at $15,20-26,189$.

10 See, e.g., Frank G. Splitt, Time for Accountability in Sports: Corrupt Collegiate Athletics Overshadow Faltering Academic Mission, NAT'L CATHOLIC REPORTER, Nov. 14, 2008, at 11a; REPORT OF THE KNIGHT FOUND., COMM'N ON INTERCOLLEGIATE Athletics, A CALl to ACtion: ReCONNeCting COllege Sports and Higher Education (2001); Murray SPERber, BeER AND Circus: How Big-Time College SPORTS IS CRIPPLING UNDERGRADUATE EDUCATION (2000); RICK TELANDER, THE HuNDRED YARD LiE: THE CORRUPTION OF COLLEGE FoOTBALl AND WHAT We CAN DO To Stop It (1996); The CoAlition on Intercollegiate Athletics (COIA), A FRAMEWORK FOR COMPREHENSIVE ATHLETICS REFORM (2003); F. WILLIAM G. BOWEN \& Sarah A. Levin, Reclaiming the Game: College Sports and Educational VALUES (Princeton Univ. Press 2003); BYERS, supra note 2; H. JAMES J. DUDERSTADT, INTERCOLLEGIATE ATHLETICS AND THE AMERICAN UNIVERSITY: A UNIVERSITY President's Perspective (2000); James L. Shulman \& William G. Bowen, The Game of Life: College Sports and Educational Values (Princeton Univ. Press 2001); John R. Thelin, Games Colleges Play: ScANDAL AND Reform in INTERCOLLEGIATE ATHLETICS (1994).

11 The NCAA has three divisions (I, II, III). NCAA MANUAL, supra note 1, § 20.01.2. Division I institutions include the largest and most well funded research universities. They must sponsor fourteen sports for which the NCAA operates a postseason championship. Id. $\S 20.9 .6$. For each of these fourteen sports, they must award at least fifty percent of the maximum number of grants-in-aid permitted. Id. § 20.9.3.2. Division I is divided into three subdivisions. Institutions that sponsor football are either in the Football Championship Subdivision (FCS) and play in the NCAA football championship, or are in the Football 
revenue sports of football and men's basketball. In turn, critics reject the idea that a full-ride athletic scholarship, ${ }^{13}$ plus the educational and lifetime economic benefits of a university education, appropriately cabin the full economic scope of what men's basketball and football student-athletes are entitled to derive from their college careers and athletic participation. As these critics see it, the genie is out of the bottle and the amateurism principle must give way.

Some critics mount a frontal attack, seeking a policy capitulation to treat football and men's basketball student-athletes as university employees who should be paid wages to compete. ${ }^{14}$ This so-called pay-for-play model is outside the scope of this Article. ${ }^{15}$ To be clear, however, we oppose its implementation - both because it eliminates a foundational difference between college and professional sports, and because it conflicts with campus treatment and expectations of students who are not athletes. ${ }^{16}$

Bowl Subdivision (FBS) and play in bowl games. Id. $\S \S 20.01 .2$, 20.7.1.1(b), 20.4.1.1. Division I institutions without football are known simply as Division I. Prior to 2006, the FBS was known as Division I-A. For ease of reference, this Article refers to this subdivision uniformly as the FBS, even if its historical designation was Division I-A at the time of a bylaw, case, or research initiative being discussed.

12 FBS institutions must sponsor at least sixteen sports, at least eight of which must be women's sports. Id. $\S 20.9 .9 .1$. In general, FBS football teams must play at least sixty percent of their games against other FBS teams and average at least fifteen thousand dollars in paid attendance computed every two years on a rolling basis. Id. $\S 20.9 .9 .3$. The remaining teams must be in sports for which the NCAA has a post-season championship and meet minimum contest requirements. Id. $\S \S 20.9 .9 .6 .1,20.9 .6 .3$. An FBS conference must have at least eight FBS institutions. Id. § 20.02.6.

13 A full-ride scholarship covers tuition, room and board, required textbooks, and fees. Id. $\S 15.2 .1 .4$.

14 See, e.g., Ronald A. Smith, Pay for Play: A History of Big-Time College ATHLETIC REFORM (2011); Robert A. McCormick \& Amy Christian McCormick, The Myth of the Student-Athlete: The College Athlete as Employee, 81 WASH. L. REV. 71, 71 (2006).

15 The pay-for-play model picked up steam when student-athletes at Northwestern University petitioned the NLRB for recognition as a union. See, e.g., Teddy Greenstein, Northwestern Football Players Seek to Join Labor Union, CHI. TRIB., Jan. 28, 2014, available at http://articles.chicagotribune.com/2014-01-28/sports/chi-northwestern-foot ball-players-labor-union-20140128 1 basketball-players-labor-union-national-labor -relations-board.

16 See generally ZIMBALIST, supra note 8, at 53 (stating that pay for play "is neither economically feasible nor socially desirable"). We recognize, of course, that graduate students are paid to teach undergraduate courses and that student research assistants are paid to assist professors in research projects. These undertakings, however, directly relate to a university's core missions of education and research, and, therefore, are part of the totality of a student's university education. This is particularly true of graduate assistants, who teach in the subject area of their graduate degree. Whatever the value and appropriateness of varsity athletic teams on a college campus, there can be no argument 
Another target for critics, and the catalyst for this Article, is the NCAA prohibition on student-athlete receipt of compensation for the use of their names and likenesses. There are two variants on this theme. First, student-athletes independently might market their names and likenesses in much the same way that the University of Colorado's Jeremy Bloom sought to endorse products. ${ }^{17}$ Second, student-athletes might be paid a percentage of NCAA, conference, or university revenues derived from marketing, promotional, or licensing ventures in which their names and likenesses are used or from their participation in broadcast games.

The debate roiling over the uncompensated use of student-athlete names and likenesses has been long on platitudes, but short on any close analysis of what the NCAA, conferences, and member universities currently do, should do, or might need to do. It is equally short on details of how student-athlete name and likeness compensation might be achieved, including what might be the attendant legal and practical constraints, and on the impact on the collegiate mark and collegiate model. Our purpose in this Article is to fill the void.

Part I of this Article traces the evolution of amateurism. We begin with a short history of the amateurism principle, one with a murkier genesis and evolution than those waxing nostalgic would have it. We then trace the evolution of NCAA and campus treatment of studentathletes pursuant to the amateurism principle.

Part II describes the campus environment and how athletic revenues are spent. It also discusses the monetary value of an athletic scholarship and other benefits afforded student-athletes.

that they are similarly central to a university's mission. Moreover, we note that a pay-forplay model could have serious adverse income tax consequences for universities claiming an exemption from federal (and, if applicable, state) income taxation under section 501(c)(3) of the Internal Revenue Code. 26 U.S.C. § 501(c)(3) (2012). (All citations to the Internal Revenue Code are to the Internal Revenue Code of 1986, as amended, codified in Title 26 of the United States Code.) Revenue generated by athletic programs operated under a pay-for-play model would generate "unrelated business income" subject to federal (and perhaps state) corporate income tax. The pay-for-play model might even result in the university's loss of its section 501(c)(3) income tax exemption for all purposes.

17 Bloom v. NCAA, 93 P.3d 621, 622 (Colo. App. 2004). Before enrolling at Colorado, Bloom was a World Cup skier with offers to host a TV show, model clothes, and endorse products. Id. Once he enrolled at Colorado, however, Bloom had to cease such modeling and endorsement deals because NCAA bylaws made him ineligible for competition if he engaged in these or other paid business opportunities related to his athletic ability. Id.; NCAA MANUAL, supra note $1, \S 12.5 .2 .1$. 
Part III describes and analyzes the current bylaw structure that embodies amateurism in NCAA Division I. We discuss the extent to which the NCAA, conferences, and universities currently engage in marketing and promotional activities. We also discuss NCAA bylaw restrictions, both on such activities and on student-athletes.

Part IV briefly addresses the scope of two lawsuits, subsequently consolidated, brought on behalf of football and men's basketball student-athletes that may resolve whether student-athletes have legal entitlement to revenues from broadcast games in which they participate or from commercial ventures in which their names and likenesses are used. We also discuss the impact on athletic department revenues were student-athletes to be compensated for use of their names and likenesses, and whether a combination of changes over time (the slippery slope, as it were) ultimately might undermine the viability of the collegiate mark to the ultimate detriment of college athletics and all student-athletes.

Part $\mathrm{V}$ provides an econometric model of how one might value what student-athletes are worth, identifies reasons that such valuation is complicated, and highlights limitations in any valuation estimate. We also evaluate other renditions of student-athlete value.

Part VI considers alternatives to the current NCAA Division I bylaw structure, and whether and how the NCAA feasibly might accommodate compensation to student-athletes for use of their names and likenesses. We consider the impact on funding for non-revenue sports and the requisites of gender equity if athletic departments were to divert funds to pay football and men's basketball student-athletes. We also discuss the specter of increased obstacles to NCAA rules enforcement in a highly competitive world in which policing against major rules violations and protecting against illicit well-heeled booster and agent involvement already are significant problems. ${ }^{18}$

Part VII considers how universities might defer paying studentathletes until they no longer are eligible to compete. We then consider the federal tax issues and potential practical impediments attendant on this approach.

Part VIII examines some of the commercial, marketing, and promotional initiatives of the NCAA, conferences, and institutions. We evaluate these initiatives for their impact on the collegiate model.

Part IX sets forth elements of a collegiate model that would preserve the essential centrality of the student part of "student-

18 See infractions reports and authorities cited infra notes 38-39. 
athlete" and the campus part of collegiate athletic competition, but that would also recognize that a century of changes in how universities and athletics departments operate should trigger changes in the treatment of student-athletes.

Finally, in Part X, we identify potential negative consequences to athletic programs and the greater campus were more funds and services to be directed to student-athletes, including cutting sports and diverting even more money from the greater campus to athletics. We also suggest ways to temper policy decisions that lead to these consequences.

\section{I}

AMATEURISM

Many sing the praises of amateurism as (they think) it was. They revere the ancient Greeks who exemplified, they say, the Platonic ideal of mind and body combined. ${ }^{19}$ They laud the absence of commercial motive or exploitation in the ancient Olympic Games. They rhapsodize about competition for the sake of competition and amateur athletes who policed themselves and did not cheat to win. They yearn for the days when athletic competition was divorced from political influence.

It is a lovely, uplifting tale. The only trouble is, it was never thus.

\section{A. Amateurism Redux}

Among others, David Gilman Romano, the Karabots Professor of Greek Archaeology at the School of Anthropology of the University of Arizona, has described amateurism in ancient times. ${ }^{20}$ According to Romano, the word "athlete" seems to combine two Greek words"athlos," meaning contest, and "athlon" meaning prize. ${ }^{21}$ An athlete in ancient Greece, therefore, was someone who competed for a prize. And, the prize was pretty good. According to Plutarch, in $600 \mathrm{BC}$, a citizen of Athens who won an Olympic event would receive a cash

\footnotetext{
19 See generally Verity Harte, Plato's Metaphysics, in THE OXFORD HANDBOOK OF PLATO 191 (Gail Fine ed., 2011); C.C.W. Taylor, Plato's Epistemology, in THE OXFORD HANDBOOK OF PlATO 165 (Gail Fine ed., 2011).

20 See David Gilman Romano, The FAQs: Modern Myths of The Ancient Olympic Games, UnIV. OF PA. MUSEUM OF ARCHAEOLOGY \& ANTHROPOLOGY, http://www.penn .museum/sites/olympics/olympicfaqs.shtml (last visited Mar. 8, 2014).

${ }^{21} I d$.
} 
award of five hundred drachma, ${ }^{22}$ enough to support a family of three for thirty-three months. ${ }^{23}$

Political influence and cheating scandals also occurred. ${ }^{24}$ Athletes were known to claim citizenship for competition depending on how large the bribe. As to commercialization, the ancient Greek equivalents are odes to athletes (sometimes commissioned by the athletes themselves), commemorative coins, and statues. ${ }^{25}$

Now fast forward to the nineteenth-century iteration of amateurism in Great Britain ${ }^{26}$ and the modern understanding that amateurs compete for the sake of the competition and not for the money. Amateurism to Victorians embodied neither a laudatory nor even benign ideal of the nature of athletic competition. Instead, amateurism fostered class-consciousness. ${ }^{27}$ If only amateurs could compete, then competition necessarily could be reserved for the "gentlemen" leisure class or at least would extend no further than the upper middle class. ${ }^{28}$

\footnotetext{
22 Id.

23 One half of a drachma reportedly could support a family of three for one day. See, e.g., Xenophon, Ways and Means: A Pamphlet on Revenues n.18 (H.G. Dakyns, trans., Macmillan \& Co., 1897); Aristophanes, Wasps, THE COMPLETE DRAMA 2, lines 300-02 (Eugene O’Neill, Jr. ed., 1938), available at http://www.perseus.tufts.edu/hopper /text?doc=Perseus:text:1999.01.0044 (last visited Mar. 10, 2014). THUCYDIDES, HISTORY OF THE PELOPONNESIAN WAR, 3.17.4 (Thomas Hobbes ed., 1843).

24 See Christopher Klein, 5 Myths About the Ancient Olympics, History in the Headlines, HistoRY.COM (Aug. 10, 2012), http://www.history.com/news/5-myths-about -the-ancient-olympics.

25 Id.

26 A nineteenth century where the sun never set on the British Empire; where native populations in India were subjugated in their own land; and where jingoism reigned. David Cody, Kipling's Imperialism, VICTORIAN WEB, http://www.victorianweb.org/authors /kipling/rkimperialism.html (last updated 1988). See generally PAUL SCOTT, THE JEWEL IN THE CROWN: THE RAJ QUARTET: I (Univ. of Chi. Press 1998). A nineteenth century where existed poverty, squalor, workhouses for the poor, and debtor prisons. See generally Charles Dickens, Oliver Twist (2002); Charles Dickens, Bleak House (1996). A nineteenth century where married women had no separate identity and lost any independent wealth to their husbands the moment the marriage contract was signed. See Frontiero v. Richardson, 411 U.S. 677, 685 (1973).

27 Mike Huggins, The Victorians AND SPORT 52, 54-56 (2004) [hereinafter HUGGINS] (noting that "[a]mateurism, accompanied by snobbishness, hypocrisy and double standards, became emblematic of class" and "a way of keeping working class players in their place or keeping them out"). See generally DAVID CANNADINE, THE DECLINE AND FALL OF THE BRITISH ARISTOCRACY 8-15 (1996).

28 HugGins, supra note 27, at 19-83.
} 


\section{B. Amateurism on Campus and the NCAA}

Athletic competition came to campus in the early nineteenth century. ${ }^{29}$ Centralized administration of intercollegiate competition began to develop in 1906 with the formation of the NCAA. ${ }^{30}$

Early twentieth-century universities primarily were open only to those whose families could afford the price. General liberal arts curriculum was not geared toward employment after graduation. ${ }^{31}$ Scholarship assistance was limited. ${ }^{32}$ College athletic competition understood as competition among unpaid amateurs fit well on these campuses. Amateurism also was a good fit when college sports-even football-generated neither large revenues nor much national public attention. $^{33}$ At least by the 1980 s, however, things had changed dramatically, ${ }^{34}$ and they continue to change.

29 BYERS, supra note 2 , at 38-40.

${ }^{30}$ Id. At least in part, the NCAA was formed as a result of the large number of studentathlete injuries and deaths. Id.

31 It was only in 1862, with the passage of the Morrill Act of 1862, that the mission of universities expanded beyond the liberal arts to include degree programs that prepared students more directly for employment after graduation. See Celebrating the Morrill Act of 1862, Colo. ST. UNIV. (Jan. 2013), http://www.colostate.edu/morrillact/. Land grant universities then transformed into public universities with missions to provide wide access. See Elise Young, 150 Years of College Access, INSIDE HIGHER ED (June 27, 2012), http://www.insidehighered.com/news/2012/06/27/birthday-celebration-land-grant-colleges -get-advice-about-their-future; see also Aaron Cooley, Higher Education Act (HEA), LAWHIGHEREDUCATION.ORG (May 1, 2011), http://lawhighereducation.org/75-higher -education-at-hea.html?newsid=75\&seourl=higher-education-at-hea.

32 States to varying degrees began to provide need-based assistance. It was only in 1965, with the passage of the Higher Education Act, however, that the federal government took significant steps to make college education affordable to those priced out by financial need.

33 Even in the $1880 \mathrm{~s}$, some college football teams generated a lot of public attention and, at the time, fairly substantial revenues. ZIMBALIST, supra note 8 , at 7 . For example, Princeton-Yale football games were played in front of forty thousand fans and produced revenues equivalent to $\$ 420,000$ in 1998 dollars. Id. But, the attention primarily was local, not national, and these instances were not by any means universal. Id.

34 In 1984, the Supreme Court held that the NCAA illegally restrained trade under the federal antitrust laws when it limited the number of times individual football teams could appear on television. NCAA v. Bd. of Regents, 468 U.S. 85 (1984). This decision opened the floodgates for huge conference television deals and increased the difference between major football schools and others in the amount of revenues they generated. See Josephine R. Potuto, They Take Classes, Don't They?: Structuring a College Football Post Season, 7 J. BUS. \& TECH. LAW, 311 (2012); Lenn Robbins, Smaller Conferences Need Their Own Playoff, N.Y. POST (July 27, 2013), http://www.nypost.com/p/sports/college/football /smaller Conferences need their_own AuadB8EPOfZ90DgmdUUx9O; George Schroeder, College Football Playoff Revenue Distribution Set, USA TODAY (Dec. 12, 
Early NCAA efforts to mesh student-athletes with students who were not athletes required that athletic scholarships be need-based, ${ }^{35}$ and that athletic scholarship awards be decided by campus academic administrators and not by coaches. ${ }^{36}$ Over time, varsity athletic competition mutated from an extra-curricular student avocation to a year-round focused commitment. Similarly, interest in college teams and players extended beyond students, faculty, and alumni at an individual school to substantial, even national, fan bases and donor support, often from those who neither attended nor were employed by the university they supported.

Increased athletic time demands on student-athletes ${ }^{37}$ excluded realistic opportunities for outside employment. At the same time, booster and agent intrusion into athletic programs led to illicit payments to student-athletes that could be laundered through ostensible bona fide employment. ${ }^{38}$ The NCAA responded with bylaws that eliminated opportunities for student-athletes to be employed in activities related to their athletic skill or reputation and also by increased scrutiny of student-athlete summer jobs. ${ }^{39}$ Ultimately, scholarship awards were tied to athletic participation, not need, and scholarship decisions were made by coaches, not campus administrators. $^{40}$

2012, 12:41 AM), http://www.usatoday.com/story/sports/ncaaf/bowls/2012/12/11/college -football-bcs-playoff-revenue-money-distribution-payouts/1762709/.

35 The switch to full-ride athletic scholarships came in 1952. ZIMBALIST, supra note 8, at 41 (noting that the switch to full-ride athletic scholarships began in 1956).

36 BYERS, supra note 2, at 76.

37 See generally KNIGHT COMM'N ON INTERCOLLEgiATE ATHLETICS, RESTORING THE BAlance: Dollars, VAlues, AND the Future OF COllege SPORTS $§ 3$ (Mar. 6, 2014), available at http://www.knightcommission.org/restoringthebalance/recommendation-iii. Increased time demands are the product of more games, more travel time to games, and time spent on campus over breaks, including summers, to hone skills. Id.

38 There also was a time under NCAA bylaws when boosters could funnel money to particular student-athletes by providing scholarship money earmarked for them. BYERS, supra note 2, at 73.

39 University of Southern CALifornia Public Infractions Report No. 323 (2010); MARSHALL UNIVERSITY PUBLIC INFRACTIONS REPORT NO. 191 (2001).

40 One explanation for these bylaw changes is to avoid the threat that the federal labor laws would cover student-athletes. Equally, however, the bylaw changes may be seen as reasonable accommodations to the time demands of college athletic participation. BYERS, supra note 2, at 69-72. The federal income tax treatment of athletic scholarships seems motivated by a related concern. Section 117(c) of the Internal Revenue Code provides that the exclusion for "qualified scholarships" does not apply "to that portion of any amount received which represents payment for teaching, research, or other services by the student required as a condition for receiving the qualified scholarship . ..." 26 U.S.C. § 117(c)(1) (2012) (emphasis added). Although an athletic scholarship might appear to fall within 
Although the amateurism principle is part of assuring that studentathletes are treated similarly to students who are not athletes, the foremost criterion of similar treatment comes from NCAA bylaws requiring uniform application to both cohorts of university admissions, grading, and degree requirement standards and decisions. At its inception, however, the NCAA imposed no additional academic requirements for competition eligibility. ${ }^{41}$ Instead, all academic decisions were local to each university. ${ }^{42}$

NCAA bylaws now dictate minimum standards for initial eligibility. ${ }^{43}$ Such standards include an academic component that connects NCAA calculation of high school grade-point average to grades and credits in specified core courses. ${ }^{44}$ There also are initial

section 117(c), since 1977, the Internal Revenue Service has taken the position that if a student-athlete is not required to participate in the particular sport, section 117(c) does not prevent the student's athletic scholarship from being an excludable "qualified scholarship":

In the instant case, the university requires no particular activity of any of its scholarship recipients. Although students who receive athletic scholarships do so because of their special abilities in a particular sport and are expected to participate in the sport, the scholarship is not cancelled in the event the student cannot participate and the student is not required to engage in any other activities in lieu of participating in the sport.

Accordingly, in the instant case, the athletic scholarships are awarded by the university primarily to aid the recipients in pursuing their studies, and therefore, the value of the scholarships is excludable from the recipients' gross incomes under section 117 of the Code.

Rev. Rul. 77-263, 1977-2 C.B. 47 (emphasis added). The Revenue Ruling appears to track the NCAA rule that an athletic scholarship, once awarded, must continue for the full period of the award even if the student-athlete decides not to play. As commentators have pointed out, "[t]he apparent flaw in this reasoning is that if the recipient does not choose to play sports, the scholarship need not (and probably will not) be renewed for the following year. Thus . . . to keep his scholarship going from year to year, the recipient must play sports." DANiEl Q. POSIN \& DONALD T. TOBIN, PRINCIPLES OF FEDERAL INCOME TAXATION $\S 3.09$, at 120 (7th ed. 2005) (emphasis added). Although the Revenue Ruling is consistent with NCAA rules, from a tax policy perspective, the Revenue Ruling is difficult, if not impossible, to defend. We note that universities now may award multi-year athletic scholarships. NCAA MANUAL, supra note 1 , $\S \S 15.02 .7,15.3 .3 .1$. As with oneyear scholarship awards, multiyear scholarships may neither be conditioned on a level of athletic performance achieved nor reduced or cancelled because of subpar athletic skill or performance. Id. $\S \S 15.3 .4 .3 .1,15.3 .4 .3$.

41 ZIMBALIST, supra note 8, at 20-22, 26-27.

42 See BYERS, supra note 2, at 309-17; see generally ZIMBALIST, supra note 8, at 2636.

43 NCAA MANUAL, supra note $1, \S 14.3$.

${ }^{44}$ Id. $\S 14.3 .1 .1$. 
eligibility requirements for transfer student-athletes. $^{45}$ NCAA continuing eligibility requirements focus on individual studentathletes and specify progress-toward-degree markers. ${ }^{46}$ The Committee on Academic Performance focuses on team academic performance $^{47}$ and may exclude from NCAA championship competition teams that have a poor record of academic performance. $^{48}$

The NCAA, conferences, and universities have done far less well, however, in administering athletic departments consistent with how colleges administer academic departments (or, for that matter, imposing additional requirements that set a higher standard). Today, college athletics is a multibillion dollar enterprise. Payouts to universities from their conference offices can exceed \$26 million annually, ${ }^{49}$ and such payouts keep growing. ${ }^{50}$ The FBS football championship television deal is worth $\$ 470$ million annually to the FBS conferences, ${ }^{51}$ and there are even more revenues to come from

45 Among them are limits on the number of physical education courses that may count toward eligibility upon transfer to a member institution. Id. § 14.5.4.5.4.

46 The progress-toward-degree requirements are more restrictive than those that apply to students who are not athletes because the NCAA sets additional annual benchmarks that must be met. Id. $\S 14.4$.

47 Id. $\S 21.7 .8 .2$.

48 See APR: Ten Teams Lose Postseason, ESPN.COM (June 20, 2012, 9:23 PM), http://espn.go.com/mens-college-basketball/story/_id/8077431/connecticut-huskies-9 -others-sit-postseason-apr. Team academic performance is calculated by a metric that awards each scholarship student-athlete on a team an eligibility point and a retention point for each semester in which they are eligible to compete and remain on a team. Team totals are computed. Low scores trigger imposition of penalties. The APR metric can be found at Academic Progress Rates (APR), NCAA.ORG, http://www.ncaa.org/about/resources /research/academic-progress-rate-apr (last visited Mar. 10, 2014).

${ }^{49}$ Chris Smith, How Massive Conference Payouts are Changing the Face of College Sports, FORBES (Dec. 26, 2013, 12:25 PM), http://www.forbes.com/sites/chrissmith/2013 /12/26/how-massive-conference-payouts-are-changing-the-face-of-college-sports/.

50 Stu Durando, Big Ten Payouts to Hit \$25.7 Million Per School, St. LouIS PostDisPATCH (May 6, 2013, 9:21 AM), http://www.stltoday.com/sports/college/illini/big-ten -payouts-to-hit-million-per-school/article_4eef1c1a-5a79-5b79-899b-3dbf2a99c871.html. Projections are that Southeastern Conference schools could each receive nearly $\$ 34$ million in 2014-15. Steve Berkowitz, SEC Revenue Set to Jump 50\% with Playoff, New TV Deals, USA TODAY (Jan. 16, 2013, 9:23 PM), http://www.usatoday.com/story/sports /college/2013/01/16/sec-conference-money-increases/1836389/. For a list of major conference broadcast contracts, and their value, see, e.g., Potuto, supra note 34, at 322-23.

51 Rachel Bachman, ESPN Strikes Deal for College Football Playoff, WaLL ST. J. (Nov. 21, 2012), http://online.wsj.com/news/articles/SB10001424127887324851704578 133223970790516. The FBS Conferences are not all equal. The five major conferences are the Big Ten Conference, Pacific 12 Conference, Atlantic Coast Conference, Southeastern Conference, and the Big 12 Conference. These major conferences, along with the 
ticket and merchandise sales. ${ }^{52}$ In forty states, the highest paid public official is a college head coach ( 27 football; 13 men's basketball). ${ }^{53}$ Head football and men's basketball coaches also have side deals that bring them even more money. ${ }^{54}$

Not surprisingly, all this money triggers serious concerns that athletic departments are driven by revenues and profits, rather than by the academic mission of their universities and the best interests of their student-athletes. ${ }^{55}$ All this money also is parent to the perception that everyone but student-athletes gets a big piece of an increasingly bigger pie. ${ }^{56}$ Walter Byers, the NCAA's first full-time executive

American Athletic Conference, formerly were BCS automatic qualifier (AQ) conferences. See Potuto, supra note 34, at 313, 314 n.6, 319-21.

52 As just one example, John Calapari, the former men's basketball head coach of the University of Massachusetts, copyrighted and sold the team slogan, "Refuse to Lose," and he did so even though the slogan was developed by others and initiated with the football team. Michael Rosenberg, Refuse to Lose: Master Salesman Calipari is the Best at what he Does, SI.COM (Mar. 17, 2010, 6:35 PM), http://sportsillustrated.cnn.com/2010/writers /michael_rosenberg/03/17/calipari/. Individual athletic departments generate revenues on their own through, among other things, tickets sales (including suites), donor contributions, and merchandising. See discussion infra Part V. Institutional revenues can even come from their own television networks. For example, the University of Texas has a twenty-year \$300 million deal with ESPN. Matt Hinton, ESPN's All-Longhorn Network is the First of its Kind, but it's too Lucrative to be the Last, YAHOO! SPORTS (Jan. 19, 2013, 9:42 AM), http://sports.yahoo.com/ncaa/football/blog/dr_saturday/post/ESPN-s-all -Longhorn-network-is-the-first-of-its-?urn=ncaaf-309658.

53 Reuben Fischer-Baum, Infographic: Is Your State's Highest-Paid Employee A Coach? (Probably), DEADSPIN.COM (May 10, 2013, 3:23 PM), http://deadspin.com /infographic-is-your-states-highest-paid-employee-a-co-489635228. The data was derived from media reports and state salary databases.

54 ZIMBALIST, supra note 8, at 137-38. See infra notes 302-03.

55 See, e.g., Frank G. Splitt, Time for Accountability in Sports: Corrupt Collegiate Athletics Overshadow Faltering Academic Mission, NAT'L CATH. REP. (Nov. 14, 2008), http://www.thefreelibrary.com/Time+for+accountability+in+sports\%3A+corrupt +collegiate+athletics. . .-a0189872306; William C. Dowling, College Sports: Faut-il Légaliser la Prostitution?, ACADEMIC QUESTIONS (2001), https://www.rci.rutgers.edu / wcd/prostitu.htm (last visited Mar. 10, 2014); Paul M. Barrett, Carolina Confronts Classroom Corruption as Athletes Fail to Read, BLOOMBERG (Feb. 27, 2014, 3:00 AM), http://www.bloomberg.com/news/2014-02-27/carolina-confronts-classroom-corruption-as -athletes-fail-to-read.html. The current controversy over concussions, and the claim that the NCAA failed to act early enough, is one illustration. Associated Press, Concussion Suit Seeks Class-Action, ESPN.COM (July 20, 2013, 7:53 AM), http://espn.go.com/college -sports/story/_id/9493871/concussion-suit-ncaa-seeks-class-action-status.

56 See supra note 10. The current NCAA president earned more than $\$ 1.7$ million in tax year 2011. Tom Fornelli, NCAA President Mark Emmert Made \$1.7 Million for 2011 Tax Year, CBSSPORTS.COM (July 10, 2013, 1:12 PM), http://www.cbssports.com/college football/eye-on-college-football/22710002/mark-emmert-made-17-million-for-2011-tax -year. Not all commentators believe that a college scholarship and other support provided student-athletes is insufficient quid pro quo for their athletic participation. See Mike 
director, described student-athlete amateurism as administered by the NCAA in the 1980s as a form of "economic tyranny" over studentathletes. ${ }^{57}$ If Byers was right back then, he is even more right now. The questions on the table are: was he?, and is he?

\section{II}

\section{ATHLETIC SPENDING AND STUDENT-ATHLETE BENEFITS}

The NCAA today is a large, national, multi-faceted private association with three divisions. It has nearly 1300 members. ${ }^{58}$ More than 453,000 student-athletes competed in the 2011-12 school year, with just short of 170,000 of them competing in Division I. ${ }^{59}$

All three divisions have bylaws requiring student-athletes to be treated like students who are not athletes. ${ }^{60}$ The three divisions articulate the same overarching principles, including promotion of student-athlete well-being, ${ }^{61}$ sound academic standards, ${ }^{62}$ gender equity, ${ }^{63}$ amateurism, ${ }^{64}$ and eligibility decisions that "place proper emphasis on educational objectives, ... promote competitive equity among institutions, and . . . prevent exploitation of studentathletes." ${ }^{25}$ Although there are association-wide and division-wide

Bianchi, Spurrier, SEC Should Know a College Education is Enough of a Reward for Football Players, ORLANDO SENTINEL (July 27, 2013), http://articles.orlandosentinel.com /2013-07-27/sports/os-mike-bianchi-paying-college-athletes-0728-20130727_1_football -players-college-education-sure-spurrier.

57 BYERS, supra note 2, at 347. Byers also described coining the term "student-athlete" and using the term "team" and not "club," as efforts to combat the threat to amateurism and the push to pay college athletes. Id. at 68-69.

58 See Complaint for Damages, Declaratory Relief, and Jury Demand at 9, NCAA v. Collegiate Licensing Co. \& Elec. Arts, Inc., No. 2013 cv238557 (N.D. Ga. Nov. 4, 2013) [hereinafter Complaint for Damages, Declaratory Relief, and Jury Demand].

59 Gary Brown, NCAA Student-Athlete Participation Hits 450,000, NCAA.ORG (Sept. 19, 2012), http://www.ncaa.org/about/resources/media-center/news/ncaa-student-athlete -participation-hits-450000.

60 NCAA MANUAL, supra note $1, \S 1.3 .1$.

61 Id. $\S 2.2$.

62 Id. $\S 2.5$.

63 Id. $\S 2.3$.

64 Id. § 2.9 .

65 Id. $\S 2.12$. There is also an executive committee of university presidents and chancellors from all three divisions that has general policy-making authority for association-wide issues as they arise. Id. $\S 4.1$. 
policies and bylaws, ${ }^{66} \mathrm{NCAA}$ governance fundamentally is divisioncentric. ${ }^{67}$

Because Division I, and more specifically the FBS, is the lightning rod both for claims that intercollegiate sports are amateur in name only and claims that student-athletes are exploited under the guise of amateurism, our focus in this Article is on Division I bylaws and policies and on Division I institutions and conferences. We focus our econometric model of student-athlete value on FBS football and Division I men's basketball student-athletes because, with rare exception, they are the only student-athletes who might have independent value in their names and likenesses.

\section{A. The Campus}

We doubt that universities ever were pristine, ivy-hung places of teaching and learning divorced from efforts to locate revenues to fund operations. From time immemorial, universities have received government funding and donor contributions. ${ }^{68}$ In these days of less state support, public universities increasingly look to commercial ventures for funding.

Funding sources external to a university are not pernicious simply because they are external. They are pernicious only if universities fail to manage them consistently with their academic mission and the values of higher education. Funding higher education simply through tuition could price universities out of the reach of all but the wealthiest students. Universities therefore generate revenues by giving Pepsi (or Coke) an exclusive campus deal. ${ }^{69}$ They take money from drug manufacturers to research a problem of particular interest

66 See id. $\S 5.02 .1$.

67 Divisions I, II, and III have separate manuals because the divisions have separate, and different, governance and legislative structures. Compare NCAA MANUAL, supra note 1, §§ 4-5, with NCAA, 2013-14 NCAA DIVISION II MANUAL (2014), and NCAA, 2013-14 NCAA DIVISION III MANUAL (2014).

68 Colleges at the great British universities, Oxford and Cambridge, were initially funded by the church or the crown. See, e.g., The History of Christ Church, CHRIST CHURCH (OXFORD), http://www.chch.ox.ac.uk/visiting/history (last updated May 16, 2013) (noting that the Christ Church was originally founded by Cardinal Wolsley); see also The History of the Chapel, KING's COLLEGE (CAMBRIDGE), http://www.kings.cam .ac.uk/chapel/history.html (last visited Mar. 10, 2014) (noting that King Henry VI founded the chapel at King's College).

69 UNL Re-ups Pepsi Contract, UNL News ReleAses (Feb. 27, 2009, 2:00 PM), http://newsroom.unl.edu/releases/2009/02/27/UNL+re-ups+Pepsi+contract. 
to them. They have chaired professorships paid for by donors. ${ }^{70}$ Athletic programs are part of that world.

One difference between campus revenue-producing projects and those of athletic departments may relate to the uncompensated use of students in promotional, commercial, or revenue-producing activities. To the extent that the NCAA, the conferences, or campus athletic departments might do this, however, they hardly would be unique. Way back when we were children, Little League teams already were sponsored by local businesses and children on the teams wore the names of those businesses prominently displayed on their backs (such a use of student-athletes is prohibited under NCAA bylaws). ${ }^{71}$ Without that sponsorship, some Little League teams might have competed without uniforms and with limited equipment, if they competed at all. Today, the major sponsors of Little League Baseball include Honda, Subway, Gatorade, and Hilton HHonors. ${ }^{72}$

Criticism also revolves around the size of the NCAA and FBS athletic department operations as too big to be exempt from federal taxes and also just too big, period. ${ }^{73}$ The federal tax laws do not decide tax-exempt status on the size of net revenues, ${ }^{74}$ however, and some charities are big business. ${ }^{75}$ To be tax-exempt, an educational institution ${ }^{76}$ must show that it is organized ${ }^{77}$ and operated exclusively

70 Two of the three authors of this Article have chaired professorships funded by private donors.

71 See infra notes 129-33 and accompanying text.

72 Erik Spanberg, How Little League Scores Big with Sponsors, STREET \& SMITH'S SPORTS BUS. J., July 1, 2013, at 20, http://www.sportsbusinessdaily.com/Journal/Issues /2013/07/01/In-Depth/Little-League.aspx.

${ }^{73}$ For example, the entire Savannah State athletic department budget is $\$ 200,000$ less than what Texas head football coach Mack Brown made in 2012. Lenn Robbins, Big 5 Conferences Don't Want to Play Smaller FCS Schools, N.Y. POST (July 26, 2013, 4:00 AM), http://nypost.com/2013/07/26/big-5-conferences-dont-want-to-play-smaller-fcs -schools/.

74 The IRS does not use the term "non-profit" for educational institutions.

75 Forbes estimates that in 2011, $\$ 300$ billion was given to 1.2 million nonprofits in the United States. William P. Barrett, The Largest U.S. Charities for 2012, ForBES (Nov. 8, 2012, 5:56 PM), http://www.forbes.com/sites/williampbarrett/2012/11/08/the-largest-u-s -charities-for-2012/. The American Red Cross is listed fifth on Forbes's list of one hundred top revenue-producing charities, with $\$ 3.12$ billion in revenues. Id. In 2011, the American Red Cross had net assets of $\$ 2.2$ billion and total operating expenses of $\$ 3.4$ billion. Brian Rhoas, American Red Cross FY 2011 Financial Results, AM. RED CROss, http://www.redcross.org/about-us/publications/fy11-financials (last visited Mar. 10, 2014).

76 Section 501(c)(3) of the Internal Revenue Code covers most educational institutions. 26 U.S.C. § 501(c)(3) (2012).

77 An educational institution usually satisfies its exclusive organizational purpose through its articles of incorporation and bylaws. 
for educational purposes and that none of its net earnings benefit private individuals or shareholders. ${ }^{78}$

In 2012, the University of Texas football team generated $\$ 163$ million in revenues. ${ }^{79} \mathrm{Big}$, certainly. But these athletic revenues pale in comparison to the nearly $\$ 1.4$ billion in 2012 total operating revenues generated by the University of Texas campus. ${ }^{80}$

The real criticism of athletic department revenues seems to be focused on how the money is spent as well as on the disconnect between NCAA and institutional revenue-producing ventures and the limits imposed on funds and sources of funds available to studentathletes. ${ }^{81}$ There is merit to the claim that athletic departments are out of touch with campus spending. A head coach gets a raise for fear he might bolt to another program. ${ }^{82}$ At the same time, there is a campus salary freeze. Sport support staffs continue to increase, ${ }^{83}$ while faculty

7826 C.F.R. § 1.501(c)(3)-1(c)(1) (2008) (“An organization will be regarded as operated exclusively for one or more exempt purposes only if it engages primarily in activities which accomplish one or more of [the] exempt purposes specified in section 501(c)(3). An organization will not be so regarded if more than an insubstantial part of its activities is not in furtherance of an exempt purpose."). See Church of Scientology of Cal. v. Comm'r, 83 T.C. 381 (1984), aff'd, 823 F.2d 1310 (9th Cir. 1987) (taxpayer was not operated exclusively for an exempt purpose under section 501(c)(3) because taxpayer had a substantial commercial purpose, namely that its net earnings benefited key Scientology officials).

79 Steve Berkowitz et al., Most NCAA Division I Athletic Departments Take Subsidies, USA TODAY (July 1, 2013, 12:48 PM), http://www.usatoday.com/story/sports/college /2013/05/07/ncaa-finances-subsidies/2142443/.

80 Univ. OF TeX. Sys., Operating Budget Summaries, Fiscal Year 2012, at 2 (Aug. 2011), available at http://www.utsystem.edu/cont/reports_publications/summaries $/ 2012 /$ FY2012\%20Budget $\% 20$ Summaries.pdf. Less than one-third of that amount came from tuition and fees.

81 Gregg Doyel, Time To Pay College Football Players-Changing Times, Money Say So, CBSSPORTS.COM (Sept. 25, 2013, 9:39 AM), http://www.cbssports.com/general /writer/gregg-doyel/23838595/its-time-pay-college-football-players-changing-times -money-say-so (comparing Oklahoma football coach salaries and ticket prices from 1950 - when Bud Wilkinson earned fifteen thousand dollars and game day tickets went for less than five dollars - to 2013, when Bob Stoops made $\$ 4.55$ million and tickets sold for as much as $\$ 650$ ).

82 Or he doesn't, and he does. Chris Bahn, Bret Bielema Attracted To Razorbacks By Money Available To Assistant Coaches, ARK. BUS. (Dec. 6, 2012, 9:45 AM), www.arkansasbusiness.com/article/89406/new-coach-attracted-to-razorbacks-by-money -available-to-assistant-coaches.

83 In 2013, the University of Oklahoma added five additional football support positions: director of player personnel, director of sports nutrition, and "quality control" personnel for offense, defense and special teams. John Shinn, OU Football Support Staff Gets A Boost, NORMAN TRANSCRIPT (Aug. 8, 2013), http://normantranscript.com/sports/x1084 949806/OU-football-support-staff-gets-a-boost/print. See Thomas O'Toole, NCAA Cabinet 
positions go unfilled. A state-of-the-art dormitory is built for studentathletes. ${ }^{84}$ A football weight room has Brazilian Ipe wood floors. ${ }^{85}$ Football lockers are equipped with iPads and locker rooms showcase waterfalls. ${ }^{86}$ At the same time, the ceiling in the campus computer lab is falling down. Indeed, if athletic facility projects were evaluated on the same metric as campus projects, we doubt that any athletic facility project at a major FBS school would make the top 100 construction needs on the greater campus.

University intra-campus revenue redistribution is a form of academic socialism where all revenues generated locally are gathered centrally and distributed as needed. By contrast, athletic departments at major FBS universities often are operated as satellite enterprises insulated from campus revenue reallocation and from campus constraints on how revenues are spent. Despite the amount of athletic revenues produced, moreover, when revenue redistribution occurs, it almost always is a one-way street - from the campus to the athletic department. $^{8}$

Even if athletic department revenues were sufficient to cover all athletic department expenses, we still would neither defend nor endorse current athletic spending. The converse is true, however. Even in the FBS, not all athletic departments generate big revenues, ${ }^{88}$

to Discuss Legislation to Limit Coaching Support Staffs, USA TODAY (June 7, 2010, 5:02 PM), http://usatoday30.usatoday.com/sports/college/2010-06-07-coaching-support-staffs N.htm. Larger and larger staffs are not a new phenomenon. In 1958, for example, the Alabama football program had seventeen assistants. BYERS, supra note 2, at 219.

84 Ryan Osborne, Oklahoma Sooners Student-Athletes Begin Moving Into "State-of-theArt” Dorm Sunday, SPORTSDAYDFW (July 28, 2013, 8:23 PM), http://collegesportsblog .dallasnews.com/2013/07/oklahoma-sooners-student-athletes-begin-moving-into-state-of -the-art-dorm-sunday.html/.

85 Landon Hemsley, Commentary: Oregon's New Football Facilities Are Just Too Much, DESERET News (Aug. 2, 2013, 10:40 AM), http://www.deseretnews.com/article /865583946/Commentary-Oregons-new-football-facilities-are-just-too-much.html?pg=all.

86 Brent Yarina, What's In Your Locker? At Nebraska, There's An iPad, BTN.COM (Aug. 30, 2012, 8:02 PM), http://btn.com/2012/08/30/whats-in-your-locker-at-nebraska -theres-an-ipad/; Andrew Gribble, More Than Just Eye Candy, Alabama's New PlayerFriendly Facility Thrives Off 'Functionality', AL.COM (Aug. 2, 2013, 6:52 AM), http://www.al.com/alabamafootball/index.ssf/2013/08/alabama_players_facility.html.

87 Subsidization of athletic departments by the greater campus is not a new phenomenon. Pauley Pavilion at UCLA, for example, was built in 1969 using among other revenues, \$1.5 million in student registration fees; student fees at Indiana, as another example, were used to retire bonds floated to build the football stadium. BYERS, supra note 2 at $221,223$.

88 Troy University, for example had $\$ 16.5$ million in revenues in 2012. John Zenor, Troy in Midst of \$73 Million Athletics Makeover, ASSOCIATED PRESS (May 10, 2013, 3:29 PM), http://collegefootball.ap.org/article/troy-midst-73-million-athletics-makeover. 
and the great majority of them, regardless of total revenues, operate at a deficit. These deficits can run as high \$28 million annually. ${ }^{89}$ USA Today annually collects data on more than 225 Division I college athletic programs at public universities. ${ }^{90}$ In 2012, only seven operated their athletic departments in the black with no subsidy from the greater campus, ${ }^{91}$ and only fourteen more covered expenses with a campus subsidy. ${ }^{92}$ Whether one evaluates spending in the absolute or compared to overall campus spending protocols, FBS athletic spending seems out of control.

\section{B. The Big Money and Where It Goes}

We wonder whether the outrage over athletic department revenues and the concomitant failure to compensate student-athletes would be the same no matter where the revenues landed. Mack Brown, formerly the Texas head football coach, was paid $\$ 5$ million in 2013. ${ }^{93}$ Suppose, instead, that he was paid $\$ 1$ million with no bonuses or side deals. Suppose none of his assistant coaches made more than $\$ 100,000$. Suppose athletic facilities were evaluated in the same manner as all other campus projects. Suppose there was an independent audit and an assessment of the need for a new or upgraded facility, and its appeal to recruits was not a factor that could be considered. Suppose bonds could not be floated to cover new facilities. ${ }^{94}$ Suppose that the University of Texas mirrored Ohio State University and sponsored thirty-seven teams ${ }^{95}$ rather than sixteen. ${ }^{96}$

89 Kelly Heyboer \& Ted Sherman, Rutgers Athletics Ran Nearly \$28 Million Deficit Last Year, Report Shows, NJ.COM (May 14, 2013, 6:41 PM), http://www.nj.com /rutgersfootball/index.ssf/2013/05/rutgers_athletics_ran_28_milli.html.

${ }^{90}$ For a full list of all schools included in the survey, see NCAA Finances, 2012 Total Revenue, USA TODAY, http://www.usatoday.com/sports/college/schools/finances/ (last visited Mar. 27, 2014). Data were acquired through the NCAA and open record requests. Methodology for NCAA Athletic Department Revenue Database, USA TODAY (May 10, 2013, 11:41 AM), http://www.usatoday.com/story/sports/college/2013/05/10/college -athletic-department-revenue-database-methodology/2150123/.

91 These were Nebraska, Texas, Ohio State, Oklahoma, Penn State, Purdue, and LSU. Berkowitz et al., supra note 79 .

$92 \mathrm{Id}$.

93 Associated Press, Brown to Receive \$5M a Season, ESPN.COM (Dec. 10, 2009, 2:06 AM), http://sports.espn.go.com/ncf/news/story?id=4728932.

94 See BYERS, supra note 2, at 221-23.

95 OHIOSTATEBUCKEYS.COM, http://www.ohiostatebuckeys.com/ (last visited Apr. 6, 2014).

96 TEXASSPORTS.COM, http://www.texasssports.com/ (last visited Apr. 6, 2014). 
Suppose all excess Longhorn revenues went back to the greater campus.

If all of this were the case, Texas athletics still would generate big revenues, and those revenues still would go in pockets other than those of student-athletes. Would the cry of mistreatment to football and men's basketball student-athletes still be heard? Or be as strident?

Coach salaries, fancy new facilities, and athletic department spending divorced from campus constraints certainly are one part of the story regarding athletic spending. The other part of the story, largely untold, is the support provided to student-athletes.

A full-ride athletic scholarship covers tuition, room and board, and books. Its value ranges between universities and even between instate and out-of-state students at the same state university. ${ }^{97}$ At Stanford University, for example, a full scholarship is worth more than $\$ 54,500,{ }^{98}$ while at the University of Florida it is worth about $\$ 22,000$ annually for in-state students and $\$ 44,000$ for those from out of state. ${ }^{99}$ Andrew Zimbalist, the Robert A. Woods Professor of Economics at Smith College, evaluated the value of a full-ride academic-year athletic scholarship as equivalent to the salary paid to a minor league baseball player. ${ }^{100}$ In addition to an academic-year scholarship, moreover, student-athletes may receive financial aid to attend summer school. ${ }^{101}$

NCAA bylaws also permit assistance to student-athletes beyond scholarships. Student-athletes may receive full medical care. ${ }^{102}$ They

97 Scholarships are tax-exempt, moreover. 26 U.S.C. $\$ 117$ (2012).

98 Kathleen J. Sullivan, Stanford Raises Undergraduate Tuition 3 Percent for the 201213 School Year, STAN. REP. (Feb. 7, 2012).

99 Bianchi, supra note 56.

100 ZIMBALIST, supra note 8 , at 51 . The total amount spent on scholarships by all NCAA institutions is more than $\$ 2$ billion annually. How Do Athletics Scholarships Work?, NCAA.ORG, http://www.ncaa.org/about/resources/media-center/how-do-athletics -scholarships-work (last visited Mar. 27, 2014). However, minor league baseball players claim they are not even paid the minimum wage required by law. See Cheryl Armstrong, Minor Leaguers Sue Baseball for Low Pay, in Federal Class Action, COURTHOUSE NEwS SERV. (Feb. 11, 2014, 10:24 AM), http://www.courthousenews.com/2014/02/11/65251 .htm.

101 NCAA MANUAL, supra note $1, \S 15.2 .8$

102 Id. $\S 16.4$. This can include drug rehabilitation, insurance costs, expenses that result from permanent disability, travel and actual and necessary expenses for treatment. See NCAA DIVISION I MANUAL FIgURE 14-1. Institutions also must certify that they have insurance coverage for student-athlete athletically related injuries. NCAA MANUAL, supra note $1, \S 3.2 .4 .8$. In addition, student-athletes may receive free legal assistance in NCAA proceedings when their eligibility is at issue or in lawsuits that result from a studentathlete's involvement in practice or competition. Id. $\S$ 16.3.2. 
get tutors and academic counselors free of charge; at the major football programs, tutors are available for all courses in which a student-athlete is enrolled. ${ }^{103}$ If there is an emergency at home, a student-athlete may receive funds to cover expenses. ${ }^{104}$ They also receive team apparel, including shoes. And has anyone checked the price of shoes recently?

Student-athletes may receive athletic funds additional to their scholarships through the NCAA Student Assistance Fund. ${ }^{105}$ During the 2013-14 school year, for example, each student-athlete at the University of Nebraska received $\$ 700$ to help defray car expenses, campus parking permits, cell phone bills, travel expenses, and educational expenses; financially-disadvantaged student-athletes received $\$ 1400 .^{106}$ Notwithstanding their athletic scholarships, which cover board, student-athletes also receive meals when on team travel and when on campus during break times if they are there for team practice or competition. $^{107}$

Athletic departments pay travel costs to competition, travel that is almost always by private charter for football and at least periodically

103 Id. $\S 16.3 .1 .1$.
104 These are processed as pre-approved incidental waivers and include, for example, reimbursement for stolen items. John Infante, Clinton-Dix Loan May Not Have Been Necessary, ATHNET (Oct. 4, 2013), http://www.athleticscholarships.net/2013/10/04 /clinton-dix-loan-may-not-have-been-necessary.htm.

105 NCAA MANUAL, supra note $1, \S \S 15.01 .6 .1,16.11 .8(\mathrm{f})$. Federal funds are also available to students with financial need, over and above a full athletic scholarship. 20 U.S.C. $§ 1070(a)(1)$ (2012). The Pell Grant was established to assist students with financial need to cover the costs of higher education. Id. Students with less than full need receive Pell Grant funds proportionate to their need. Id. There are several federal scholarship funds that are excluded from athletic scholarship computations. NCAA MANUAL, supra note $1, \S \S 15.02 .4 .3,15.2 .5$.

106 In 2013-14, at the University of Nebraska, Pell Grant funds also amounted to \$5645 per student. See also e-mail from Jena Johnson, Assistant Dir. of Compliance for StudentAthlete Servs., Univ. of Neb., to J.R. Potuto, author (Nov. 4, 2013, 12:49 AM) (on file at UNL Law College); e-mail from Jena Johnson, Assistant Dir. of Compliance for StudentAthlete Servs., Univ. of Neb., to J.R. Potuto, author (July 19, 2013, 4:53 PM) (on file at UNL Law College). Additional permissible uses included utility, cell, and cable bills. Id. All scholarship student-athletes received Student Opportunity funds, and non-scholarship student-athletes who were on a team for at least one semester also received $\$ 700$. Id.

107 Among other authorized expenses are funds for transportation, housing and meals for a student-athlete's parents or legal guardians, a spouse, and other student-athletes to be present if a student-athlete suffers from a life-threatening illness or for student-athletes to attend a teammate's funeral, and transportation, hotel, and meal expenses for spouses and children to attend a bowl game or one round of an NCAA championship. NCAA MANUAL, supra note $1, \S \S 16.6 .1 .3,16.6 .1 .1$. 
for other sports. ${ }^{108}$ Athletic facilities for the exclusive use of studentathletes may include academic services facilities, practice facilities, strength and conditioning facilities, and locker rooms. ${ }^{109}$ Stadiums and arenas may have donor suites and other amenities to which student-athletes have no access, but one could hardly say that studentathletes make no use of these facilities overall or derive no benefit from them. There also is economic value to all the other services that universities with major football programs may provide to their student-athletes (all student-athletes, not just football and men's basketball student-athletes). Such services include academic counseling, media relations, nutritionists, dieticians, weight trainers, strength and conditioning specialists, and sports psychologists.

A college education also has economic value (a value not part of the deal for minor league baseball players). The 2012 median weekly salary of a college graduate was $\$ 1066$, more than $\$ 400$ over that of a high school graduate. ${ }^{110}$ The current projected difference in lifetime earnings is $\$ 1$ million. ${ }^{111}$ Contacts made with donors and fans offer lifetime business and professional advantages. ${ }^{112}$

Additional context comes from a comparison of the situation of student-athletes with that of students who are not athletes. Students

108 David Woods, Charter Flights a Benefit of Butler's Evolution into Top Program, USA TODAY (Jan. 23, 2013, 12:29 PM), http://www.usatoday.com/story/sports/ncaab /2013/01/23/butlers-evolution-hoops-team-now-takes-charter-planes-to-games/1858519/; Switch to Big Ten May Change How Nebraska Teams Travel, HuSKERBOARD.COM (July 21, 2010, 3:49 AM), http://www.huskerboard.com/index.php?/topic/44935-switch-to-big -ten-may-change-how-nebraska-teams-travel/; Mary Jane Credeur, Delta Woos Teams With Legroom, Leather as Charters Pad Profit, BloOMBERG (Jan. 5, 2011, 7:37 AM), http://www.bloomberg.com/news/2011-01-05/delta-pampers-teams-with-legroom-snacks -as-charters-pad-profit.html; see also Paul Steinbach, Athletic Departments Rethinking Ways to Make Travel Dollars Go Farther, ATHLETIC BUS. (Oct. 2008), http://www.athleticbusiness.com/Budgeting/athletic-departments-rethinking-ways-to-make -travel-dollars-go-farther.html.

109 Purdue University is one example of a school providing such facilities, and the value of services such as sports information, sports performance, video staff, sports medicine, and academic support is estimated at six thousand dollars annually per studentathlete. E-mail from Morgan J. Burke, Athletic Dir., Purdue University, to Jeffrey T. Bolin, Christie L. Sahley, Mitchell Daniels, and Timothy D. Sands (Sept. 12, 2013, 2:36 PM) (on file in office of J.R. Potuto).

110 Employment Projections, U.S. BUREAU OF LAB. STAT., http://www.bls.gov/emp /ep_chart_001.htm (last updated Dec. 19, 2013) (providing that a high school graduate's median weekly salary was $\$ 654)$.

111 Anthony P. Carnevale et al., Executive Summary, The College Payoff: EDUCATION, OCCUPATIONS, LIFETIME EARNINGS 2 (2011), available at http://www9 .georgetown.edu/grad/gppi/hpi/cew/pdfs/collegepayoff-summary.pdf.

112 See ZiMBALIST, supra note 8, at 53. 
who are not athletes have to pay for services that student-athletes get for free. Tutoring services, for example, can cost anywhere from ten to forty dollars per hour. ${ }^{113}$ As another example, no one provides students who are not athletes with funds if they encounter an emergency. Or for shoes. Two-thirds of college graduates, moreover, had to borrow money to attend college. ${ }^{114}$ The average amount borrowed in 2013 was $\$ 26,600$, while one in ten college students borrowed more than $\$ 40,000$. These students leave college with a substantial debt burden that also includes the accruing interest incurred on the debt. ${ }^{115}$

\section{The NCAA and Student-Athletes}

Student-athletes also receive benefits directly from the NCAA. NCAA revenues cover at least a portion of travel and hotel expenses $^{116}$ for the nearly fifty thousand student-athletes ${ }^{117}$ who annually compete in the eighty-nine NCAA championships ${ }^{118}$ (and preliminary rounds), and also the costs of administering the championships. They fund postgraduate scholarships, as well as education and leadership programs for student-athletes in all three divisions. ${ }^{119}$ There are degree-completion funds available for studentathletes who have exhausted eligibility but have not yet graduated. ${ }^{120}$ Finally, revenues are distributed back to the conferences and campuses, and form part of the budgets used by them to fund their operations.

113 Information about the cost of tutors comes from discussion with students who avail themselves of tutors.

114 Chris Denhart, How The \$1.2 Trillion College Debt Crisis is Crippling Students, Parents and the Economy, FORBES (Aug. 7, 2013, 12:30 PM), http://www.forbes.com /sites/specialfeatures/2013/08/07/how-the-college-debt-is-crippling-students-parents-and -the-economy/.

115 Id.

116 NCAA MANUAL, supra note $1, \S 31.4 .6$.

117 Championships, NCAA.ORG, http://www.ncaa.org/about/what-we-do/champion ships (last visited Mar. 9, 2014).

118 NCAA MANUAL, supra note $1, \S 18.3$.

119 See NCAA, Student-Athlete Affairs Program Descriptions (Sept. 9, 2011) (on file in office of J.R. Potuto).

120 See NCAA, Division I Degree COMPletion AwARD, APPlicAtion FOR FALL/SPRING 2014-15 (2014), available at http://www.ncaa.org/sites/default/files/D1_DC _APP_FS_2014_15_FORM.pdf. The funds are limited, however. 
III

\section{NCAA AMATEURISM BYLAWS}

NCAA bylaws limit NCAA, conference, and university commercial or promotional uses of student-athletes, including their names and likenesses. NCAA bylaws also prohibit student-athletes from deriving revenues from any commercial or promotional uses.

\section{A. Student-Athletes}

NCAA bylaws prohibit student-athletes from capitalizing on their athletic talent and reputation in two general categories. ${ }^{121}$ The first category prohibits student-athletes from professionalizing themselves by pay for play, ${ }^{122}$ including receiving cash or cash equivalent awards for athletic participation; ${ }^{123}$ competing, even unpaid, on professional teams or with professional athletes; ${ }^{124}$ and hiring agents to negotiate with professional teams. ${ }^{125}$ The second category prohibits studentathletes from making money from their athletic ability or reputation. ${ }^{126}$ These NCAA bylaws prohibit student-athletes from sharing in any NCAA, conference, or institutional revenues that are generated by the use of their names and likenesses. ${ }^{127}$ They also

121 See NCAA MANUAL, supra note $1, \S 12$.

122 Id. $\S \S 12.1 .2(\mathrm{c})-(\mathrm{d}),(\mathrm{g})$. Also included in this category is payment based on athletic ability, entering a professional draft, and accepting a promise when still a student-athlete for pay when no longer a student-athlete. Id. $\S \S 12.1 .2(\mathrm{a})-(\mathrm{c})$, (e)-(f). Pay includes bonuses, a percentage of game receipts, preferential treatment based on athletic ability or reputation, reimbursement for actual and necessary expenses when related to performance, and provision of funds for educational expenses when based on athletic ability and provided by an entity other than a national Olympic Committee pursuant to its Operation Gold program. Id. $\S \S 12.1 .2 .1 .2,12.1 .2 .1 .3,12.1 .2 .1 .5,12.1 .2 .1 .6$. A student-athlete may receive an award (e.g., a trophy or medal) based on performance in "outside" non-NCAA competition, however. Id. $\S 12.1 .2 .1 .5 .2$. A student may also obtain insurance based on future earnings potential. Id. $\S$ 12.1.2.4.4. In addition, a student-athlete may simultaneously be a professional in a sport in which he does not compete in college and yet be an amateur in a sport in which he does compete. Id. $\S 12.1 .3$. This area of amateurism is a patchwork reflecting a balancing of equities in the particular. Combined with other areas of amateurism, the entirety provides no golden thread of amateurism easy to discern and to explain.

123 Id. $\S 12.1 .2 .1 .4 .1$.

124 Id. $\S 12.2 .3 .2$.

125 Id. $\S \S 12.3 .1,12.3 .2,12.3 .3$.

126 Id. $\S 12.3 .1$.

127 Id. § 12.5.1.1(e). 
prohibit student-athletes from making their own deals or from hiring agents to negotiate deals for them. ${ }^{128}$

\section{B. NCAA, Conferences, and Universities}

NCAA bylaws ${ }^{129}$ prohibit the use of student-athletes to promote the commercial activities of a for-profit enterprise, ${ }^{130}$ sales of merchandise that have the name or likeness of individual studentathletes on them, ${ }^{131}$ and sales of printed promotional material (e.g., calendars or posters) that have the name or likeness of an individual student-athlete on them when they also include logos or other corporate marks that may be identified with a sponsor. ${ }^{132}$ Although an institution may sell commercial items with the names or likenesses of teams or other student-athlete cohorts, it may do so only on campus or at its own off-campus outlets when profits go directly to the institution itself. $^{133}$

NCAA bylaws oblige institutions and conferences to include language binding contract partners to adhere to NCAA bylaws, policies, and interpretations involving the use of student-athlete names or likenesses when the subject matter of the contract suggests such use might be possible. ${ }^{134}$ A commercial entity that acts on its own to market the name or likeness of a student-athlete will receive a letter from that student-athlete's university requesting that it cease

128 Id. $\S 12.3 .1$. Student-athletes also may not sell equipment in their sport if their name or likeness is used or if their athletic reputations are used to push sales. Id. § 12.4.2.3.

129 NCAA bylaws explicitly limit institutional uses of student-athletes in promotions. They also limit the NCAA and conferences, although there is no explicit bylaw language saying so. First, the only explicit authorization afforded the NCAA and conferences to use student-athletes in promotions is set forth in NCAA Bylaws 12.5.1.1.1 and 12.5.8. If explicit authorization were not necessary, then those bylaws would be surplusage. Second, the amateurism principle applies to treatment of student-athletes; for amateurism purposes, that treatment does not change because the activity is sponsored by the NCAA or conference rather than an institution.

${ }^{130}$ Id. $\S 12.5 .1 .1(\mathrm{~g})$.

${ }^{131}$ Id. $\S 12.5 .1 .1(\mathrm{~h})$. However, informational items such as media guides and institutional publications may be sold.

132 Id. $\S 12.5 .1 .1(\mathrm{c})$.

133 Id. $\S$ 12.5.1.1(e), (h).

134 Id. $\S \S 3.2 .4 .18 .1$, 3.3.4.7.1; see also THE NCAA's ADVERTISING AND PROMOTIONAL STANDARDS CURRENT 2012-13, available at http://i.turner.ncaa.com/dr /ncaa/ncaa/release/sites/default/files/files/Advertising_Promotional_Standards.pdf. 
and desist, ${ }^{135}$ as doing so violates NCAA bylaws ${ }^{136}$ and threatens the student-athlete's eligibility. ${ }^{137}$

The prohibition against NCAA, conference, and university use of a student-athlete's name and likeness in promotional activities describes a narrow area in which these activities are permissible. ${ }^{138}$ Administering team championships is the central role played by any sports governing body, amateur or professional. NCAA bylaws authorize NCAA and conference use of a student-athlete's name and

135 Typically entities comply. If an entity is a booster of an athletic department, the department can disassociate the entity for noncompliance. NCAA MANUAL, supra note 1, $\S 19.5 .2 .4$. If an entity is not a booster and refuses to comply, then the only option is a lawsuit brought on behalf of the student-athlete. Clay Travis, Johnny Manziel Opens Massive Loophole in Paying Players Rule, Fox C. FootBAll Blog (Feb. 25, 2013), $\mathrm{http} / / / \mathrm{msn}$.foxsports.com/college-football/outkick-the-coverage/johnny-manziel-opens -massive-loophole-in-paying-players-rule.php.

136 NCAA MANUAL, supra note $1, \S$ 12.5.2.2.

137 A typical cease and desist letter reads as follows:

This correspondence is in regard to the [insert commercial use] including the likeness of [insert university name] student-athlete [insert student-athlete name] that you are selling on your website. Please find a photograph of the item in question attached. NCAA bylaw 12.5.2.2 below prohibits a commercial agency from selling commercial items that include a student-athlete's name, image, or likeness. Therefore, your selling [insert item] including [insert student-athlete's name]'s likeness is impermissible.

12.5.2.2 Use of a Student-Athlete's Name or Picture without Knowledge or Permission: If a student-athlete's name or picture appears on commercial items (e.g., T-shirts, sweatshirts, serving trays, playing cards, posters) or is used to promote a commercial product sold by an individual or agency without the student-athlete's knowledge or permission, the student-athlete (or the institution acting on behalf of the student-athlete) is required to take steps to stop such an activity in order to retain his or her eligibility for intercollegiate athletics.

The University requests that you permanently cease selling the [insert item]. In addition, we ask that you refrain from using the names, images, or likenesses of any of our student-athletes on future commercial items and in any future promotions or advertisements. Failure to comply with these requests places the eligibility of the student-athletes in jeopardy. Please respond in writing that you have received this email and that you have stopped selling the [insert item] and any other commercial items containing the names, images, or likenesses of any of our current student-athletes.

Sincerely,

Compliance Department

138 NCAA MANUAL, supra note $1, \S 3.2 .4 .18 .1$ (explaining how institutions may use student-athletes' name and likeness); id. $\S 3.3 .4 .7 .1$ (explaining how institutions and conferences are required to include in all commercial agreements involving student-athlete names and likenesses, NCAA language binding a commercial entity to NCAA bylaws, interpretations, and policies on the permissible scope of licensing and marketing agreements language). One general restriction is that student-athlete personal appearances may not involve missed class time. Id. $§$ 12.5.1.1(d). 
likeness to promote, respectively, $\mathrm{NCAA}^{139}$ and conference championships. ${ }^{140}$

In addition, institutions more generally may use student-athlete names and likenesses to support educational activities and activities "incidental to the student-athlete's participation in intercollegiate athletics," 141 while the NCAA may use student-athlete names and likenesses to promote NCAA "events, activities or programs." These activities and events may generate revenues through corporate sponsorships, but the only permitted evidence of sponsorship is the inclusion of a trademark or logo, together with address information on printed promotional materials. ${ }^{143}$

There is no restriction on sales of merchandise that include neither a student-athlete's name nor likeness but nonetheless might be closely identified with a particular student-athlete. The most obvious example is a team jersey with a number on it. When a player is particularly talented, particularly successful athletically, or has a particularly compelling back-story that captures the affection of fans, the jersey number may be identified with him long after he stops playing competitively. ${ }^{144}$ Universities select the particular numbers to be used on jerseys that are sold. These presumably relate to which player

139 Id. $\S \S 12.5 .1 .1 .1,12.5 .1 .8$. The NCAA also may engage a third party to act on its behalf to handle promotions. Third parties include athletic conferences, institutions hosting the activity, and local organizing committees. Id. NCAA bylaws also permit an Olympic or national team's governing body to use a student-athlete's name or likeness on team trading cards so long as the student-athlete is a member of the team and all revenues from the sale are deposited directly with that Olympic or national team. Id. $\S 12.5 .1 .1 .4 .1$.

140 Id. $\S 12.5 .1 .8$. Conference merchandise sales using an individual student-athlete's name or likeness are limited to posters produced by the conference or a member institution. Id.

${ }^{141}$ Id. $\S 12.5$.1.1. Noninstitutional charitable and other nonprofit agencies, with athletic department permission, also may use student-athletes and their names and likenesses in promotions to support their charitable or non-profit activities. The same restrictions apply to them as apply to institutions - sales of merchandise only at official outlets; evidence of commercial entity involvement limited to logos, trademarks, and address information; all revenues directly to the nonprofit; no commercial activities of a nonprofit may be promoted; no depictions of individual student-athletes, their names and likenesses, except for items such as media guides. Conferences are similarly restricted.

142 Id. $\S 12.5 .1 .1 .1$.

143 Id. § 12.5.1.1(b).

144 An example is the New York Yankees' Mickey Mantle and the number seven. In some cases - again, Mickey Mantle is an example - the uniform number may even be permanently retired. 
numbers are expected to generate the most sales. ${ }^{145}$ Related to the general question of valuing student-athlete names and likenesses, the unanswered question here is whether putting numbers on jerseys increases overall jersey sales, or only the distribution of sales.

\section{IV \\ KELLER/O’BANNON LITIGATION}

Sam Keller played college football at Arizona State University and then the University of Nebraska. ${ }^{146}$ He sued the NCAA, claiming infringement of a right of publicity on his behalf and on behalf of other former football and men's basketball student-athletes ${ }^{147}$ arising out of an exclusive license granted by the NCAA to Electronic Arts, Inc. (EA Sports) to market football and men's basketball video games using the NCAA's name and logo. ${ }^{148}$ These EA Sports video games used avatars that were easily recognizable as actual players on the university teams for which they competed and were named as those players through use of a readily accessible computer application that complemented the game. ${ }^{149}$

Ed O'Bannon played basketball at UCLA. ${ }^{150}$ He sued the NCAA on behalf of himself and other former football and men's basketball student-athletes, claiming that the NCAA offends the antitrust laws

145 Bob Hertzel, Numbers Play Vital Role When Buying Jerseys, TimesWV.com (July 12, 2013), http://www.timeswv.com/wvu_sports/x1952120496/HERTZEL-COLUMN -Numbers-play-vital-role-when-buying-jerseys. It is said that at West Virginia University, for example, the back of the jersey may not say "“Austin' [Tavon Austin, star wide receiver and eighth pick in 2013 NFL draft] or 'Smith,'[Geno Smith, star quarterback and second round pick in the $2013 \mathrm{NFL}$ draft] but in the mind of the fan it is his tribute to that player," and that "[a] No. 5 jersey is going to be a Patrick White [star quarterback and second round pick in the 2009 NFL draft] jersey, almost no matter to whom it is assigned that season." Id.

146 See Sam Keller Bio, HUSKERS.COM, http://www.huskers.com/ViewArticle.dbml ?ATCLID=866801 (last visited Mar. 10, 2014).

147 The other named plaintiffs were Bryan Cummings, Lamar Watkins, and Byron Bishop. Third Consolidated Amended Class Action Complaint at 2, In re NCAA StudentAthlete Name \& Likeness Licensing Litig., No.4:09cv01967, 2013 WL 3772677 (N.D. Cal. July 18, 2013) [hereinafter Third Consolidated Amended Class Action Complaint]. Keller also sought class certification.

148 Student-Athlete Likeness Lawsuit Timeline, NCAA.ORG (Dec. 12, 2013), http://www.ncaa.org/about/resources/media-center/press-releases/student-athlete-likeness -lawsuit-timeline.

149 Third Consolidated Amended Class Action Complaint, supra note 147, at 3, 15273.

150 See History and Records, UCLA BASKETBALL, http://members.tripod.com/ucla _hoops/Bruin\%20History.htm (last visited Mar. 27, 2014). 
when it prevents players from exploiting their right of publicity through group licensing arrangements with videogame developers and broadcasters. $^{151}$

In the resultant, consolidated Keller/O'Bannon lawsuit, current and former football and men's basketball student-athletes challenge the uncompensated use of their names and likenesses under both a right of publicity and the antitrust laws, focused particularly on the EA Sports videogames (right of publicity plaintiffs) and videogames and game broadcasts (antitrust plaintiffs). ${ }^{152}$ A subclass of the antitrust plaintiffs was certified as a class action for injunctive relief while certification of the damages subclass was denied. ${ }^{153}$

\section{A. Legal Claims, in General and in Brief}

Our discussion of the lawsuit brought by Keller and O'Bannon is not intended to be a close and detailed analysis of the merits. Instead, we provide a brief rendition of the contours of the legal claims and available defenses as context for our discussion of the collegiate model of athletics.

The Keller/O'Bannon antitrust claim is that through its member universities, the NCAA combined in restraint of trade to restrict the opportunity for players to enter into group licensing arrangements to profit from their rights of publicity. ${ }^{154}$ This claim is derivative of the right of publicity claim. If there is no violation of a right of publicity,

151 Order Granting in Part and Denying in Part Motion for Class Certification at 2, In re NCAA Student-Athlete Name \& Likeness Licensing Litig., No. C 09-1967CW (N.D. Cal. Nov. 8, 2013) [hereinafter Class Certification Order].

152 Keller and O'Bannon were not the only former student-athletes to sue. A right of publicity lawsuit was brought in New Jersey (Hart v. Electronic Arts, 717 F.3d 14 (3d Cir. 2013)) and in West Virginia (Complaint, Alston v. Electronic Arts, 2013 WL 4799103). See also Complaint for Damages, Declaratory Relief, and Jury Demand, supra note 58. Should the plaintiffs prevail, other merchandising and commercial activities likely subject to these same claims would include archived game broadcasts on the NCAA on-demand website, game re-telecasts on ESPN Classic, and sales of team and individual photographs and game video clips.

153 Class Certification Order, supra note 151. The injunctive subclass (and what would have been the damages subclass) is comprised of current and former Division I football and men's basketball student-athletes.

154 The statutory genesis of federal antitrust claims is the Sherman Anti-Trust Act. 15 U.S.C. $\S \S 1-2$ (2012). Plaintiffs claim a violation of $\S 1$, which makes it a violation for entities with requisite market share to contract, combine or conspire to restrain trade or commerce. See Washington v. NFL Ventures, 880 F. Supp. 2d 1004 (D. Minn. 2012) (holding that former NFL players failed to state antitrust claim in allegation that the NFL monopolized the market in game footage). 
then the antitrust claim falls of its own weight. If the right of publicity claim is viable, the antitrust plaintiffs then will need to prove that there is an injury to competition in a relevant market in which the NCAA has a sufficient market share to trigger antitrust injury. ${ }^{155}$

The right of publicity derives from the right of privacy. ${ }^{156}$ Its scope is determined by state law. ${ }^{157}$ In general terms, the right of publicity embodies an individual's right to control the use of his name or likeness from commercial exploitation.

The right of publicity is subject to First Amendment defenses. The First Amendment calculus, very generally, balances the similarity and degree of use of an individual's name and likeness with the ideas, expressive content, or artistic creativity contributed by the individual or entity that used the name or likeness. Although the commercial use of an individual's name or likeness is a relevant consideration in determining whether a right of publicity has been breached, First Amendment protection is not defeated simply because the individual who uses another's name and likeness made money from it.

An individual cannot claim a right of publicity if her name or picture is used in a news story even though newspapers are profitmaking, or at least aspire to be. ${ }^{158}$ Equally, Joe DiMaggio could not have prevailed had he claimed a share of royalties from Simon and Garfunkel's lyrics in their song, ${ }^{159}$ "Mrs. Robinson,"160 that say "Where have you gone, Joe DiMaggio, our nation turns its lonely eyes to you." The First Amendment also may insulate an author from a right of publicity claim arising out of a fictionalized account of a

155 See, e.g., Arizona v. Maricopa City Med. Soc'y, 457 U.S. 332 (1982); Chicago Bd. of Trade v. United States, 246 U.S. 231 (1918). The plaintiffs claim injury in two markets: the student-athlete, Division I college education market and the market for student-athlete group licensing rights. Class Certification Order, supra note 151, at 2.

156 See generally Zacchini v. Scripps-Howard Broad. Co., 433 U.S. 562 (1977); J. THOMAS MCCARTHY, THE RightS OF PubliCiTY AND PRIVACY § 1.5[d] (2d ed. 2000); William L. Prosser, Privacy, 48 CALIF. L. REV. 383 (1960).

157 See, e.g., Haelan Laboratories, Inc. v. Topps Chewing Gum, Inc., 202 F.2d 866 (2d Cir. 1953), cert. denied, 346 U.S. 816 (1953). See generally J. Gordon Hylton, Baseball Cards and the Birth of the Right of Publicity: The Curious Case of Haelan Laboratories v. Topps Chewing Gum, 12 MARQ. SPORTS L. REV. 273 (2001).

158 See, e.g., Cher v. Forum Int'l, Ltd., 692 F.2d 634 (9th Cir.), cert. denied, 462 U.S. 1120 (1983); Hoffman v. Capital Cities/ABC, Inc., 255 F.3d 1180 (9th Cir. 2001).

159 Joe DiMaggio is a Hall of Fame centerfielder who played for the New York Yankees in the 1940s through the mid-1950s.

160 The Graduate (Embassy Pictures Co. 1967). DiMaggio also could not have prevailed against the producers of the movie, The Graduate, for their use of the song in the film. 
real person or an unauthorized biography. ${ }^{161}$ On the other hand, Joe DiMaggio would prevail against a manufacturer who sold T-shirts silk-screened with DiMaggio's face. ${ }^{162}$

\section{B. EA Sports Videogames}

EA Sports has ceased production of NCAA Football. ${ }^{163}$ More recently, it announced a settlement with Sam Keller and his plaintiff class. ${ }^{164}$ The settlement was no surprise, given that EA Sports' claim that its videogames were entitled to First Amendment protection was rejected by two federal circuit courts. ${ }^{165}$ Although videogames are not per se outside of First Amendment protection, the EA Sports games did not constitute creative transformation sufficient to trigger First Amendment protection in that the player avatars looked just like actual players and engaged digitally on the same teams, and in the very activity in which the actual players engaged.

There are unsettled issues arising out of the EA Sports settlement. ${ }^{166}$ Prime among them is how the NCAA will respond if the settlement approved by the federal judge, Claudia Wilken, provides that money is to be distributed to current student-athletes. On the one hand, this money looks much like payment for use of their

161 See, e.g., Rosemont Enters., Inc. v. Random House, Inc., 294 N.Y.S.2d 122 (N.Y. Sup. Ct. 1968), aff'd, 301 N.Y.S.2d 948 (N.Y. App. Div. 1969).

162 This assumes that Joe DiMaggio, and not his estate, brought suit. In many jurisdictions a right of publicity does not survive the death of the individual whose right it is. See, e.g., Lugosi v. Universal Pictures, 603 P.2d 425 (Cal. 1979). See Groucho Marx Prod., Inc. v. Day and Night Co., 523 F. Supp. 485, 490 (S.D.N.Y. 1981).

163 Jerry Hinnen, NCAA Declines to Renew Contract with EA Sports, CBSSPORTS.COM (July 17, 2013, 2:52 PM), http://www.cbssports.com/collegefootball/eye-on-college -football/22796985/ncaa-declines-to-renew-contract-with-ea-sports. Presumably, the settlement also includes NCAA Basketball, as the issues are the same for both games.

164 Complaint for Damages, Declaratory Relief, and Jury Demand, supra note 58.

165 In re NCAA Student-Athlete Name \& Likeness Licensing Litigation, 724 F.3d 1268 (9th Cir. 2013); Hart v. Elec. Arts, Inc., 717 F.3d 141 (3d Cir. 2013). On January 13, 2014, the Supreme Court denied the NCAA's motion for leave to intervene to file a petition for writ of certiorari. NCAA v. Keller, 134 S.Ct. 980 (Mem.) (2014). The NCAA sought Supreme Court review of the lower court decisions that the first amendment did not insulate the EA Sports video game from student-athlete right of publicity claims.

166 Universities and conferences also licensed to EA Sports the right to use their marks and names in the EA Sports videogames. Both the NCAA and most of the universities and conferences interacted with EA Sports through their licensing agent, Collegiate Licensing Company (CLC). One issue relates to the legal position of the universities and CLC over contract revenues that they expected to receive through sale of the videogame. Another issue is whether EA Sports will seek to have CLC contribute to the damages it pays. And, in turn, whether CLC will seek contribution from its clients, the universities. 
names and likenesses, a payment prohibited under NCAA bylaws. On the other hand, the payment is in settlement of a legal claim the players have. ${ }^{167}$

We expect that the NCAA will resolve this matter, should it arise, in the way it handled a lawsuit brought by Johnny Manziel, the Texas A\&M 2012 Heisman-winning quarterback. Manziel sued an individual for selling "Johnny Football" T-shirts while he was still competing at A\&M. ${ }^{168}$ The NCAA said that Manziel could protect his legal rights by suing and that he also was entitled to any damage award, so long as the lawsuit was a bona fide, arms-length dispute and not a sweetheart deal between Manziel and the defendant calculated to circumvent NCAA amateurism rules.

The NCAA is still a defendant in the Keller lawsuit. To prevail against the NCAA regarding the EA Sports videogame, Keller will need to show that, in licensing its name and logo for use in the game, the NCAA was complicit with EA Sports, such that EA Sports' violation of his right of publicity makes the NCAA liable too.

Should the NCAA be found to be liable, however, the intercollegiate athletic world would not implode. The NCAA already has announced that it will no longer license its name and logo for use in the game. ${ }^{169}$ And, EA Sports already has ceased production. ${ }^{170}$

More fundamentally, the NCAA also could refrain from all the ancillary marketing activities that the Keller/O'Bannon plaintiffs describe in their complaint-game highlight films; archived broadcasts; DVDs of famous games; photographs of players taken during the games - and the intercollegiate athletic world still would not implode. Per contra, the result would be that NCAA operations would be more fully consonant with the collegiate model.

\section{Broadcast Rights}

The claim that current student-athletes should be paid a percentage of revenues from television broadcasts of games in which they

167 In any event, any amount paid to student-athletes would be income to the studentathletes under 26 U.S.C. $\S 61(a)$ (2012). Such payments would not be damages for "personal physical injury" within the meaning of 26 U.S.C. § 104(a)(2) (2012).

168 Travis, supra note 135.

169 Darren Rovell, EA Sports Settles With Ex-Players, ESPN.COM (Sept. 26, 2013, 9:23 PM), http://espn.go.com/college-football/story/_id/9728042/ea-sports-stop-producing -college-football-game.

170 Id. 
participate is a new entry in the name and likeness debate. ${ }^{171} \mathrm{We}$ know of no state court that has found a right of publicity in a player to receive name and likeness revenues from an appearance in a televised game.

To date, right of publicity cases have involved professional athletes and entertainers. With regard to these professionals, the courts have found that, through their contracts of employment, they consent to dissemination of their performances (games). ${ }^{172}$ Student-athletes may be said to provide consent through their annual signed authorizations on the "student-athlete statement" 173 for the NCAA, or a third party acting on its behalf, ${ }^{174}$ to use their names or likenesses to promote NCAA championships, events, activities, and programs; and for their universities and conferences to make use of their names and likenesses. ${ }^{175}$ The question is whether student-athletes execute the authorizations knowingly and voluntarily. ${ }^{176}$

Whatever the resolution of the validity of student-athlete consent, however, the critical obstacle to their right of publicity claim is the

171 Because the claim to entitlement to broadcast revenues was not part of the original complaint that O'Bannon filed, the trial judge granted the NCAA the opportunity to redepose three of the plaintiffs. See Jon Solomon, NCAA Allowed to Depose 3 Ed O'Bannon Plaintiffs Again, Including Tyrone Prothro, AL.COM (Feb. 11, 2014, 8:32 AM), http://www.al.com/sports/index.ssf/2014/02/ncaa_allowed_to_depose_3_ed_ob.html.

172 E.g., Baltimore Orioles, Inc. v. Major League Players Ass'n, 805 F.2d 663, 670-73 (7th Cir. 1986); Toney v. L'Oreal, 384 F.3d 486 (7th Cir. 2004).

173 See NCAA MANUAL, supra note 1, § 3.2.4.6 (Student-Athlete Statement); id. § 14.1.3.1 (Student-Athlete Statement; Content and Purpose); id. § 30.12 (Student-Athlete Statement); NCAA Form 12-3a, Student-Athlete Statement-NCAA Division I. There are seven parts to the Statement. In addition to authorizing use of their names and likenesses, student-athletes also sign a Buckley Amendment consent form; affirm their eligibility as amateurs; affirm that they have not tested positive on any drug test administered by national or international sports entities; affirm neither involvement in NCAA rules violation(s) nor knowledge of violations at the student-athlete's university no matter who committed them; and, for student-athletes matriculating to an NCAA institution for the first time, affirm that information provided to the NCAA Eligibility Center and a university's admissions office was valid and accurate, including ACT or SAT scores, high school attendance, completion of coursework and high school grades. Before signing the form, student-athletes are directed to review a summary of NCAA regulations or pertinent NCAA bylaws (the form references NCAA Bylaw Chapters 10, 12, 13, 14, 15, 16, and Bylaws 18.4 and 31.2.3).

174 These include a university that hosts an NCAA championship, a Conference, and a site committee that organizes and administers a championship on site.

175 Samples of an institutional and conference consent form are on file in the office of J.R. Potuto, UNL Law College.

176 Another question, likely relevant to the EA Sports videogame, is whether the language in the authorizations is sufficiently comprehensive to cover videogames. 
application of federal copyright law. ${ }^{177}$ Copyright protection attaches to a creative work fixed in tangible form. ${ }^{178} \mathrm{~A}$ game, as it is played, does not meet that criterion. But the game also simultaneously is broadcast, and broadcasts may be copyrighted. ${ }^{179}$ Copyright rights preempt a state right of publicity, assuming a state would find one in the circumstances. Because the game played is simultaneous with the game broadcast, the courts have held that the two cannot feasibly be separated and, therefore, that federal copyright preempts a right of publicity for both. ${ }^{180}$ In addition, the courts also have held that if a particular use of name and likeness - say in broadcasting a gamedoes not violate an individual's right of publicity, then there also is no violation of the right of publicity in using the individual's name or likeness to promote the game. ${ }^{181}$

Consider now the claim that the NCAA, through its member universities, offends the antitrust laws by combining in restraint of trade to restrict the opportunity for players to enter into group licensing arrangements to profit from their right of publicity. As noted, a necessary precondition for success on this claim is that the plaintiffs have a legally cognizable right of publicity in game broadcasts. Assuming that they do, the plaintiffs still will need to prove antitrust injury, in other words, economic injury to competition, not competitors. Whether the plaintiffs can show injury to competition arising out of restrictions on a market for group licensing deals remains to be seen.

If the plaintiffs were to prevail against the NCAA on a straight right of publicity ground, then football revenues managed at the conference and institutional level would be next up for division. Antitrust violations depend on market share. If the plaintiffs were to prevail on antitrust grounds, therefore, the judgment of its own force is much less likely to trigger changes in conference operations or

17717 U.S.C. $\$ 101$ et seq. (2012).

178 Id. To be copyrightable, a work fixed in tangible form must be original and show creativity. See generally M. NIMMER, NIMMER ON COPYRIGHT § 2.01 (1985) [hereinafter NIMMER].

179 E.g., L. Batlin \& Son, Inc. v. Snyder, 536 F.2d 486, 490 (2d Cir.) (en banc), cert. denied, 429 U.S. 857 (1976). See generally NIMMER, supra note 178, § 2.01.

180 E.g., Baltimore Orioles, Inc. v. Major League Baseball Players Ass'n, 805 F.2d 663 (7th Cir. 1986); Namath v. Sports Illustrated, 371 N.Y.S.2d 10 (N.Y. App. Div. 1975), aff'd, 352 N.E.2d 584 (N.Y. 1976).

181 E.g., Cher v. Forum Int'l Ltd., 692 F.2d 634 (9th Cir. 1982), cert. denied, 462 U.S. 1120 (1983) 
revenue distribution and would have none on institutions. Whether public pressure would push voluntary change is a different story.

\section{Financial Consequences}

The NCAA Division I men's basketball tournament will generate nearly $\$ 11$ billion over its fourteen-year run. ${ }^{182}$ Upwards of ninety percent of all NCAA revenues come from the sale of broadcast and affiliated rights for the Tournament. ${ }^{183}$ Out of these revenues, the NCAA not only funds programs that directly advantage studentathletes, but it handles membership services; enforcement/infractions and student-athlete reinstatement cases; provides staff support and also covers expenses for all meetings of boards, councils, cabinets, and committees; ${ }^{184}$ funds national office staff salaries and expenses; and operates the Eligibility Center, which certifies eligibility for domestic and international prospects on academic and amateurism grounds. ${ }^{185}$

As previously noted, the FBS football championship television deal is worth $\$ 470$ million annually to the FBS conferences, and payouts to their member institutions from the five major conferences-Big Ten, SEC, Pac 12, Big 12, and ACC - in some cases already exceed $\$ 26$ million. The conference money comes primarily from television deals. ${ }^{186}$

182 Thomas O'Toole, NCAA Reaches 14-Year Deal With CBS/Turner for Men's Basketball Tournament, Which Expands to 68 Teams for Now, USA TODAY (Apr. 22, 2010, 4:09 PM), http://content.usatoday.com/communities/campusrivalry/post/2010/04 /ncaa-reaches-14-year-deal-with-cbsturner/1\#.Uxg0Ujn_RUQ. The advent of television not only has had a marked effect on athletic department and NCAA revenues, but it, and airplane travel, have translated the fan interest in college sports from local teams and local competition to a national fan base. BYERS, supra note 2, at 93.

183 Third Consolidated Amended Class Action Complaint, supra note 147, at 77. Big television deals not only are commercial in themselves but they also have commercial consequences. The NCAA agreed to more commercial breaks during telecasts of the men's basketball tournament as part of the quid pro quo for the extra contract money. BYERS, supra note 2 , at 269 .

184 NCAA MANUAL, supra note $1, \S 31.7 .2$.

185 Id. $\S 4.01 .2 .2$. They are the source of the campus Student-Athlete Opportunity Fund, for example. As noted previously, revenues from the Tournament also are distributed back to the conferences and, through them, to the campuses, and form part of the budgets used by them to fund their operations. For a schematic that describes NCAA revenue distribution, see NCAA 2012-13 FinANCIAL UPDATE, DI LEADERSHIP COUNCIL SUPPLEMENT NO.6 (Apr. 2013).

186 See generally NCAA 2012-13 FinANCIAL UPDATE, supra note 185; Potuto, supra note 34 , at 311 . 


\section{More than Financial-the Collegiate Mark and the Slippery Slope}

Compensating student-athletes for the value of their names and likenesses is not pay for play. It also is different in kind from providing an athletic scholarship to cover the full cost of a college education. At least in theory, name and likeness compensation need not mean that the collegiate model will be irreparably harmed and that the wall of amateurism will come tumbling down. In practice, the "law" of unforeseen (unintended) circumstances is the elephant in the room. Every chink in the wall of amateurism leaves the structure less clear, less sound, and more difficult to defend as a coherent whole. Even if pay for play is not the end result, campus treatment of student-athletes may very well change, and in ways that undercut even more what should be the academic primacy of college athletics.

Jim Delany, the Big Ten Conference Commissioner, suggested that pay for play, or a model that provides student-athletes with fifty percent of television revenues rather than outright salaries, might lead Big Ten universities to "downsize the scope, breadth and activity of their athletic programs," perhaps even moving to NCAA Division III, where athletic scholarships are not provided. ${ }^{187}$ His concern was neither exclusively nor primarily focused on lost revenues.

The very fact that student-athletes share revenues from commercial and promotional licensing ventures might impel member institutions to remove current NCAA bylaw constraints on how student-athlete names and likenesses may be used in commercial and promotional ventures. This increased use, in turn, may lead courts to decide that there is not enough left to the amateurism principle to continue it even for pay for play.

Other consequences are predictable. The largest FBS programs have the biggest donors and are the ones most likely to negotiate major commercial and promotion contracts. ${ }^{188}$ These athletic departments already have major multimedia rights deals for sponsorship, signage, and advertising. Ohio State University, for example, has a ten-year, $\$ 110$ million multimedia rights deal with IMG College while Alabama renegotiated a ten-year, \$76 million deal

187 Declaration of James E. Delany in Support of the NCAA's Class Certification Opposition Brief at 3, In re NCAA Student-Athlete Name and Likeness Licensing Litig., No. 09-cv-1967-CW (N.D. Cal. Mar. 14, 2013).

188 See, e.g., Hemsley, supra note 85. 
with IMG College and Learfield Jet that had minimum annual guaranteed revenues of $\$ 7.9$ million. ${ }^{189}$

Donors interested in helping these athletic programs might be willing to sign on for institutional promotions and commercials simply so revenues from these projects could flow through to studentathletes, with the expectation that the opportunity for these revenues will entice student-athletes to attend their schools. Coaches at these schools no doubt will use the opportunity for name and likeness compensation as a recruiting inducement to prospective studentathletes. Prospective student-athletes already make choices about which university to attend that are too much influenced by factors other than the student benefits of the greater campus and the academic opportunities that are available. The economic motive would be yet another distraction.

Student-athletes are talented athletically, but professional athletes in general are more talented than all of them and much more talented than all but a few of them. The percentage of football and men's basketball student-athletes who play professionally is under two percent. ${ }^{190}$ As described by former men's basketball student-athlete Tom McMillen, "[A] youngster gambling his future on a pro contract is like a worker buying a single Irish Sweepstakes ticket and then quitting his job in anticipation of his winnings." "191 A college team

189 Michael Smith, Alabama Looks To Rework Rights Deal, STREET \& SMITH'S SPORTS Bus. DAILY (Aug. 5, 2013), http://m.sportsbusinessdaily.com/Journal/Issues/2013/08/05 /Colleges/Alabama.aspx.

190 In 2012, 1.7\% of college football players were drafted (255 of 67,887) and 1.2\% of men's basketball players (48 of 17,500). Tony Manfred, Here Are The Odds That Your Kid Becomes A Professional Athlete (Hint: They're Small), BuS. INSIDER (Feb. 10, 2012), http://www.businessinsider.com/odds-college-athletes-become-professionals-2012-2?op $=1$. Baseball players average above ten percent drafted $(806$ of 31,264). Id. But these numbers reflect only the professional draft, and not players who make it to the major leagues. Four of the top ten 2010 draft picks (Gerrit Cole and Trevor Bauer, UCLA; Danny Hultzen, University of Virginia; and Anthony Renden, Rice) were college baseball players. See Albert Chen, Fast Trackers, SPORTS IlluSTRATED, July 8, 2013, at 25, available at http://sportsillustrated.cnn.com/vault/article/magazine/MAG1207956/index .htm. None made it to any higher professional league than Single A Minor League Baseball. Of the top ten 2012 draft picks, five (Mark Appel, Stanford; Kris Bryant, University of San Diego; Jonathan Gray, Oklahoma; Colin Moran, North Carolina; Hunter Dozier, Stephen F. Austin State) were college players. None made it to any higher professional league than Single A Minor League Baseball.

191 ZIMBALIST, supra note 8, at 16. 
may overpower its opponents at the college level, but no college team is likely to beat a professional one. ${ }^{192}$

The collegiate model assures that there is a marketable commodity called intercollegiate athletics that is different from the market for professional sports. It helps attract an audience to college athletics. Absent amateurism, the world of intercollegiate athletics might morph into something much like minor league baseball or arena football. In turn, there is a risk that intercollegiate athletics will lose its viability and attraction to fans. Were that to happen, collegiate athletic revenues would then begin to dry up - even in football and men's basketball - to the ultimate detriment of college athletics and all student-athletes.

\section{$\mathrm{V}$ \\ VALUING AN FBS FoOTBALl STUDENT-ATHLETE AND A DIVISION I MEN'S BASKETBALl STUDENT-ATHLETE}

The issue addressed in the Keller/O'Bannon litigation, and the catalyst for this Article, is whether student-athletes are entitled to compensation when their universities derive revenues from use of their names and likenesses. Student-athlete entitlement to name and likeness compensation, however, presupposes an ability to determine student-athlete name and likeness value. Unfortunately, such an econometric model of the name and likeness value of student-athletes is not feasible.

\section{A. Preliminary Comments}

Texas A\&M estimated that Johnny Manziel was worth only an additional twenty thousand dollars to the school in 2012, the year he won the Heisman Trophy. ${ }^{193}$ How did it get there? By separating out

192 Steve Spurrier, head football coach at the University of South Carolina, opined that the 2012 University of Alabama football team could beat an NFL team. Marc Sessler, Steve Spurrier: Alabama Could Beat "Couple” NFL Teams, NFL.COM (Oct. 31, 2012, 3:01 PM), http://www.nfl.com/news/story/0ap1000000088242/article/steve-spurrier -alabama-could-beat-couple-nfl-teams. The comment was widely derided. See, e.g., Doug Farrarr, Steve Spurrier Thinks That Alabama Could Compete With NFL Teams, And Here's Why He's Wrong, YAHOO! SPORTS (Oct. 31, 2012, 6:22 PM), http://sports .yahoo.com/blogs/nfl-shutdown-corner/steve-spurrier-thinks-alabama-could-compete-nfl -teams-222231388 - nfl.html; ylt=A0LEVw4C hVTnBcAc8NXNyoA; ylu=X3oDMTE zdmFpcnQzBHN1YwNzcgRwb3MDMgRjb2xvÄ2JmMQR2dGlkA1NNRTQwM18x.

193 Curtis Eichelberger, Manziel's Heisman Brought Texas A\&M about \$20,000, School Says, BlOOMBERG News (Nov. 1, 2013, 6:00 AM), http://www.bloomberg.com/news /2013-11-01/manziel-s-heisman-brought-texas-a-m-about-20-000-school-says.html. 
all its fixed revenues - sold out stadiums and related seat licensing fees, sales of luxury suites, long-term TV and radio contracts, corporate sponsorship deals - on which Manziel's football participation had no direct impact. ${ }^{194}$ On the other hand, if no one played football at A\&M, A\&M obviously would have no football revenues. Hence, in a nutshell, the dilemma is identifying the value that individual student-athletes contribute to a team's total revenues, much less identifying the value attributable exclusively to their name and likeness value. ${ }^{1}$

Two points must be emphasized about the econometric model of student-athlete value set forth in this Part. First, and as with all student-athlete value models, our econometric model does not attempt to estimate student-athlete name and likeness value. Instead, we consider overall revenues generated by FBS football and Division I men's basketball programs and then attempt to place a monetary value on the contributions to overall revenues of FBS football and Division I men's basketball student-athletes. That being the case, inevitably our model embodies student-athlete monetary values that are larger than their name and likeness values, were those values capable of specific measurement. Second, our econometric model of student-athlete value is just that. It neither accounts for any offsetting benefits provided to a student-athlete by his university ${ }^{196}$ nor considers a university's contribution to the independent marketing value of a student-athlete while enrolled at the university and thereafter. ${ }^{197}$

${ }^{194}$ Id. The twenty thousand dollars directly attributable from Manziel came from royalties from the sale of football jerseys with his number on them and money paid by donors to sit at his table at a fundraising dinner. Id.

195 In denying class action certification to the damages subgroup in the Keller/O'Bannon litigation, the judge discussed what, in antitrust terms, is known as the "substitution effect." Class Certification Order, supra note 151, at*18-22; see ZF Meritor, LLC v. Eaton Corp., 696 F.3d 254, 292 (3d Cir. 2012). In other words, if a student-athlete or group of student-athletes elects not to play football or men's basketball, others will take their place. Similarly, if some might have stayed in college had there been revenues to them from a group licensing deal, they would have displaced others who would have played had they left. In addition, some universities might move from Division I to Division III because they could not afford to pay royalties or compete for prospective student-athletes.

196 What the offsetting benefits may be are discussed elsewhere in this Article. See supra notes $94-115$ and accompanying text.

197 Separating out the university component of a student-athlete's value will be no easier than identifying a student-athlete's value to a university. Depending on when such valuation is calculated, moreover, it also will be complicated by calculating future value. 


\section{Athletic Department Revenue Accounting}

There also are inherent difficulties in the data used in our econometric model. One difficulty lies in comparing revenue sources among universities. A second difficulty is in considering revenues without consideration of matching expenses.

\section{a. Revenues}

The first difficulty in our data lies in comparing revenue sources among universities due to the different methods used by universities to account for revenues. The main revenue sources for universitiesat least those in the five major FBS Conferences: the Big Ten, Pac 12, ACC, SEC, and Big 12 - are (1) gate revenues, with football claiming the lion's share; (2) annual donations, ${ }^{198}$ including suites and club seating and booster club dues; (3) conference distributions (including distributions to a conference from the NCAA); (4) individual university multi-media rights, such as radio broadcasts; (5) concession and retail sales; (6) licensing; and (7) sponsorships. The five major FBS conferences pool and share equally with their members both revenues from bowl games and revenues from conference media contracts. ${ }^{199}$ Universities in these conferences generally retain revenues from marketing, donations (including suites and courtside seats), corporate sponsorships, licensing, retail sales, and, except for the Big Ten conference, gate revenues. ${ }^{200}$

See Michael R. Morris, Michael Jackson Estate’s Valuation $(\$ 2,105)$ vs. IRS' MJ Valuation (\$434 Mil.): Guest Post, BILlbOARD BIZ (Nov. 11, 2013, 1:55 PM), http://www .billboard.com/biz/articles/news/legal-and-management/5785834/michael-jackson-estates -valuation-2105-vs-irs-mj.

198 Donations can be twice the amount derived from television revenues. Kristi Dosh, Why Women's College Basketball Operates at a Deficit, Bus. C. SPORTS (Oct. 15, 2013), http://businessofcollegesports.com/2013/10/15/why-womens-college-basketball-operates -at-a-deficit/.

199 See, e.g., Patrick Rishe, SEC, Big 12 Report Record-Setting Revenues for 2012-13, FORBES (June 3, 2013, 2:11 PM), http://www.forbes.com/sites/prishe/2013/06/03/sec-big -12-report-record-setting-revenues-for-2012-13/; Jon Wilner, Pac-12 Revenue Soars: School-By-School Breakdown, Scott's Compensation and More, C. HotLINE (May 20, 2013, 3:00 PM), http://blogs.mercurynews.com/collegesports/2013/05/20/pac-12-revenue -soars-school-by-school-breakdown-scotts-compensation-and-more/; David Teel, Teel Time: Swofford Discusses ACC Divisions, Revenue Sharing, Bowls, DAILY PRESS (May 7, 2013, 4:58 AM), http://www.dailypress.com/sports/teel-blog/dp-teel-time-swofford-acc -divisions-revenue, 0,4602904 . story?page $=2$.

200 See Rishe, supra note 199; Wilner, supra note 199; Teel, supra note 199; Scott Dochterman, Indiana Moving 2010 Game to Washington Won't Alter Big Ten Revenue Sharing, GAZETTE (Sept. 29, 2009, 11:21 AM), http://thegazette.com/2009/09/29/indiana -moving-2010-game-to-washington-wont-alter-big-ten-revenue-sharing/; Governance and 
Although the major revenue sources are the same across FBS conferences, there are difficulties in identifying how each school accounts for the particular revenue streams it receives. For example, schools that require donations to purchase certain football tickets may account for the donations in football revenues or, alternatively, as part of general university funds. The data used in our model show donations made specifically to the football and men's basketball programs, but it is unclear whether each school accounts for them in exactly the same way. These discrepancies could represent a minor undercount in some of the data. Unless they are systematically related to the level of revenues of the schools, however, they should not introduce significant bias into the results of our modeling.

\section{b. Matching Expenses}

A second difficulty in our data is that we have no information about university expenses to match our corresponding revenue data. For example, in the Big Ten Conference, member universities share gate revenues in football $(\$ 300,000$ or $35 \%$ of game revenues up to $\$ 1$ million). ${ }^{201}$ A Big Ten university’s revenue accounts may show its total ticket revenues and list as an expense the percentage of ticket revenue that is remitted to the conference office. At the same time, that university's revenue accounts will show a conference distribution that includes its one-twelfth share of pooled ticket revenues. The result: the university's revenue records will show a double count of ticket revenues of up to $\$ 7$ million. These difficulties in our data are important in an accounting framework when looking at levels of revenues across schools but are less critical in our econometric analysis of student-athlete value.

Some measurement error, as long as it does not all lead in one direction - either to a systematic over- or under-count-will not systematically bias our estimates of the marginal value of football and

Commitment to Rules Compliance, PURDUESPORTS.COM, http://www.purduesports.com /school-bio/pur-compliance.html (last visited Mar. 8, 2014). Differences in distribution are attributable to differences in NCAA distributions that are based on number of sports sponsored, number of student-athletes, and, in some conferences, differences in distribution of men's basketball tournament revenues.

201 Dochterman, supra note 200; Governance and Commitment to Rules Compliance, Fiscal Integrity, Self Study Items, Part B, PURduE ON CAMPUS, http://www.purdue sports.com/school-bio/pur-compliance.html (last visited Mar. 24, 2014). Gate revenues also are shared for men's basketball ( $\$ 29,000$ or thirty-five percent of game revenues up to $\$ 67,000)$. 
men's basketball student-athletes. Our econometric analysis estimates the impact of changes in team and market characteristics on changes in team revenues. True levels might be somewhat higher or lower than those reported. As long as changes in these levels respond to the important factors in our models, however, our estimates should be largely unbiased.

\section{Marginal Revenue Product}

As noted above, it is not possible to create an econometric model that exclusively measures the revenues attributable to the name and likeness value of student-athletes. Therefore, existing econometric models - including ours - consider overall revenue streams produced by a university's football and men's basketball program. In economic terms, the issue is how to estimate the marginal revenue product of a football or men's basketball student-athlete. ${ }^{202}$

Even more significant than the difficulties of accounting for revenue streams is the difficulty of appropriately assessing what proportion of a school's revenues are attributable, respectively, to student-athletes, ${ }^{203}$ team performance, coaches, or, as discussed above, the school itself. In our methodology, we report the results of different assumptions concerning these proportions so that readers may see the effect of the split on the final results.

\section{Value}

We described above the caveats and qualifications in conducting a study to estimate the value contributed by football and men's basketball student-athletes to overall revenues in their sport as well as the infeasibility of estimating in particular their name and likeness value. In the succeeding sections, we discuss the existing literature and also provide detailed information regarding the structure and conclusions of our study. For full information on the econometric estimations, see Tables 1 and 2 below. ${ }^{204}$

As detailed below, our model bases student-athlete ability on his ranking at recruitment as either five-star, four-star, or three-star. We

202 The marginal revenue product of a football student-athlete is defined as the extra football revenue a school receives because that player is part of the team.

203 Not to mention the difficulty in attributing revenues to particular student-athletes.

204 Appendix Tables 1 and 2 contain the complete econometric estimations from the fixed-effects, random-effects, and the instrumental variables (IV) models for both football and men's college basketball revenues and winning percentage equations. 
econometrically estimate his influence on team wins. ${ }^{205} \mathrm{We}$ then estimate the influence of team wins and other factors on overall team revenue. Three sources of team revenue are estimated in our models: The first comes from the influence of the players on team wins. The second is the fixed revenue that comes from longer-term contracts and factors like season tickets. The third is the extra revenue that accrues each year as the market for college sports grows over the sample period. We then attribute the revenue to each team based upon its distribution of five-star, four-star, and three-star players, along with a fixed proportion of each of the fixed components of total revenue. With the assumption that a football team contributes fifty percent of the total revenues attributable to all aspects of a football program, our study shows that at the fiftieth percentile of the player estimates, a football player on a team has a marginal revenue product of approximately $\$ 101,000$ per year. ${ }^{206}$ At the fiftieth percentile of the men's basketball distribution, a men's basketball player has a higher marginal revenue product of roughly $\$ 127,000 .^{207}$

\section{B. The Literature on the Value of a Division I Student-Athlete}

The existing literature estimating student-athlete marginal revenue product is thin. Below, we review three studies ${ }^{208}$ : two by Robert Brown that investigate the value of NFL draftees to their universities, ${ }^{209}$ and one by Erin Lane, Juan Nagel, and Janet Netz that estimates the value of men's basketball student-athletes with three

\footnotetext{
205 See infra Table 3 and accompanying explanation.

206 See infra Table 3.

207 For other assumptions and what they show, see infra Table 3.

208 An additional study, produced by Robert Noll and used in the Keller/O'Bannon litigation is not reviewed here because it is narrower in scope and uses an entirely different methodology tailored to a different purpose. See Expert Report on Class Certification of Robert G. Noll, In re NCAA Student-Athlete Name and Likeness Licensing Litig., No. 09cv-1967-CW (N.D. Cal. Mar. 14, 2013). It is primarily a study attempting to establish noncompetitive behavior. At the end, Noll provides an example of how one might determine damages. Noll uses a top-down approach to count total revenues most directly related to names/likenesses (telecasts, sales of highlight clips, and videogames). Then, after determining that a fifty-fifty split is appropriate between the athlete and the school, Noll allocates the athlete portion to current players on an equal basis and also to former players based upon their presence in rebroadcasts and video games.

209 Robert W. Brown, An Estimate of the Rent Generated by a Premium College Football Player, 31 ECON. INQUIRY 671 (1993) [hereinafter Brown I Study]; Robert Brown, Research Note: Estimates of College Football Player Rents, 12 J. SPORTS ECON. 200 (2011) [hereinafter Brown II Study]. Brown is an economist, most recently from California State University, San Marcos, California. Id. at 200.
} 
different approaches (the LNN Study). ${ }^{210}$ The main shortcoming of existing literature is that it fails to separate monies that flow to schools because of their reputation, athletic history, or "love" from general alumni and fans from the value of a particular student-athlete. As in our analysis, the existing literature assesses student-athlete value by creating a proxy for the talent level of particular studentathletes and estimating how much that talent adds to the number of wins in a season. In turn, the extra wins increase the visibility and marketability of a program and should increase some of the variable revenue streams associated with team success.

The current literature estimating marginal revenue product of athletes utilizes some form of instrumental variables methodology to control for the endogeneity of winning and revenues. ${ }^{211}$ Of primary interest here is the impact of a student-athlete on the revenue streams that accrue to the universities. Once we are able to estimate a studentathlete's influence on wins, we can calculate the student-athlete's influence on revenues through the extra wins generated by that particular student-athlete. The studies differ in the data employed in the models and in the exact type of models used.

Robert Brown produced one of the earliest studies to estimate the value of an NCAA athlete. ${ }^{212}$ His data consisted of information for thirty-nine Division I FBS teams with 1988 revenue figures. His methodology assumed a direct relationship between the number of team players drafted into the NFL and team revenues. Brown's sample of thirty-nine schools averaged eight draftees per team, each of whom was counted as a 1988 team player and was drafted in any of the subsequent three years. The primary shortcoming of the Brown Study is the limitation that a single year of data imposed on the estimation strategy. Without having multiple years per school, Brown was unable to separate the influence of players from the general,

210 Erin Lane, Juan Nagel \& Janet S. Netz, Alternative Approaches to Measuring MRP: Are All Men's College Basketball Players Exploited?, J. SPORTS ECON. 1 (2012) [hereinafter LNN Study]. Lane, and Netz are three economists from applEcon in Ann Arbor, Michigan; Nagel is an economist from Universidad de los Andes, Santiago, Chile. Id. at 1 .

211 An instrumental variables technique is an econometric method that attempts to eliminate the endogeneity from a variable in a model. In our analysis, we postulate that extra wins generate extra revenue. But the reverse could also be true: more revenues can contribute to more wins. If the researcher doesn't account for this endogeneity of wins in an equation of revenue generation, the estimate one gets from the data could be biased upward.

212 Brown I Study, supra note 209. 
unchanging support given to the schools themselves. His results were sensitive to different specifications and the inclusion of different variables, and the estimates of the marginal revenue product of an NFL-drafted athlete ranged from roughly $\$ 540,000$ to $\$ 650,000$. In a more recent research project, Brown expanded upon his earlier work using data from the 2004 to 2005 season and a larger sample of eighty-six FBS teams. ${ }^{213}$ Using a methodology similar to his previous study, the newer models generated estimates of the average marginal revenue product of a drafted player at roughly $\$ 1.1$ million.

The LNN Study focused on Division I men's basketball players from 2001 to $2006 .{ }^{214}$ Because of data availability, their sample of schools varied from 170 to 180 schools per year. The LNN Study utilized three different methods for estimating the marginal revenue product of an NBA-drafted college basketball player. Of primary interest here is their implementation of the Scully ${ }^{215}$ method as compared to our methodology employed below. Loosely outlined, Scully's methodology postulates that player quality leads to team success and team success leads to higher revenues. ${ }^{216}$ Therefore, one can back out player marginal revenue product from a marginal player's influence on team success. ${ }^{217}$ The LNN Study also compared the Scully methodology to the general methodology employed in the two Brown Studies, which assumes that there is a direct relationship between the elite players and team revenues. ${ }^{218}$ The LNN Study was able to compare the results obtained from the different methods and data. $^{219}$

The LNN Study was the first to use data from multiple time periods. As a result, it was the first to estimate panel data models. ${ }^{220}$ We believe panel data models are important because they allow the

\footnotetext{
213 Brown II Study, supra note 209.

214 LNN Study, supra note 210.

215 Gerald W. Scully, Pay and Performance in Major League Baseball, 64 AM. ECON. REV. 915, 915-30 (1974)

216 See id.

217 See id.

218 See LNN Study, supra note 210.

219 Id.

220 Panel data models follow the unit of observation-in our case, the university itself-over multiple time periods. Those methods allow the estimation of individual effects- "fixed effects"- that are essentially a dummy variable or constant for each university. In MRP models, the fixed-effects estimate can be thought of as the part of team revenue that is unchanging across time. It is specific to each school.
} 
separate estimation of revenues that accrue from annual variation in team success, along with revenues that accrue from fixed characteristics of the school or program itself. In all of the implementations, the LNN Study rejects ordinary least squares (OLS) regression models ${ }^{221}$ in favor of fixed-effects models. However, in their final analysis, panel-data models are abandoned in favor of the OLS results. Because the OLS estimates of marginal revenue product are roughly three times the size of the fixed-effects estimates, this decision has important implications for their final marginal revenue product estimates. Highlighting just their results from high-revenue schools (schools with over $\$ 10$ million in average revenue for their samples), the LNN Study estimates of the median marginal revenue product are roughly $\$ 950,000$ for the Scully method and about $\$ 1.2$ million for the Brown method for college basketball players drafted by the NBA. ${ }^{222}$

\section{Analysis of Econometric Model}

\section{Data and Methodology}

Our empirical approach is to exploit a panel of data on FBS football and Division I men's basketball revenues so that we are able to separate out the fixed revenue product of a school's popularity or athletic history in the particular sport from the more variable revenue product that comes from elite and "regular" players and the abovetrend wins that they add to a team's success. Part of extra wins can be attributed to having more elite players on the rosters and part to the quality of the rest of the team. While both Brown Studies focused on drafted players, our study uses the distribution of the three-star, fourstar, and five-star recruits on each team. There are shortcomings to using either one as a measure of student-athlete quality as neither proxy is a complete measure of team quality. We feel, however, that in the bigger programs that are the focus of our analysis, the use of the broader range of recruited student-athletes - as opposed to the narrower range of drafted athletes - is a more complete accounting for the quality of the overall squad. ${ }^{223} \mathrm{We}$ are also able to include in

221 OLS models are basic line-fitting models that ignore the panel component, the characteristic of the data that allows the researcher to follow a single school's revenues over time.

222 LNN Study, supra note 210, at 16 tbl.6.

223 The distribution of five-star recruits in a four-year timespan in football is somewhat concentrated in our sample. Only the University of Florida averaged more than single-digit 
our analysis popular student-athletes who were not drafted by the NFL or NBA.

Our data cover the 2005 through 2012 academic years and come from various sources. Revenue and Expense data are from the Equity in Athletics Data Analysis (EADA) tool. ${ }^{224}$ The NFL and NBA draft data were obtained from the Sports Reference website. ${ }^{225}$ Demographic, income, education, and household expenditure data from the areas surrounding the universities are obtained from various years of the Estimates Professional Database maintained by Geolytics. $^{226}$ Team performance data (wins, bowl bids, bowl wins, NCAA tournament appearances and wins, and school attendance figures) were obtained from the NCAA website and individual school websites. ${ }^{227}$ Team recruit lists were obtained from Rivals.com, a part of Yahoo Sports that is concerned with all things related to the identification, development, tracking, ranking, and cataloging of high school football and basketball recruits. ${ }^{228}$ Finally, some team revenue data that filled in gaps in the EADA data, along with football coaching records and rosters, were generously provided by Winthrop Intelligence. $^{229}$

numbers (eleven) over the sample period. The next ten schools averaged between eight and three five-star recruits, and it falls off from there. The rest of the distribution is split between four-star and three-star recruits, with the top fifteen schools being more heavily four-star, and the rest being more heavily three-star. In men's basketball, the story is similar. The top seventeen schools averaged more than one five-star recruit in a three-year time-span, led by Kentucky, of course, with an average of six. Outside of those schools, another twenty averaged one five-star recruit and then the distribution of recruits is quite variable between four- and three-star recruits. For information regarding our various sources, see infra notes 229-33 and accompanying text.

224 See The Equity in Athletics Data Analysis Cutting Tool, U.S. DEP'T EDUC., http://ope.ed.gov/athletics/Index.aspx (last visited Mar. 8, 2014).

225 See SPORTS REFERENCE, http://www.sports-reference.com/ (last visited Mar. 8, 2014).

226 See GeOLYTICS, http://www.geolytics.com/ (last visited Mar. 8, 2014). Geolytics is a company that provides demographic data, census demographics, market research data, and geocoding for social researchers and business marketing. Company Information, GEOLYTICS, http://www.geolytics.com/Company.asp (last visited Mar. 8, 2014).

227 See, e.g., NCAA.ORG, http://www.ncaa.org/d1 (last visited Mar. 8, 2014).

228 See RIVALS.COM, http://www.rivals.com (last visited Mar. 12, 2014).

229 See WINTHROP, http://winthropintelligence.com/ (last visited Mar. 8, 2014). Winthrop Intelligence provides information to college and university athletic directors relating to athletic program expenses and revenues. Id. 


\section{Descriptive Information}

There is a clear hierarchy in college football when it comes to team revenues. On average, the top ten teams have earned over $\$ 60$ million annually over the past eight years. ${ }^{230}$ In addition, there are forty-five teams that averaged between $\$ 20$ million and $\$ 60$ million annually. ${ }^{231}$ There is a similar pattern in Division I men's basketball, where the top twelve teams have average revenues greater than $\$ 15$ million per year and another seventy-one teams average between $\$ 4$ million and $\$ 15$ million annually. ${ }^{232}$ The range for men's basketball is not as great as in football, but there are many more teams in the middle of the distribution. ${ }^{233}$ Below, Table 1 compares the distribution of the average team revenues in 2013 dollars over the sample period between the top FBS football and Division I men's basketball programs.

230 See infra Table 1 for a more complete list of teams and their average annual revenues.

231 Id.

232 Id.

233 See id. 

the Treatment of Student-Athletes

Table 1: Average Annual School Revenues by Sport in 2013 Dollars: 20052012

\begin{tabular}{|c|c|c|c|}
\hline Football & $\underline{\text { Revenue }}$ & $\underline{\text { Basketball }}$ & $\underline{\text { Revenue }}$ \\
\hline Texas & $92,469,431$ & Louisville & $33,214,631$ \\
\hline Georgia & $74,378,414$ & North Carolina & $21,911,545$ \\
\hline Alabama & $72,120,880$ & Duke & $21,014,411$ \\
\hline Florida & $71,953,212$ & Arizona & $20,013,682$ \\
\hline Auburn & $71,110,206$ & Syracuse & $19,450,540$ \\
\hline University of Notre Dame & $70,006,280$ & Kentucky & $17,929,095$ \\
\hline Michigan & $69,777,028$ & Michigan St. & $17,262,083$ \\
\hline Ohio State University & $68,346,308$ & Indiana & $17,015,428$ \\
\hline LSU & $64,774,924$ & Ohio State University & $17,001,593$ \\
\hline Penn St. & $64,102,298$ & Wisconsin & $16,873,197$ \\
\hline Oklahoma & $52,974,678$ & Texas & $16,791,560$ \\
\hline University of South Carolina & $52,419,412$ & Arkansas & $16,242,137$ \\
\hline Arkansas & $52,348,254$ & Kansas & $15,690,216$ \\
\hline Nebraska & $49,649,826$ & Illinois & $15,431,100$ \\
\hline University of Tennessee & $48,157,692$ & Marquette & $14,889,105$ \\
\hline Michigan St. & $47,762,892$ & Minnesota & $14,350,661$ \\
\hline Iowa & $47,042,149$ & North Carolina St. & $12,723,109$ \\
\hline Texas A\&M & $45,023,436$ & Oklahoma St. & $12,530,519$ \\
\hline Wisconsin & $44,160,858$ & University of Tennessee & $12,422,395$ \\
\hline Washington & $42,886,692$ & Maryland & $12,149,180$ \\
\hline Clemson & $36,113,786$ & Pittsburgh & $11,686,151$ \\
\hline Virginia Tech & $35,779,698$ & UCLA & $11,077,281$ \\
\hline USC & $34,331,780$ & Washington & $10,695,792$ \\
\hline Oregon & $33,714,636$ & Wake Forest & $10,613,754$ \\
\hline Arizona St. & $31,777,727$ & Georgetown & $10,581,386$ \\
\hline Oklahoma St. & $31,282,238$ & Xavier & $10,562,413$ \\
\hline Kentucky & $30,593,379$ & Florida & $10,421,609$ \\
\hline & & Dayton & $10,284,793$ \\
\hline & & Alabama & $10,201,113$ \\
\hline & & Iowa & $10,098,500$ \\
\hline & & Northwestern & $10,084,022$ \\
\hline 28 Schools: $\$ 20-30$ million & & \multicolumn{2}{|l|}{52 Schools: $\$ 4-10$ million } \\
\hline 20 Schools: $\$ 10-20$ million & & \multicolumn{2}{|l|}{174 Schools: $\$ 1-4$ million } \\
\hline
\end{tabular}




\section{Specification Issues and Models}

There are three main issues involved in estimating a model of team revenues over time. The first is how the possible endogeneity of important variables is handled. The second is the question of whether panel data techniques or simple OLS models are estimated. Finally, there is the question of whether time should be included as a factor in the models. How team revenues are modeled determines many of the differences in estimates of marginal revenue product found in the literature to date.

The first issue involved in estimating a model of team revenues over time is in handling the possible endogeneity of important variables. The estimation of marginal revenue product for studentathletes involves some form of a revenue equation where team revenues are a function of team quality along with various other controls measuring school characteristics (school size, stadium/arena capacity, conference) and market characteristics (population, income, etc. in the area of the school). In all cases, there is the possibility that wins and team quality are simultaneously determined. If so, the OLS estimates for the influence of quality players on team revenues will suffer from an upward bias, causing one to overestimate their effect on revenues. The solution to this problem is to use instrumental variables techniques in an attempt to get an unbiased estimate for the impact of team quality on revenues.

Methods used in the two Brown Studies used the number of athletes who were drafted into the professional leagues as an explanatory variable for team wins. Scully and the LNN Study used team performance statistics. In our football and men's basketball models, we measure the influence of player talent on team wins by individual player recruiting ratings from Rivals.com. Each team is made up of a certain number of five-star, four-star, and three-star recruits. These measures, along with other team-quality controlssuch as head coach and staff, two-year historical coaching success, staff size, and operations costs - act as instruments in a first-stage equation that predicts team quality as measured by winning percentage. The predicted value from the first-stage winning percentage equation is then used in the revenue equation to produce an unbiased estimate of the effect of wins on revenues. We employed the Hausman test ${ }^{234}$ for endogeneity and found that endogeneity is

234 J.A. Hausman, Specification Tests in Econometrics, 46 ECONOMETRICA 1251, 1251-71 (1978). 
not an issue in our data, so our final models are not the instrumental variables models discussed above.

The second issue involved in estimating a model of team revenues over time is the question of whether panel data techniques or simple OLS models are estimated. More specifically, the question is whether to exploit the time-dimension of the data and to use panel data techniques to generate fixed-effects estimates for each school. Essentially, any systematic level of revenue that accrues to the school but does not vary over time and does not vary with any of the other covariates (attendance, team quality, income changes in the area, etc.) is measured by the fixed effect. Because the data in Brown's two studies were cross-sectional, his research could not produce a fixedeffects estimate. ${ }^{235}$ By contrast, the research reported in the LNN study contains both panel and OLS estimations. We performed Ftests - tests of whether the fixed-effects estimates are statistically different from zero - on the fixed-effects estimations illustrated below and found that all rejected the hypothesis that the fixed effects are zero. This means that there is in fact a part of the revenue that schools accrue that is unchanging and should be attributed to athletes. We discuss how to attribute this component of the school revenue in more detail below.

The third issue involved in estimating a model of team revenues over time is the question of whether time should be included as a factor in the models. More specifically, the issue is whether to include a time trend in the data to account for the overall growth in FBS football and Division I men's basketball real total revenues over time. The various models in the LNN Study include a time component. The Brown Studies do not because Brown's data lacked a time dimension. Our football and men's basketball models also include a time trend. It can be interpreted as an average amount of extra revenue that accrues to each school simply because there is more money in the sport each year. We will also discuss how to attribute this portion to the studentathletes in more detail below.

Equation 1 outlines the general form of the models being estimated for FBS football and Division I men's basketball revenues. Our sample is restricted to football programs with average annual revenues totaling more than $\$ 10$ million over the sample period and to basketball programs with average annual revenues over $\$ 4$ million.

235 See supra note 209 and accompanying text. 
We excluded football and men's basketball programs that generated less revenue because we found very little to no correlation between revenues and player characteristics in those programs. Equation 2 is the specification for the team success equation and serves as the first stage for the two-stage least squares estimations that are tested.

(1)

$$
\begin{aligned}
& \text { Revenue }_{i t}=A+\beta_{1} \text { Win }_{\text {it }}+\beta_{2}{\text { MedAge } 100 m_{i t}}_{i}+\beta_{3} \ln H \text { HInc } 100 m_{i t} \\
& +\beta_{4} \ln \text { HHEntertainExp } 100 m_{i t}+\beta_{5} \% \text { MenWithBA } \\
& +\beta_{6} \# \text { Students ' } 000_{i t}+\beta_{7} \% \text { OutOfState }{ }_{i t}+\beta_{8} \text { SeasonAttendance' } 000_{i t} \\
& +\sum_{t=2006}^{2012} \beta_{t} \text { Year }_{t}+\sum_{k=1}^{5} \beta_{k} \text { Conf }_{k}+\sum_{i=1}^{s} \mu_{i}+\varepsilon_{i t}
\end{aligned}
$$

$$
\begin{aligned}
\text { Win }_{i t}= & A+\beta_{1} \text { Sum5Star }_{i t}+\beta_{2} \text { Sum }_{\text {Star }} \text { Stt }_{i t}+\beta_{3} \text { Sum } 3 \text { Star }_{i t} \\
& +\beta_{4} \text { HeadWin }_{i t}+\beta_{5} \text { HeadBowls }_{i t}+\beta_{6} \text { StaffWin }_{i t}+\beta_{7} \text { StaffBowls }_{i t} \\
& +\beta_{8} \text { StaffSize }_{i t}+\beta_{9} \ln \text { OpExp }_{i t}+\beta_{10} \text { SchedStrength }_{i t}+\sum_{i=1}^{s} u_{i}+\varepsilon_{i t}
\end{aligned}
$$

The variables in Equations 1 and 2 are defined as follows: Revenues are total revenues for football and men's basketball separately as reported to the Department of Education in each academic year. Winning percentage is total wins divided by total games and multiplied by 100 . The natural $\log (\log$ base e) of median household income and median household expenditures on entertainment and the percentage of men with a Bachelor of Arts degree are for a 100-mile radius around the campus. These are used as proxies for the consumer market characteristics of wealth and education levels in the vicinity of the university. ${ }^{236}$ Other characteristics for each school are the size of the student body, the percentage of out-of-state students, and the total attendance figures for football and men's basketball in each year. These factors also control for the student population and fan interest in the sport. The factors in the winning percentage equation are a four-year history of the number of five-star, four-star, and three-star recruits in football, and a three-year history of the number of five-star, four-star, and three-star recruits in men's basketball. ${ }^{237}$ The football equation also

\footnotetext{
236 Alternative specifications with a 50-mile radius and 150-mile radius were tested and produced no qualitatively different results.

237 We use a shorter recruit history for men's basketball because the rules around being eligible for the professional draft are different than in football. Basketball student-athletes
} 
contains coaching success measures for the head coach and the rest of the staff. First, we construct a winning percentage for each coach in each year that he coached. Then we look two years prior to the current year and construct the average winning percentage and the number of bowl appearances in the previous two years for the composition of coaches in the current year at the particular school. This creates measures of coaching quality that are related to the current coaching staff but are independent of the current season. We do not have equivalent detailed men's basketball coaching data, so the men's basketball equation omits those factors. Finally, to help explain a football or men's basketball team's winning percentage, there are measures of the total staff size, natural logs of operating expenses, and schedule strength ratings.

\section{Results}

Table 2 provides selected estimates from the various possibilities for modeling Equations 1 and 2. When comparable, we compare similar estimates from the existing literature. As discussed above, there are three main choices in modeling the system of equations. There are two panel data choices: random effects and fixed effects. The choice between those two methods involves the statistical test of whether or not the fixed effects equal zero. The third choice is whether instrumental variables techniques are required. This would be the case if the winning percentage variable in the revenue equation were found to be endogenous as discussed above. The model estimates of primary interest are at the top of Table 2, the various test statistics are provided in the middle, and basic model diagnostics and information are at the bottom.

need only stay in college for one year. See infra note 299 and accompanying text. Football student-athletes must be out of high school for at least three years. Since we do not have an exact accounting of which players left early and which did not, we allow four years of recruiting classes for the football models and three for the basketball models to proxy for the team composition. 
Table 2: Selected Results from Different Specifications of FB and BB Equations

\begin{tabular}{|c|c|c|c|c|c|c|}
\hline & $F B-R E$ & $F B-F E$ & $F B-I V$ & $B B-R E$ & $B B-F E$ & $B B-I V$ \\
\hline \multicolumn{7}{|l|}{ Effect on Win \% } \\
\hline 5-Star Recruits & 1.30 & 1.77 & 1.68 & 1.96 & 1.20 & $0.61^{t}$ \\
\hline 4-Star Recruits & 0.24 & - & - & - & - & - \\
\hline 3-Star Recruits & 0.16 & - & - & - & - & - \\
\hline \multicolumn{7}{|l|}{ Effect on Revenues } \\
\hline $\begin{array}{l}1 \% \uparrow \text { Winning } \% \\
\text { Average } \uparrow \text { Per }\end{array}$ & $\$ 43,206$ & $\$ 57,563$ & $\$ 141,793$ & $\$ 3,235^{t}$ & $\$ 10,352$ & $\$ 34,562$ \\
\hline Year & $\$ 1,286,321$ & $\$ 1,296,035$ & $\$ 1,293,416$ & $\$ 343,400$ & $\$ 348,106$ & $\$ 348,968$ \\
\hline 5-Star Impact & & $\$ 101,887$ & & & $\$ 12,422$ & \\
\hline \multicolumn{7}{|l|}{ Prob $>\chi^{2}$ (Hausman) } \\
\hline IV vs. FE & & .700 & & & 1.00 & \\
\hline FE vs. RE & & .000 & & & .000 & \\
\hline \multicolumn{7}{|l|}{ Overall $\mathrm{R}^{2}$} \\
\hline Winning $\%$ & $29 \%$ & $12 \%$ & $9 \%$ & $13 \%$ & $11 \%$ & $17 \%$ \\
\hline Revenue & $63 \%$ & $22 \%$ & $13 \%$ & $47 \%$ & $34 \%$ & $21 \%$ \\
\hline \multicolumn{7}{|l|}{ F-Test $u_{i}=0$ p-value } \\
\hline Winning $\%$ & & .000 & .000 & & .000 & .000 \\
\hline Revenue & & .000 & .000 & & .000 & .000 \\
\hline Revenue Eq. Obs. & 493 & 493 & 493 & 563 & 563 & 563 \\
\hline \# of Schools & 64 & 64 & 64 & 75 & 75 & 75 \\
\hline Max. Time Period & '05-’12 & '05-’12 & '05-’12 & '05-’12 & '05-'12 & '05-’12 \\
\hline
\end{tabular}

Notes: $\mathrm{RE}=$ Random Effects, $\mathrm{FE}=$ Fixed Effects, IV=2SLS. ${ }^{\mathrm{t}} \mathrm{p}$-value $<.25$.

The first results to highlight are the F-tests for the significance of the fixed effects. In both instrumental variables and OLS formulations, the fixed effects that are equal to zero are strongly rejected. Those results are similar to the LNN Study findings. ${ }^{238}$ In other words, no model that tested for fixed effects rejected them as a contributing factor in revenue production. The Hausman test also points in the same direction. ${ }^{239} \mathrm{~A}$ comparison of the instrumental

238 See LNN Study, supra note 210.

239 See Hausman, supra note 234. 
variable with the fixed-effect estimates shows no significant difference between the two, which suggests any presence of endogeneity is minimal in our models. The LNN Study also found endogeneity in some of their models and did not find any in others. ${ }^{240}$ Finally, the second row of $\chi^{2}$ statistics suggests that the fixed-effects models are preferred to the random-effects models, again showing the importance of accounting for the fixed school-level revenues that do not vary with the other covariates in the models.

The remaining discussion focuses on the middle column within each group of football and men's basketball models, the fixed-effects models. Each five-star football recruit adds on average $1.77 \%$ to a team's winning percentage. ${ }^{241}$ Each five-star men's basketball recruit adds $1.20 \%{ }^{242}$ Multiplying these estimates by the impact of a one percentage-point increase in wins on revenues yields estimates of $\$ 101,887$ for a five-star football recruit and $\$ 12,422$ for a five-star men's basketball recruit. Our estimate of the effect of a onepercentage-point increase in men's basketball winning percentage$\$ 10,352$ - is a similar order of magnitude to the $\$ 29,349$ estimate reported in the LNN Study for large schools. ${ }^{243}$ Some of the difference could be attributed to our large-school sample containing schools with average revenues down to $\$ 4$ million as compared to the LNN Study's cut-off at $\$ 10$ million. ${ }^{244}$ Our results for football fivestar recruits - $\$ 101,887$ - are orders of magnitude lower than Brown's various estimates of $\$ 500,000$ to $\$ 1$ million. $^{245}$ There are many likely reasons for this difference.

First, because Brown had no panel of data, some information contained in our fixed-effects estimates are likely attributed to his estimates on the value of draft picks. Second, Brown models the value of draft picks while we model recruits. Although many draft picks are initially five-star recruits, it is not a perfect one-to-one matching. Finally, without the time dimension in his data, Brown's estimates lack any accounting for the growth in the overall size of revenue in football and men's basketball. Just as the same caliber player will have a different marginal revenue product if he plays for Louisiana

\footnotetext{
240 See LNN Study, supra note 210.

241 See supra Table 2.

242 Id.

243 Id.

244 Id.

245 Id.
} 
State University instead of University of Louisiana-Monroe, some part of our estimates for the time effect should also be attributed to the student-athlete himself. Stated another way, some part of the marginal revenue product is dependent upon the existing market conditions in which a student-athlete competes.

The results from the fixed-effect estimates of football and men's basketball were used in the final calculations of average studentathlete marginal revenue product. Our estimates have three components: The first is the impact of the players on wins. The number of five-star recruits on each team is multiplied by the effect of the student-athletes on wins, and then the impact of the extra wins on revenue is calculated. The second component is the fixed effect. Each team has its own estimate of the average level of revenues that accrues each year because of the fixed parts of the demand for football and men's basketball. These factors include, for example, longer-term luxury box revenues, television revenues, conference bowl or tournament disbursements, and any other general, unchanging, revenue-generating support for the program. Some part of these revenues should be attributed to the student-athletes and some to the schools and coaches. Without a direct way to attribute them, we present different sets of results to see how sensitive our findings are to the different assumptions. The third component is the time effect. On average, over-time real revenues to each team have increased because of the growth in sport popularity. The time effects measure this increase and it is added to the total value of each team and treated in the same way as the fixed effects.

Below, Table 3 contains the results of these calculations under different assumptions for how the fixed component of revenue is attributed. We evaluate a twenty-five-, fifty-, and seventy-five-percent value attributed to the student-athletes. The results are presented for the teams at the ninetieth, seventy-fifth, fiftieth, twenty-fifth, and tenth percentiles of student-athlete marginal revenue product. 
Table 3: MRP Estimates for NCAA Football and Men's Basketball Players: Annual \$ 2013

\begin{tabular}{lcccccc}
\hline \hline & & Football & & & Basketball & \\
\% Fixed \\
$\begin{array}{l}\text { Value to } \\
\text { SAs: }\end{array}$ & $\mathbf{2 5 \%}$ & $\mathbf{5 0 \%}$ & $\mathbf{7 5 \%}$ & $\mathbf{2 5 \%}$ & $\mathbf{5 0 \%}$ & $\mathbf{7 5 \%}$ \\
\hline $\begin{array}{l}90^{\text {th }} \\
\text { Percentile }\end{array}$ & 110,578 & 220,278 & 329,977 & 186,155 & 370,484 & 554,812 \\
$\begin{array}{l}75^{\text {th }} \\
\text { Percentile }\end{array}$ & 74,731 & 149,292 & 223,853 & 108,298 & 215,215 & 322,132 \\
$\begin{array}{l}50^{\text {th }} \\
\text { Percentile }\end{array}$ & 51,498 & 101,439 & 152,113 & 64,037 & 127,660 & 191,284 \\
$\begin{array}{l}25^{\text {th }} \\
\text { Percentile }\end{array}$ & 28,175 & 56,112 & 84,049 & 31,500 & 63,002 & 94,503 \\
$\begin{array}{l}10^{\text {th }} \\
\text { Percentile }\end{array}$ & 2,674 & 5,349 & 8,023 & 5,319 & 10,378 & 15,957
\end{tabular}

Those results suggest a wide range of estimates depending upon how much one attributes the fixed revenues to the team itself. In general, the estimates are lower than those presented in the literature, and, as discussed above, this is likely due to the use of the fixedeffects estimation results. Just looking at a fifty-fifty split between value attributed to the players and value to all other aspects of the program, a football player on the median team in the football distribution has a value of approximately $\$ 101,000$ per year. A men's basketball player at the same place in the distribution has a higher value: roughly $\$ 127,000$. Even though total men's basketball team revenues are orders of magnitude lower than football revenues, the smaller squad sizes mean that the lower revenues are spread among far fewer players and each player has a higher marginal value. The implications of considering some kind of compensation scheme are explored in the sections that follow.

VI

\section{ACCOMMODATING STUDENT-ATHLETE NAME AND LIKENESS COMPENSATION WITHIN THE COLLEGIATE MODEL}

Were student-athletes to receive a share of revenues from university, conference, and NCAA licensing ventures in which their names or likenesses are used, several consequences might ensue. This section discusses some of them. 


\section{A. Title IX}

Title IX requires that institutions that receive federal funds offer equal athletic opportunities to women and men. ${ }^{246}$ A nonexclusive list of ten criteria is used to determine if there is equal treatment between men and women student-athletes and their teams. ${ }^{247}$ No criterion addresses institutional promotional or commercial activities, and since student-athletes currently can accept no pay, no criterion addresses equality in payments for these activities.

With regard to playing fields and equipment, Title IX requires equal treatment even if, for example, donor funds offered for facilities for one gender have to be declined because a school cannot find funds to upgrade facilities for the other gender. ${ }^{248}$ But equal treatment with regard to promotional and commercial ventures is a dance that requires two willing partners. To be sure, in at least one sense, an athletic department is in complete control over which teams or athletes are used in its marketing or commercial ventures. That being so, it could condition use of football and men's basketball studentathlete names and likenesses on a marketing or broadcast partner's willingness to use an equal number of women student-athletes and,

24620 U.S.C. $\S \S 1681-1688$ (2012).

247 The ten factors were developed in 1975 by the Department of Health, Education, and Welfare. 34 C.F.R. $\S 106.41$ (c) (2013); 45 C.F.R. $\S \S 86.1-86.71$ (2013). They are equality in (1) the selection of sports and levels of competition in university athletic programs so as effectively to accommodate the interests and abilities of members of both sexes; (2) the provision of equipment and supplies; (3) scheduling of games and practice times; (4) travel and per diem allowance; (5) opportunity for coaching and academic tutoring; (6) assignment and compensation of coaches and tutors; (7) provision of locker rooms, practice and competitive facilities; (8) provision of medial and training facilities and services; (9) provision of housing and dining facilities and services; and (10) publicity. 34 C.F.R. $\S 106.41(\mathrm{c})$. The first factor, "effectively accommodat[ing] the interests and abilities of members of both sexes," id., has, to date, captured virtually all the public attention and has been the subject of virtually all court challenges. See, e.g., Cohen v. Brown Univ., 991 F.2d 888, 897 (1st Cir. 1993). Courts have struggled with how to determine whether women and men have equal athletic participation opportunities (in other words, that their interests and abilities are effectively accommodated). See id. There are at least two reasons for the difficulty: first, because past patterns of societal discrimination deflated women's interest in athletics and their opportunity to participate, courts have been unwilling to discern women's athletic interest by resorting to historical participation numbers; second, through its athletic department, a university controls the male and female composition of its student-athlete population by decisions as to which sports to sponsor and whom to recruit. Id.

248 Daniels v. Sch. Bd. of Brevard Cnty., 985 F. Supp. 1458, 1462 (M.D. Fla.1997) (holding unequal treatment under title IX where a high school funded boy's baseball and girl's softball equally but used private booster contributions for an electronic scoreboard and field lights for baseball). See generally Cynthia Lee A. Pemberton, More of the Same—Enough Already!, 22 MARQ. SPORTS L. REV. 597, 601 (2012). 
indeed, male student-athletes in other sports. The price would be lost revenues if a marketing or broadcast partner declined the dance. ${ }^{249}$ Nonetheless, market factors are not irrelevant to the calculus even with regard to Title IX. For example, although athletic departments provide sports information for women's teams and attempt to get media coverage for them, universities cannot control whether or how the media cover women's sports. Similarly, the Equal Pay Act recognizes that market factors may influence coach salaries favoring male coaches. ${ }^{250}$

The one incontrovertible thing we can say with regard to the impact of Title IX if student-athletes were to be paid for marketing and promotional ventures in which their names and likenesses are used is that it is not possible to predict the impact of Title IX with any confidence. $^{251}$

\section{B. Dissension}

There is no telling what name and likeness compensation to student-athletes might do to the campus environment, in large part because there currently is no telling the amount of money to be distributed, how, or to whom. We believe that the impact on the campuses or on intra-department student-athlete relationships will be at the margin only, particularly if only a small number of studentathletes reap large sums from the use of their names and likenesses ${ }^{252}$ or if funds are held until after a student-athlete departs from a university. $^{253}$

Some potential impacts are that payments to student-athletes for commercial use of their names and likenesses will enlarge the gulf between the treatment of student-athletes, particularly football and men's basketball student-athletes, and students on the greater campus; undermine efforts to provide equitable treatment to all studentathletes by athletic departments; spur an enhanced sense of

249 A worthwhile subject for discussion would be whether this result might advance the collegiate model more than the use for all student-athletes of revenues attained by marketing and other commercial ventures.

250 Stanley v. Univ. of S. Cal., 13 F.3d 1313, 1322-23 (9th Cir. 1994); Jacobs v. Coll. of William and Mary, 517 F. Supp. 791, 797 (E.D. Va. 1980), aff'd, 661 F.2d 922 (4th Cir. 1981).

251 Stanley, 13 F.3d at 1322-23; Jacobs, 517 F. Supp. at 797.

252 See discussion supra Part VI.

253 Whether by graduation, exhaustion of eligibility, or for other reasons. 
entitlement in football and men's basketball student-athletes; and strain student-athlete interactions. These consequences may occur, but we are unpersuaded that they will make much difference.

In the first place, preferential treatment of football and men's basketball student-athletes already exists. Football and men's basketball are two of only five NCAA head count sports. ${ }^{254}$ Each scholarship athlete in a head count sport receives tuition, room and board, and books (a full-ride scholarship). ${ }^{255}$ All other NCAA sports are equivalency sports. These teams have a maximum amount of scholarship money to distribute among team members but no minimum limit on the amount of aid; a full-ride scholarship is rare. ${ }^{256}$

In addition, public attention for football and men's basketball student-athletes already sets them apart from all other students, including other student-athletes. Eighteen of the twenty largest football stadiums in the United States host college, not professional, games. $^{257}$ Through 2012, the University of Nebraska has had 325 consecutive home football game sell-outs. ${ }^{258}$ Football game days are such big events that security and traffic control costs can run more than $\$ 200,000$. $^{259}$

Football and men's basketball student-athletes also are featured in more local media stories than are student-athletes in other sports, and

254 NCAA MANUAL, supra note $1, \S 15.5 .2$.

255 In head count sports a coach has a specified number of student-athletes to whom he can award scholarships, and every scholarship counts as a full ride no matter whether a full amount is awarded. Id. $\S$ 15.5.2. FBS universities almost always fully fund each scholarship.

256 Id. § 15.5.3. Baseball is one of two outlier programs. Although an equivalency sport, its squad size is capped at twenty-seven and each scholarship student-athlete must receive at least twenty-five percent of a full scholarship. Id. $\S$ 15.5.4. Ice hockey is the other outlier. It is limited to thirty student-athletes who may receive any portion of an athletic scholarship. Id. § 15.5.7.

${ }^{257}$ List of American Football Stadiums by Capacity, WIKIPEDIA, http://en .wikipedia.org/wiki/List_of_American_football_stadiums_by_capacity (last visited Mar. 8, 2014). The "Big House" at the University of Michigan heads the list with stadium capacity of more than 108,000. Sean, Michigan Stadium Capacity to Max Out at 110,000+, Later Drop to 108,000+, Mich. SPORTS CTR. (Aug. 27, 2009, 5:30 AM), http://michigansportscenter.com/2009/08/michigan-stadium-capacity-to-max-out-at -110000-later-drop-to-108000.html.

258 Memorial Stadium-Home of the Huskers, NeB. ATHLETICS, http://www.huskers .com/ViewArticle.dbml?ATCLID=734 (last visted Mar. 8, 2014).

259 Football game day traffic control and security costs can mount. At Clemson and South Carolina, for example, the combined total is nearly $\$ 500,000$. Brennan Somers, Cost of Security at College and High School Sporting Events, WMBF NEWS (July 31, 2013, 3:28 PM), http://www.wmbfnews.com/story/22983292/the-cost-of-security-at-college-and -high-school-sporting-events. 
they get the bulk of national media attention. Countless hours of talk radio in a city with a major FBS school ${ }^{260}$ and a top (or aspiring-tobe-top) football program are devoted to the football team. ${ }^{261}$ Countless hours of talk radio in a city with a major FBS school and a top (or aspiring-to-be-top) men's basketball program are devoted to the basketball team. Prominent players are recognized on campus and by sports fans around the country. March Madness is a national story with office bracket pools everywhere.

If payment for student-athlete names and likenesses would cause additional strain on a campus or in athletics, therefore, it likely will not be among all students or all student-athletes but, instead, within the football and men's basketball teams. There are two models for providing name and likeness compensation. ${ }^{262}$ Student-athletes might be paid for use of their names and likenesses commensurate with their individual value. ${ }^{263}$ For example, the quarterback would be paid more than the walk-on in men's basketball, and elite student-athletes at each position would be paid more than their counterparts at the position. This could lead those with higher values to flaunt their statuses. Alternatively, all football and men's basketball studentathletes might be paid exactly the same amount. ${ }^{264}$ This could lead to resentment from those who believe their value is higher and should be recognized and compensated as such.

In either case, resentments may fester. Although unlikely to lead to shirking on the field, resentments might cause morale issues detrimental to team play. ${ }^{265}$ Resentments could also explode in offfield incidents.

260 Today, this would also include the new Big East Conference with no football or prominent basketball programs. See BIG EAST, http://www.bigeast.com (last visted Mar. 8, 2014).

261 See, e.g., College Hoops Digest Forum: College Basketball Talk Radio, BLOG TALK RADIO, http://www.blogtalkradio.com/collegehoopsdigest/2014/01/04/college-hoops -digest-forum-college-basketball-talk-radio (last visited Mar. 11, 2014).

262 See supra Part IV.

263 Id.

264 This is the model advocated for by the Plaintiff's economist in the Keller/O'Bannon litigation. See Jon Solomon, Ed O'Bannon v. NCAA: The Arguments for and Against a Class-Action Suit, AL.COM (June 15, 2013, 9:00 AM), http://www.al.com/sports /index.ssf $/ 2013 / 06 /$ ed_obannon_v_ncaa_the_argument.html.

265 See, e.g., Lewis C. SOLMON \& MichAEL PODGURSKy, Milken FAM. Found., The Pros AND CONS OF PERformanCe-BASED COMPENSATION 1, 4 (2000), available at http://web.missouri.edu/ podgurskym/articles/files/Pros_cons.pdf; Gaynor McCown \& Wade Nelson, Point/Counterpoint: Teacher Merit Pay: Prudent or Pointless?, SCHOLASTIC ADM'R (June 2004), http://www.scholastic.com/browse/article.jsp?id=234. 
VII

FEDERAL AND STATE INCOME TAX CONSEQUENCES OF MAKING NAME AND LIKENESS PAYMENTS TO STUDENT-ATHLETES

For the reasons discussed above, we conclude that, to the extent universities could quantify name and likeness revenue attributable to specific student-athletes, attempting to share such revenue with the student-athletes would be unwise. Nonetheless, our analysis would be incomplete without examining tax and related problems raised by proposals to share name and likeness revenue. In this discussion, we assume that any such revenue sharing would not be part of a paradigm shift, such as paying student-athletes to play or compensating them with money in hand ${ }^{266}$ for the value of their names and likenesses while they are still students. Instead, our analysis considers the means by which universities ${ }^{267}$ could accumulate and hold such payments until a student-athlete graduates. ${ }^{268}$ In the following sections, we discuss two alternatives for accomplishing this goal and the problems associated with each: first, we discuss university-established holding accounts; second, private express trusts.

266 We make this assumption because a decision to allow universities to pay studentathletes would, at a minimum, cause the universities to lose their current protection from the unrelated business income tax. See supra note 15 and accompanying text. It is also possible that the universities could lose their federal income tax exemption under section 501(c)(3) of the Internal Revenue Code. See 26 U.S.C. § 501(c)(3) (2012).

267 We recognize that it might be possible for companies or the NCAA to create and maintain name and likeness holding accounts. Apart from the practical problems associated with separating such payments from the university context, those alternatives would raise essentially the same income tax issues and associated trust issues discussed in this section of the Article.

268 For ease of discussion, we discuss holding and distributing revenues to studentathletes and key the distribution of revenues to when they "graduate." Revenues could also be distributed when a student-athlete exhausts competition eligibility even if that studentathlete has not graduated. Similarly, revenues could be distributed when a student-athlete irrevocably will no longer compete, even if the student-athlete has eligibility remaining. Such a result could occur, for example, as a consequence of career-ending injury, exclusion from competition because of the commission of violations, or expulsion or suspension for poor academic performance. Accepting a disbursement of revenues would irrevocably end the student-athlete's participation in intercollegiate competition. Thus, graduation is not the only trigger for distribution, but is merely a convenient shorthand reference for purposes of this Article. 


\section{A. University-Established Holding Accounts}

A university could establish accounts ${ }^{269}$ into which it would pay name and likeness revenue allocable to a student-athlete. In the simplest structure, the university would hold the funds until the student-athlete graduated and thereafter would pay the balance in the account to the student-athlete. Because such a structure would not protect a student-athlete against inflation during the period prior to graduation, the university might agree to pay interest at a variable rate based on interest paid by local banks or thrift institutions. The interest would not perfectly compensate for inflation, but would provide some protection to a student-athlete whose funds are being held. ${ }^{270}$ If a university provided that student-athletes could not, under any circumstances, obtain any payments from these accounts prior to graduation, ${ }^{271}$ then the current collegiate model presumably would be preserved. Unfortunately for the university and the student-athlete, this sort of arrangement poses serious income tax issues.

From the perspective of universities exempt from federal income taxation under section 501 of the Internal Revenue Code, ${ }^{272}$ there is no federal income tax liability incurred for revenues from commercial and promotional uses of student-athlete names and likenesses because these revenues are related to the educational purpose that permits exemption from federal tax liability. In other words, they are not "unrelated business taxable income." 273 By contrast, the revenue is "gross income" 274 to student-athletes.

269 The university - not its charitable foundation-would have to establish the accounts. The charitable foundation could not properly receive and administer funds that were not gifts. The name and likeness payments could not be characterized as gifts.

270 The interest clearly would be income to the student-athlete, see 26 U.S.C. § 61(a)(4) (2012), and the timing of reporting the interest would depend on the rules discussed previously. See supra note 227 and accompanying text.

271 For reasons other than graduation that would permit a student-athlete to gain access to funds held on her behalf, see supra note 220 .

272 Most universities are recognized as exempt from federal and state income taxation under section 501(c)(3) of the Internal Revenue Code. See 26 U.S.C. § 501(c)(3) (2012). Some universities are exempt from federal income taxation under 26 U.S.C. $\S 115$, which provides that "[g]ross income does not include (1) income derived from any public utility or the exercise of any essential governmental function and accruing to a State or any political subdivision thereof, or the District of Columbia." A few universities are subject to federal and state corporate income taxation. See generally RS, IRS EXEMPT Organizations Colleges and Universities Compliance Project (May 7, 2010), available at www.irs.gov/pub/irs-tege/cucp_interimrpt_052010.pdf.

27326 U.S.C. $\S 512$ (2012). A university is exempt from taxes from revenues generated as part of its tax-exempt function but must pay taxes on revenues produced by it that are 
Student-athletes almost certainly are "cash method" taxpayers. ${ }^{275}$ Under both the constructive receipt and "economic benefit" doctrines discussed below, student-athletes would have to report name and likeness revenues as gross income when actually or constructively received by them. It is tempting to conclude that they could wait to report revenues in an income tax return until they actually receive the payments from a university. The Internal Revenue Service might argue, however, that a student-athlete constructively received some or all of the name and likeness revenue when the university placed it in a student-athlete's account, or that placing the revenue in the account created an immediate economic benefit in favor of the student-athlete sufficient to justify immediate taxation to the student-athlete. We discuss both arguments below.

\section{The Constructive Receipt Doctrine}

\section{The Treasury Regulations provide that}

income is constructively received by [a taxpayer] in the taxable year during which it is credited to his account, set apart for him, or otherwise made available so that he may draw upon it at any time, or so that he could have drawn upon it during the taxable year if notice of intention to withdraw had been given. However, income is not constructively received if the taxpayer's control of its receipt is subject to substantial limitations or restrictions. ${ }^{276}$

unrelated to its tax exempt status. For examples of operations with revenue taxed as unrelated business income, see William H. Lyons \& Josephine (Jo) R. Potuto, The Federal Income Tax and Reform of College Athletics: A Response to Professor Colombo and an Independent Critique, 2 J. InTERCOLLEGIATE SPORT 233 (2009). Although the rationale for the position is tenuous at best, under present law, the income produced by the major athletic programs at Division I schools-including any name and likeness revenue component-is not treated as "unrelated business income."

274 Section 61(a) of the Internal Revenue Code defines "gross income," the starting point for computation of federal income tax liability, as "all income from whatever source derived." $\S 61$ (a). There can be no question but that the name and likeness revenues would be "income" and therefore "gross income" to the student-athletes. The revenues might be payment for services under section 61(a)(1) or gains from dealings in property (to the extent that names and likenesses are intangible property interests) under section 61(a)(3).

27526 C.F.R. $\S 1.446-1(\mathrm{c})(1)(\mathrm{i})$ provides:

Cash receipts and disbursements method. Generally, under the cash receipts and disbursements method in the computation of taxable income, all items which constitute gross income (whether in the form of cash, property, or services) are to be included for the taxable year in which actually or constructively received. Expenditures are to be deducted for the taxable year in which actually made.

276 Treas. Reg. § 1.451-2(a) (emphasis added). 
In general, courts have held that a cash method taxpayer need not include compensation in gross income under the constructive receipt doctrine unless: (1) the money was available to the taxpayer; (2) the payor was able and ready to pay; (3) the taxpayer's right to be paid was unrestricted; and (4) the taxpayer's failure to receive the money resulted from an exercise of the taxpayer's own choice. ${ }^{277}$ Thus, a student-athlete likely could escape the constructive receipt doctrine, provided a university made it impossible for the student to receive the revenue payments prior to graduation.

To avoid application of the constructive receipt doctrine to a student-athlete, a university should execute a written agreement with the student-athlete, making clear that (1) money in such an account is not available to the student-athlete prior to his or her graduation; ${ }^{278}$ (2) the university has absolutely no obligation to make distributions to the student-athlete prior to his or her graduation; (3) the studentathlete has absolutely no right to anticipate, assign, borrow against, or receive money from the account prior to his or her graduation; and (4) the student-athlete cannot receive or otherwise benefit from the money in the account prior to his or her graduation ${ }^{279}$ because of an explicit prohibition in the NCAA Bylaws. The agreement should be executed in a timely manner before the period of service for which name and likeness payments are payable. ${ }^{280}$ The safest way to accomplish this goal is to execute these agreements with all studentathletes at the time they matriculate or transfer, regardless of whether there is a reasonable possibility that any particular student-athlete would actually generate name and likeness revenues.

\section{The Economic Benefit Doctrine}

The constructive receipt doctrine comes from the general rule of section 451(a) of the Internal Revenue $\operatorname{Code}^{281}$ governing which

277 See, e.g., Gullett v. Comm'r of Internal Revenue, 31 B.T.A. 1067, 1069 (1935).

278 To be precise, as explained in supra note 232, the agreement should describe the time of disbursement in relation to the conclusion of a student-athlete's university athletic career.

279 See supra note 232.

280 Rev. Proc. $71-19$ § 3.01, 1971-1 C.B. 698 ("If the [deferred compensation] plan provides for an election to defer payment of compensation, such election must be made before the beginning of the period of service for which the compensation is payable, regardless of the existence in the plan of forfeiture provisions." (emphasis added)).

28126 U.S.C. § 451(a) ("The amount of any item of gross income shall be included in the gross income for the taxable year in which received by the taxpayer, unless, under the 
taxable year of inclusion of an item is income. In contrast, the economic benefit doctrine derives from the definition of gross income in section 61(a). ${ }^{282}$ The Internal Revenue Service and courts usually apply the economic benefit doctrine in the context of an employment relationship. Courts typically use the following formulation:

Under [the economic benefit] doctrine, an employer's promise to pay deferred compensation in the future may itself constitute a taxable economic benefit if the current value of the employer's promise can be given an appraised value. ... A current economic benefit is capable of valuation where the employer makes a contribution to an employee's deferred compensation plan which is nonforfeitable, fully vested in the employee and secured against the employer's creditors by a trust arrangement. ${ }^{283}$

The logic of the doctrine is equally persuasive outside the employment context. When translated into the context of the university-established holding accounts, the three key elements of the economic benefit analysis are whether the funds in the accounts are (1) non-forfeitable by the student-athlete, (2) fully vested in the student-athlete, and (3) secured against the university's creditors. The first two criteria would be satisfied because the amounts deposited in the accounts could be structured to be nonforfeitable and to vest fully in the student-athlete. The same is generally true for nonqualified deferred compensation accounts established by employers for employees. ${ }^{284}$ The critical issue for both deferred compensation plans established by employers and university-established holding accounts is the third criterion.

To deal with the third criterion, and to avoid the application of the economic benefit doctrine, employers often leave the source of the deferred compensation subject to the claims of their creditors. Note that the question is not how likely it is that the employer's creditors would actually assert claims against the deferred compensation amounts. Rather, the question is whether the employer's creditors would have the right to do so. The point is that the deferred compensation is at risk from the employer's creditors. Thus, the fact

method of accounting used in computing taxable income, such amount is to be properly accounted for as of a different period.").

$282 \S 61(a)$.

283 Minor v. United States, 772 F.2d 1472, 1474 (9th Cir. 1985).

284 See id. 
that the employee cannot forfeit the compensation is not a controlling factor. $^{285}$

The level of student-athlete risk associated with subjecting amounts in such accounts to the claims of university creditors is not necessarily the same as the employee risk associated with subjecting deferred compensation accounts to the claims of the employer's creditors. As with many employers who establish deferred compensation plans, the actual risk that a university would have large and long-standing unpaid bills prompting creditor lawsuits is probably low. Further, it seems unlikely that university creditors would attempt to reach funds in student-athlete accounts. Not only would this action create a negative public perception, these accounts are also unlikely to contain large deposits, at least when compared to other university accounts. One troublesome point for public universities is that they likely would have sovereign immunity, which would either insulate them from liability - or at least limit the extent of the liability-from creditor lawsuits. In that case, the Internal Revenue Service might argue that the amounts in the student-athlete accounts would essentially be unreachable by creditors and thus subject to the economic benefit doctrine.

In addition to allowing the money in student-athlete name and likeness accounts to remain subject to the claims of the university's creditors, a university might consider other mechanisms to help the student avoid application of the economic benefit doctrine. For example, the university might provide that student-athletes could not assign their rights in such accounts prior to distribution, limiting the ability of the creditors of the student-athletes to reach the money in such accounts prior to distribution. In the employment context, such plans usually provide that employees may not assign their benefits under the plan. Although it is not clear whether such a limitation would offer additional protection to funds in university-established holding accounts for student-athlete name and likeness revenues, it seems prudent for universities to include such a limitation, both by insulating the funds from third-party claims and by explicitly prohibiting student-athletes from assigning their claims.

Because name and likeness revenues would be gross income for student-athletes, ${ }^{286}$ a university would be obliged to prepare and file a

285 Id. at 1485 ("If the employee's interest is unsecured or not otherwise protected from the employer's creditors, the employee's interest is not taxable property so the forfeitability [sic] of the employee's interest is irrelevant." (internal citations omitted)). 
Miscellaneous Income Form (Form 1099-MISC) with the Internal Revenue Service for each student-athlete. ${ }^{287}$ It is unclear whether the university would need to file that form for any taxable year of a student-athlete prior to actual distribution of the money in the account. If neither the constructive receipt doctrine nor the economic benefit doctrine causes a student-athlete to recognize income prior to actual distribution, a university would presumably file a Miscellaneous Income Form only in the year of distribution. A university would be obliged to obtain an Internal Revenue Service Form W-9 ${ }^{288}$ from each student-athlete, or do so-called "backup withholding" of federal income taxes from the revenues. ${ }^{289}$

The fact that the university might create separate accounts to deal with student-athlete name and likeness revenues prior to the studentathletes' graduations without creating tax problems for the institution does not automatically mean that a university would find that approach workable. Public universities subject to audit by the state might find that maintenance of such accounts violates state financial rules. Both public and private universities might find the costs associated with maintaining such accounts to be unacceptable. ${ }^{290}$ Should such problems exist, a university's alternative might be to set

$286 \mathrm{We}$ assume that the student-athletes would not be properly characterized as employees of the university during their playing days, so the university would not be responsible for providing the students with the Internal Revenue Service W-2 forms employers must provide to employees.

287 See Form 1099-MISC, IRS, available at http://www.irs.gov/pub/irs-pdf/f1099msc .pdf (last visited Mar. 11, 2014). The IRS Form 1099-MISC is used by persons who make payments that are income to the recipient. The Form alerts the Internal Revenue Service to the payment and provides the recipient with the information for inclusion on the recipient's federal income tax return

288 See Form W-9, IRS, available at http://www.irs.gov/pub/irs-pdf/fw9.pdf (last visited Mar. 11, 2014).

289 "Backup withholding" is a flat percent rate applied to the amount of income paid to a taxpayer, which is currently twenty-eight percent. 26 U.S.C. $§ 3406$ (2012). The taxpayer can treat the amount withheld as a credit toward federal income tax due. 26 U.S.C. $\S$ 6401(b)(1). Backup withholding is a device to ensure the recipient of taxable income will in fact pay the tax due on that income. Backup withholding is not an employment concept and is usually used for payments of interest, dividends, and nonemployee compensation. See 26 C.F.R. § 31.3406(a)-4 (2014). In the context of the accounts for the studentathletes, the withholding would be based on the amount in the account immediately before distribution. The distribution to the student-athlete would be the amount in the account reduced by the amount of withholding. A state with an income tax might also require backup withholding of state income tax.

290 If the NCAA expressly approves of such accounts, the persuasiveness of the university's arguments against using such accounts based on their cost and associated inconvenience would be of limited value. As noted in text, however, there may be other potentially significant reasons for universities to resist use of such accounts. 
up a private express trust to receive, hold, and disburse name and likeness payments.

\section{B. Private Express Trust ${ }^{291}$}

The purpose would be to receive student-athlete name and likenesses payments, hold them until the student-athletes graduate, ${ }^{292}$ and then disburse the payments to them.

\section{Trust Law Issues}

Presumably, a university could establish a private express trust despite the lack of donative intent in creating the trust. ${ }^{293}$ It is unclear whether the university itself could act as trustee of the trust. ${ }^{294}$ To avoid possible problems created if the university acted as trustee, the university most likely should employ a corporate trustee. Using a corporate trustee would not, however, eliminate collateral problems. For example, the corporate trustee's fees for managing the trust property could be significant and would be payable from the income or the principal of the trust - or both - thus diminishing the amounts ultimately payable to student-athletes. To avoid having the name and likeness payments eroded by inflation while the student-athletes are in school, the trustee should have the power to invest the payments. Exactly how the trustee would invest the payments to prevent loss from inflation, yet avoid or at least minimize investment losses that would diminish what the student-athletes would receive, would require careful drafting of the trust document. The trustee should also have the power to maintain separate accounts for each student-athlete,

291 The word "private" in the term "private express trust" distinguishes trusts established for private, as opposed to public, purposes. The word "express" distinguishes between arrangements established either orally or in writing as trusts, as opposed to equitable remedies, such as the "constructive trust" or "resulting trust."

292 To be precise, as explained supra note 232, the trust instrument should describe the time of disbursement in relationship to the conclusion of the student-athlete's university athletic career.

293 Although the principal use of private express trusts in the United States is to accomplish donative transfers, private express trusts are also used for other purposes. For example, a private express trust could be established to receive and administer a judgment or settlement in a personal injury case. "A trust may be created only to the extent its purposes are lawful, not contrary to public policy, and possible to achieve. A trust and its terms must be for the benefit of its beneficiaries." Unif. Trust Code $\S 404$ (emphasis added).

294 Whether a university could act as a trustee of a private express trust would depend on the university's charter and on the laws of the state in which the university is situated. 
yet manage the entire fund as a unit to obtain the maximum flexibility for investing.

Use of a private express trust to hold the name and likeness payments may not be a viable option in many states because of the Rule Against Perpetuities (RAP). ${ }^{295}$ Although a number of states have either repealed or limited the RAP as it applies to private express trusts, a majority of states still have some version of the RAP. In those states, the trust here described would almost certainly violate the RAP because the trust would have new beneficiaries each year, and at some point the interests of the new beneficiaries would vest beyond the period of the RAP, however computed. ${ }^{296}$

\section{Income Tax Issues Associated with Using a Trust}

As previously noted, most universities would pay no federal income tax on name and likeness revenues. Similarly, student-athletes would pay no income tax on their name and likeness revenues held by a trust until the revenues were distributed to them. Nonetheless, there are distributive tax consequences to student-athletes.

Application of these income tax rules is relatively straightforward. The revenue deposited in a trust would be income to the trust when received. ${ }^{297}$ In addition, any income earned by the trust from

295 The RAP, first articulated in England in a series of cases starting with the Duke of Norfolk's Case, 3 Ch. Cas. 1, 22 Eng. Rep. 931 (1682), which was developed to diminish the decedent's ability to limit transferability of his or her property in perpetuity. Professor John Chipman Gray stated the United States version of the rule in the following way: "No [non-vested property] interest is good unless it must vest, if at all, not later than twentyone years after some life in being at the creation of the interest." JOHN CHIPMAN GRAY, The Rule Against Perpetuities vii (2d ed. 1906). Although the RAP has undergone significant changes in the United States since 1906, many states still retain some form of the RAP.

296 The Uniform Trust Code permits creation of trusts that avoid the RAP because they exist for a limited period (the Uniform Trust Code specifies twenty-one years). Such trusts, however, are for animals and other purposes not involving human beneficiaries, such as maintenance of monuments or buildings.

297 Section 117 of the Internal Revenue Code, the exclusion for "qualified scholarships," would not apply because the student-athlete could not satisfy the "use" requirement ("[t]he term "qualified scholarship" means any amount received by an individual as a scholarship or fellowship grant to the extent the individual establishes that, in accordance with the conditions of the grant, such amount was used for qualified tuition and related expenses." (emphasis added)). Repaying a loan used to pay "qualified tuition and related expenses" using money distributed by the trust would not satisfy the use requirement in the statute. 
investing the revenue would be income to the trust. ${ }^{298}$ Unless Congress were to create an exemption from federal income taxation specific to these trusts, ${ }^{299}$ the trust would be a taxpayer subject to the graduated tax rates set forth in section 1(e) of the Internal Revenue Code. ${ }^{300}$ The trust would be set up to distribute neither the name and likeness payments nor any interest or investment income on payments to the student-athlete until after his graduation. The trust would compute tax liability and pay taxes annually.

The name and likeness revenue and any investment income earned on that revenue would be taxed both when received by the trust and when the benefit conferred by the trust (avoiding problems with NCAA rules) justifies the "toll charge" of the higher rates paid by the trust. When a trust subsequently distributes the taxed name and likeness payments and any income from investment to the studentathletes, the student-athletes would pay taxes on any income earned during the year of distribution but would not be taxed on the portion of the distribution that was previously taxed to the trust.

If the trust receives payments relating to multiple student-athletes, the trustee could establish separate accounts for each student-athlete. Trusts can and do use separate accounts for individual beneficiaries, although that approach increases administrative costs. The trust should still be able to file a single fiduciary income tax return despite having multiple beneficiary accounts.

The problem for student-athletes is that this straightforward application of Internal Revenue Service rules also means that taxes on their funds held in trust will, in all likelihood, be significantly greater than if student-athletes had reported the payments annually in their own individual tax returns. ${ }^{301}$ The name and likeness revenue must be treated as ordinary income, as opposed to capital gain, whether it is treated as self-created intangible property or payment for the student-

298 Under 26 U.S.C. $\S 61$ (a), the trust would be required to include as income interest ( $§$ $61(\mathrm{a})(4))$, dividends $(\S 61(\mathrm{a})(7))$, gains from dealings in property (section 61(a)(3)), and any other "income" the trust might receive.

299 Under present law, the trust could not qualify for an exemption from federal income tax under section 501 of the Internal Revenue Code. Congress could create a new exemption for such trusts, but there is no sound tax or social policy support for such an exemption.

30026 U.S.C. $\S 1(\mathrm{e})$.

301 Compare the tax rate brackets in 26 U.S.C. $\S 1$ (a) (married filing jointly), (b) (head of household), and (c) (unmarried), with the tax rate brackets in 26 U.S.C. § 1(e) (estates and trusts). 
athlete's services. ${ }^{302}$ Thus, the trust would not receive the special reduced tax rate reserved for long-term capital gain. ${ }^{303}$ The significantly greater tax payments result from the fact that the rate brackets for trusts, although adjusted annually for inflation, are very compressed in comparison with the brackets for individuals. ${ }^{304}$

Special problems exist if a student-athlete is not a United States citizen. The tax treatment would depend, in part, on whether the United States and the student-athlete's home country have entered into a tax treaty. Those problems are beyond the scope of this Article.

\section{Resolving the Quandary}

As discussed above, a public university may be unable or unwilling to hold funds outright and may also be unable to create a trust to avoid providing earned name and likeness revenues to studentathletes. Should NCAA bylaws ultimately permit student-athletes to share such revenues after student-athletes graduate, those states could be on the horns of a dilemma.

One solution, of course, would be for those states either to adjust their financial audit rules or to legislatively change their approach to the RAP. One can argue that for purposes of the RAP, there is no good policy justification to treat student-athlete trusts differently from other private express trusts. More importantly, the unseemly rush in certain states to limit or eliminate the RAP simply to accommodate

302 See 26 U.S.C. $\S 1221$ (a)(3), which provides that the term "capital asset" does not include: "a copyright, a literary, musical, or artistic composition, a letter or memorandum, or similar property, held by . . . a taxpayer whose personal efforts created such property ...."Id

30326 U.S.C. $\S 1$ (h) (net long-term capital gain taxed at a rate not in excess of twenty percent).

304 For 2013, the rate brackets in $\S 1(\mathrm{e})$ are:

If taxable income is:

Not over $\$ 2,450$

Over $\$ 2450$ but not over $\$ 5700$

Over $\$ 5700$ but not over $\$ 8750$

Over $\$ 8750$ but not over $\$ 11,950$

Over $\$ 11,950$
The tax is:

$15 \%$ of the taxable income

$\$ 367.50$ plus $25 \%$ of the excess over $\$ 2450$

$\$ 1180$ plus $28 \%$ of the excess over $\$ 5700$

$\$ 2034$ plus $33 \%$ of the excess over $\$ 8750$

$\$ 3090$ plus $39.6 \%$ of the excess over $\$ 11,950$

By contrast, in 2013, an unmarried individual who is not a head of household or surviving spouse would not be subject to the $39.6 \%$ bracket until she had taxable income in excess of \$400,000. Internal Revenue Bulletin: 2013-5, IRS (Jan. 28, 2013), available at http://www.irs.gov/irb/2013-05_IRB/ar06.html. 
federal wealth transfer tax planning should remind legislatures in other states to proceed with caution in amending the RAP. ${ }^{305}$

Congress could also resolve the quandary by creating a special tax bracket system for student-athlete trusts to treat the trusts, in effect, as unmarried human taxpayers. There seems to be no sound tax policy justification for creating such a special regime, and no social policy justification either. An alternative might be to create the equivalent of trust "throw-back" rules. ${ }^{306}$ Under that alternative, the trust would pay income tax annually until a student-athlete's graduation. Upon distribution, student-athletes would compute their taxes on the distributed income at their own rates for the distribution year and would receive a tax credit for tax payments previously made by the trust. Such an alternative would also require congressional action. Like the special rate rule mentioned earlier, there appears to be neither a tax policy justification nor a social policy justification for such an alternative.

An alternative that might require no adjustment to the general operation of public university policies would be for either the NCAA or the conference to which a university belongs to administer a holding fund or trust. Such an alternative would likely raise the same federal tax issues already discussed. ${ }^{307}$

305 When Congress added the federal Generation-Skipping Transfer Tax (GSTT) in 1986, it probably did not envision that people would couple the intended limitation on the application of the tax (a one million dollar exclusion that would, in effect grow as trust property increased in value over time) with the limitation or repeal the RAP. The result, popularly known as the "dynasty trust," allows large transfers of wealth from generation to generation without federal wealth transfer taxation until the trust terminates. Because the elimination of the RAP alleviates the need to terminate the trust, the trust can continue indefinitely.

30626 U.S.C. $\S \S 665-68$. The throw-back rules originally applied to all trusts that distributed accumulated income, but have essentially applied only to foreign trusts, since the Taxpayer Relief Act of 1997. The throw-back rules, as applied to domestic trusts, were intended to discourage trusts from accumulating income for many years as relatively low trust income tax rates, rather than distributing the income to beneficiaries who were in higher tax brackets. The Internal Revenue Service treated actual distributions of accumulated trust income as all earned in the year of distribution and to force a beneficiary to include all the income on his or her tax return, if the beneficiary's average marginal tax rate in the previous five years was higher than the tax rate of the trust. The 1997 legislation instituted the narrow trust tax brackets for domestic trusts and thus eliminated the need to apply the throwback rules to most domestic trusts.

307 Whether some of the same state trust law issues also would arise depends on the state in which the funds would be administered. 
A very partial solution is available to avoid tax, trust, state, and university policy issues. As previously described, ${ }^{308}$ the NCAA distributes revenues through the conferences to the campuses to be made available through athletic department administration of a Student-Athlete Opportunity Fund (the Fund). In White v. NCAA, ${ }^{309}$ a class of FBS football and men's basketball student-athletes challenged NCAA's scholarship limits. ${ }^{310}$ Pursuant to a settlement in White, the NCAA added to the monies to be distributed through the Fund. ${ }^{311}$ Were a share of NCAA and conference revenues allocated to the Fund, more money would reach the hands of student-athletes while they are student-athletes. However, this alternative would likely require that student-athlete uses of the Fund would be tied to particular expenses derived from their student status. Moreover, the total amount allocated to each student-athlete would not reach the revenue amounts that the Keller/O'Bannon plaintiffs claim is owed to them.

$\mathrm{X}$

THE DRIFT IN THE COLLEGIATE MODEL

The commercialization of athletic departments is part and parcel of the commercialization of the universities to which they belong. Both are propelled by the need to find revenue to support operations.

\section{A. How Revenue Is Generated}

Not all revenue streams can or should be pursued if principle, not simply principal, is to govern. Obvious examples are corporate sponsors whose products or services are incompatible with intercollegiate athletics and campus values - alcohol, including beer

308 See supra note 104 and accompanying text

309 White v. NCAA, No. CV 06-999-RGK (MANx), slip op. at 3 (C.D. Cal. Sept. 20, 2006).

310 Jack Carey \& Andy Gardiner, NCAA Agrees to \$10M Settlement in Antitrust Lawsuit, USA TODAY (Jan. 30, 2008, 12:03 PM), http://usatoday30.usatoday.com/sports /college/2008-01-29-ncaa-settlement_N.htm.

311 The additional money was available for a five-year period from 2008 to 2013. For the full terms of the settlement, see Stipulation and Agreement of Settlement Between Plaintiffs and Defendant National Collegiate Athletic Association, Case No. CV06-0999 VBF (MANx), White v. NCAA (C.D. Cal. Jan. Jan. 29, 2008), available at http://i.usatoday.net/sports/college/2008-01-29-ncaa-settlement.pdf. At the time of the White settlement, the fund was called the "Student-Athlete Assistance Fund." 
and wine; tobacco and cigarettes; ${ }^{312}$ and overtly sexual content. These, however, are only starting points for discussion.

\section{Merchandise, O.K.}

Athletic departments and the NCAA operate both onsite and webbased merchandise outlets. Universities, conferences, and the $\mathrm{NCAA}^{313}$ sell items with their names and logos on them. They sell exclusive licenses to Coke or Pepsi, Dr. Pepper or Fresca, Pizza Hut or Chick-fil-A, so that only that product may be sold in their buildings and at their venues. ${ }^{314}$ They sell exclusive licenses to Nike or Adidas or other clothing and equipment merchandisers to be the only "official" apparel that may bear an NCAA, conference, or university name or $\operatorname{logo} .^{315}$ In addition, universities and - until recently - the NCAA sold apparel and other items on which player numbers are affixed. ${ }^{316}$ All of these activities seem unremarkable.

There are also university agreements with Nike or Adidas by which they receive team uniforms and equipment without charge; these deals can be worth more than $\$ 2$ million. ${ }^{317}$ They are problematic because student-athletes wear the uniforms and use the equipment during games and at practices. The quid pro quo for the merchandiser is that its logo or design appears on the uniforms.

NCAA bylaws regulate the size and placement of logos and designs not only on uniforms ${ }^{318}$ and equipment ${ }^{319}$ used by student-

312 The NCAA prohibits alcohol, cigarette, or gambling advertisements in conjunction with NCAA championships. NCAA MANUAL, supra note 1 , § 31.1.14.1. On the other hand, wine and beer products with less than six percent alcohol content are permitted if they take up less than fourteen percent of program space or no more than sixty seconds per hour of air time. Id. $\S 31.1 .14 .1 .1$. No alcohol of any kind may be sold at a championship venue. Id. § 31.1.15.

313 Dennis Dodd, NCAA to 'Exit' Business of Selling School-Related Online Items, CBSSPORTS.COM (Aug. 8, 2013, 3:54 PM), http://www.cbssports.com/collegefootball /blog/dennis-dodd/23070728/ncaa-to-exit-business-of-selling-schoolrelated-online-items.

314 See supra note 69.

315 For an example of an exclusive merchandise license, see the sponsorship agreement between Nike and the University of Arizona, available at http://media.oregonlive .com/pac10/other/Arizona-State-Nike-Sponsorship.pdf.

316 See infra notes 362-64 and accompanying text.

317 Kristi Dosh, Montana Finds Cost-Effective Ways to Compete on Uniform Front, BUS. C. SPORTS (Oct. 29, 2013), http://businessofcollegesports.com/2013/10/29/montana -finds-cost-effective-ways-to-compete-on-uniform-front/.commentators.

318 NCAA MANUAL, supra note 1, § 12.5.4; Cork Gaines, Nike Made Top College Football Coaches Return Apparel that Didn't have Enough Swooshes, BUS. INSIDER (Sept. 6, 2013, 2:55 PM) (describing Nike apparel recall because swoosh not sufficiently 
athletes, but also on uniforms for bench personnel, ${ }^{320}$ band members, spirit squads, dance teams, and university mascots. ${ }^{321}$ The revenues generated through these apparel deals, together with prescribed limits on logo size and placement, lead to the conclusion that they should be accommodated in the collegiate model even though the consequence is that student-athletes effectively are models for the uniforms.

\section{Merchandise, Not O.K.}

Some teams wear shoes from a particular shoe manufacturer because the head coach, typically in basketball, ${ }^{322}$ has an endorsement deal. ${ }^{323}$ Shoes worn by all team members are not associated with individual student-athletes. Shoes, moreover, have no logos. They are discernible, if at all, because of their style. These shoe deals would be unexceptionable, therefore, were the contract with a university, even if all the profits derived from them were allocated to a particular head coach's salary. The deals also might be worth less money, however, if they included no coach's public endorsement. Often, although not exclusively, less-resourced schools permit head coach endorsement deals as ways to augment a coach's salary. ${ }^{324}$ Nonetheless, a coach's personal endorsement deal, and consequent

visible). Shoe deals can be particularly problematic, given the relationship of manufacturers with high school (and grade school) basketball teams unassociated with educational institutions. Tom Gieryn, Is It All in the Shoes?, DuKE CHRON. (Oct. 3, 2012), http://www.dukechronicle.com/articles/2012/10/04/it-all-shoes.

319 NCAA MANUAL, supra note $1, \S$ 12.5.4. Equipment includes shoes, helmets, skis, bats, hockey, and lacrosse sticks.

320 Id. $\S 31.1 .7$.

321 Id. $\S 31.1 .8$.

322 Steve Wieberg \& Jodi Upton, Success on the Court Translates to Big Money for Coaches, USA TODAY (Mar. 8, 2007), http://usatoday30.usatoday.com/sports/college /mensbasketball/2007-03-08-coaches-salary-cover_N.htm.

323 BYERS, supra note 2, at 9-10; ZIMBALIST, supra note 8, at 137. Jerry Tarkanian, the head men's basketball coach at the University of Nevada-Las Vegas, received a free pair of shoes for every pair he bought for the team. ZIMBALIST, supra note 8, at 137. Deals that funnel benefits to coaches or athletic department staff are not confined to head coach shoe deals. See, e.g., Lewis Kamb, Big-Time Coaches Score Big-Time Perks, SEATTLE TIMES (Nov. 23, 2013, 3:55 PM), http://seattletimes.com/html/localnews/2022321329_coaches payxml.html. Head coaches and senior athletic department staff receive free golf club memberships. Id. They routinely are provided automobiles by corporate sponsors and donors, including loaners at away games. Id. They have access to private charters. Id. Those benefits are often included in head coach contacts. Id. Head coaches also market their athletic reputations by participating in commercials or acting as color commentators to games when their competition seasons are over.

324 Mark Yost, Who Pays the College Coach, Wall ST. J. (Dec. 6, 2008, 11:59 PM), http://online.wsj.com/news/articles/SB122853304793584959. 
direct profit, from shoes his team wears makes these deals indefensible under a collegiate model.

\section{Advertisements, O.K.}

Advertisements are videos streamed on ribbon boards at university competitions and conference and NCAA championships. Names of corporate sponsors circle stadiums and arenas while commercial messages are displayed on big screens during games. FBS athletic department websites are replete with advertisements. These may be unappreciated by fans, but again they seem relatively unremarkable ways to produce revenues.

\section{Advertisements, Not O.K.}

Another commercial use engaged in at least by the NCAA is the inclusion of advertising on DVDs, webcasts, and photographs featuring individual student-athletes and former student-athletes. Examples are video streaming of ads on website video clips and on DVDs of famous plays that showcase and name individual studentathletes $^{325}$ as well as advertisements on pictures of individual players taken during a game. ${ }^{326}$ There is a substantive difference between NCAA sales of DVDs that depict a game, a series of famous game plays, or student-athlete pictures taken during a game and the same depictions that also contain advertisements. The practice should be discontinued.

\section{Media Contracts, O.K.}

Commercial networks regularly televise football and men's basketball games. Competitions in other sports also are televised, although typically on a more limited, and often more local, basis. Commercials interrupt the flow of competition. Yet, no critic suggests that telecasts and other real-time video dissemination of competitions with commercial breaks should be prohibited outright because they commercialize intercollegiate athletics or because they offend the

325 Third Consolidated Amended Class Action Complaint, supra note 147, at 48. One such example involves McDonalds ads that run on the bottom half of video clips that depict plays with identified student-athletes. Id. at 70 .

326 One such example involves a photo of former men's basketball student-athlete and NBA star Oscar Robertson. Id. at 24. 
collegiate model. ${ }^{327}$ If live telecasts are consistent with the collegiate model and offend no student-athlete legal entitlement, then DVD sales of games or of famous plays and telecasts of archived game footage seem an appropriate offshoot of the authority to broadcast in the first instance.

\section{B. Wink, Wink}

As discussed in Part IV, NCAA bylaws formally describe a narrow area in which the NCAA, conferences, and universities may use student-athletes, or their names and likenesses, in commercial ventures. In line with these bylaws, the NCAA license granted to EA Sports was a license to use the NCAA name and logo, not a license to use student-athlete names and likenesses in the game. The courts will decide whether the NCAA's knowledge of how EA Sports produced the games, and its evident failure affirmatively to police restraints on what EA Sports might do in the games, ${ }^{328}$ triggered legal responsibility for the use of student-athlete names and likenesses; and, if so, whether student-athletes should be paid. Even if the NCAA prevails on its legal claim, however, that by no means ends the story.

Although the NCAA relied on outsourcing the responsibility to assure EA Sports's compliance with NCAA amateurism bylaws as part of its defense in the Keller/O'Bannon litigation, ${ }^{329}$ the NCAA cannot credibly claim that it had no knowledge that EA Sports used avatars and a computer application. In fact, in 2004, Collegiate Licensing Company (CLC) advised the NCAA to permit greater verisimilitude in the games to protect sales revenue. ${ }^{330}$ The 150 institutions and conferences that, through CLC, extended their licenses with EA Sports ${ }^{331}$ did so in the midst of media coverage of

327 The Supreme Court has prohibited NCAA bylaws that limit team broadcast appearances. See NCAA v. Bd. of Regents, 468 U.S. 85 (1984).

328 In line with what is required of conferences and institutions by the NCAA Manual, EA Sports agreed in writing to abide by applicable NCAA bylaws. See NCAA MANUAL, supra note $1, \S \S 32.4 .18 .1,3.3 .4 .7 .1$; Complaint for Damages, Declaratory Relief, and Jury Demand, supra note 58, at 4. The NCAA has now sued EA Sports and CLC for indemnification from any damages award and also for attorney fees. Complaint for Damages, Declaratory Relief, and Jury Demand, supra note 58, at 4.

329 Complaint for Damages, Declaratory Relief, and Jury Demand, supra note 58, at $11,13,26$.

330 Third Consolidated Amended Class Action Complaint, supra note 147.

331 The number also included some bowls. The game was to be called "College Football" rather than "NCAA Football." Brent Schrotenboer, EA Sports Re-Ups on College Football After NCAA Snub, USA TODAY (July 19, 2013, 8:30 PM), http://www 
the Keller/O'Bannon lawsuit. They certainly cannot credibly claim ignorance of the nature of the EA Sports videogame.

A fundamental obligation under the collegiate model should be to avoid the use of student-athlete names and likenesses in commercial ventures or promotions both directly, and also indirectly through actions of corporate partners that can be anticipated and prevented by due diligence. Principled and consistent application of the amateurism principle, particularly by higher education leaders, demands more than a closed-eye or "wink, wink" approach. Examples abound. ${ }^{332}$

Consider that, until recently, the NCAA marketed school-related apparel and memorabilia on a website that handled NCAA merchandise sales. ${ }^{333}$ The NCAA sold Texas A\&M football jerseys that sported player number "2," the uniform number of Texas A\&M quarterback Johnny Manziel. To locate a number " 2 " Texas A\&M jersey, a purchaser need only type "Johnny Manziel" into the website's search engine. ${ }^{334}$ A purchaser could also type "Terrelle Pryor" into the search engine to find and purchase a jersey with Pryor's Ohio State player number. ${ }^{335}$ Among other items, the website also featured an autographed photograph of former University of Southern California football athlete Reggie Bush. ${ }^{336}$ These latter two instances are particularly indefensible as both Pryor and Bush were

.usatoday.com/story/sports/NCAAf/2013/07/19/ea-sports-college-football-contract -renewed/2570119/.

332 Television broadcasts at one time touted the CBS Chevrolet Player of the Game at Men's Basketball Tournaments. See Troy Bell: As a Sophomore, Boston C., http://www .bceagles.com/sports/m-baskbl/mtt/troy_bell_15731.html (last visited Mar. 11, 2014). On official athletic department websites, universities encourage fans to vote for the Pontiac Game Changing Performance of the Year, with award money going to the university at which the winning student-athlete competed. E.g., Vote for University of Maryland's 'Pontiac Game Changing Performance' and the Terrapins Could Win \$5,000, MD. ATHLETICS (Nov. 13, 2006), http://www.umterps.com/ViewArticle.dbml?\&DB OEM ID $=29700 \&$ ATCLID=207291703; Vote for Ronnie Palmer in the Pontiac Game Changing Performance, ARIZ. ATHLETICS (Nov. 13, 2006), http://www.arizonawildcats.com/View Article.dbml?DB_OEM_ID=30700\&ATCLID=207926126.

333 Dodd, supra note 314.

334 Laken Litman \& Steve Berkowitz, NCAA Apparel Sales Site Used Athletes' Names in Search, USA TODAY (Aug. 7, 2013, 12:55 PM), http://www.usatoday.com/story/sports /ncaaf/2013/08/06/ncaa-shop-search-football-jerseys-johnny-manziel/2625119/. Other examples of the operation of the search engine are Jadeveon Clowney of South Carolina and Braxton Miller of Ohio State. Id.

335 Id.

336 Id. 
central figures in major infractions cases involving their universities. $^{337}$

\section{Outsourcing}

Outsourcing licensing and general marketing responsibility is a cost-effective way to market inventory and locate new revenue streams. ${ }^{338}$ But outsourcing the marketing arm distances these decisions from the campus environment or direct campus or NCAA control. ${ }^{339}$ The result is that financial gain is more likely to be the only, or at least the prime, interest advanced. ${ }^{340}$

Either the NCAA, conferences, and universities mean what they say about their obligations under the collegiate model, or they do not. In this case, moreover, principle is matched to prudence. Continuing activities like the ones described above risks further litigation and certainly will not still the drums of complaints.

\section{Policing}

Currently, the Division I Championships Cabinet reviews media rights contracts related to NCAA championships. ${ }^{341}$ The NCAA executive committee, comprised of presidents and chancellors from all three NCAA divisions, has specific authority to seek detailed information regarding NCAA commercial activities. ${ }^{342}$ The Division I Board and Leadership Council may request information regarding

337 Ohio State University Infractions Report No. 358 (2011); University of Southern California Infractions Report No. 323 (2010). As NCAA President Mark Emmert rightly put it, "We certainly recognize why that could be seen as hypocritical. ... Indeed, the business of having the NCAA in those kinds of goods is a mistake. We're going to exit that business immediately. It's not something core to what the NCAA is about. We probably never should have been in that business." Dodd, supra note 314 .

338 See Dodd, supra note 314.

339 It also may be true that universities, conferences, and the NCAA are more inclined to permit commercial uses as ways to increase the license fee paid. One example may be the increase in the number and length of commercials during broadcast games. Although more and longer commercials during broadcasts may have occurred regardless, some have been attributed to a quid pro quo for the large broadcast fees. See, e.g., BYERS, supra note 2.

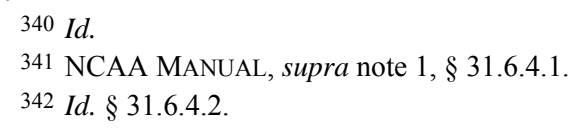


commercial ventures. ${ }^{343}$ That oversight is neither regular enough nor focused enough. ${ }^{344}$

To assure that principle trumps principal, there should be a very clear set of guidelines that articulate permissible marketing and promotional activities. On campus, there should be regular discussions between the athletic department and representatives of the greater campus regarding the appropriate nature and scope of commercial ventures. The NCAA should form a committee of representatives from NCAA institutions to oversee NCAA marketing and promotional decisions and to conduct annual reviews of the nature and scope of all commercial ventures. It may be unwieldy to review all such contracts as they develop and perhaps even before they are signed, but annual quality audits should be conducted. Such vigilance is needed to offset the otherwise compelling allure of revenue production, no matter its source or scope, and the consequent continuing threats to the viability of the collegiate model.

\section{How Money Is Spent ${ }^{345}$ and Exempt Status for Federal Income Tax Purposes}

As previously described, to acquire tax-exempt status, an educational institution must be organized and operated for exclusively educational purposes. This requirement seems to be met for athletic programs when a university administers varsity athletic competition as part of the overall university mission or treats varsity athletic competition as itself an educational experience. ${ }^{346}$

When revenues generated by athletic departments go to support the campus generally, the educational purpose is eminently clear. When revenues generated by athletic departments go to fund forty sports and academic support staffs to assure student-athletes succeed academically and graduate, again, the educational purpose is clear. When revenues generated by athletic departments provide varsity

\footnotetext{
343 Id.

344 The NCAA's claim that CLC should have exercised oversight of the contours of the EA Sports video game underscores the need for closer and more direct NCAA supervision. See infra notes 293-95 and accompanying text.

345 In the following section, we examine how use of revenue generated by a university exempt from income taxation under section 501(c)(3) of the Internal Revenue Code could affect retention of that tax-exempt status. This question is not the same as the question of whether money received by a tax-exempt university constitutes "unrelated business income" subject to the "unrelated business income tax."

346 Lyons \& Potuto, supra note 273, at 234-39.
} 
athletic opportunities to large numbers of student-athletes, then the educational purpose also seems relatively clear. By contrast, if revenues generated by athletic departments support student-athletes in sixteen sports, with the bulk of revenues directed at building athletic palaces, paying big salaries to coaches and other athletic personnel, and otherwise spent on items with little direct benefit to students or student-athletes, then that is another matter entirely. ${ }^{347}$

IX

A NEW PARADIGM

\section{A. Doing More for Student-Athletes}

Consistent with the collegiate model, there are a number of things that might be done to enhance the experience of student-athletes and direct more benefits to them. The following sections briefly discuss some of these items, simply as placeholders indicating the type of reforms that could have a discernible impact on the treatment of student-athletes without triggering a paradigm shift in the collegiate model.

\section{Educational Aid}

Nothing is more central to the collegiate model than optimizing a student's opportunity to get a degree. Also important is optimizing the opportunities to pursue postgraduate or professional educational opportunities. The most important set of reforms, therefore, is in scholarship support. First, scholarships should be funded to the full cost of attendance ${ }^{348}$ rather than capped at tuition, room and board, and books. A second reform would be to make all sports head count sports. As noted previously, football and men's basketball are two of

347 Way back in 1969, the recruitment of a high profile men's basketball student-athlete could cost twenty-five thousand dollars. BYERS, supra note 2, at 220.

348 We recognize that full-ride scholarships are not fully excludable as scholarships under section 117 of the Internal Revenue Code. Since the Tax Reform Act of 1986, only that portion of a scholarship grant actually used by the recipient for tuition, books, lab fees, and similar expenses qualifies for the exclusion. Any portion of a scholarship used by a student for other costs, including but not limited to room and board, represents gross income that the recipient must report on his federal income tax return. That Congress, for tax policy reasons, has elected to make a portion of a scholarship taxable does not undercut our argument that athletic scholarships should all be full-ride grants. The tax consequences of receiving a full-ride scholarship are the same for all students (other than foreign nationals), regardless of whether they receive the scholarships in recognition of athletic ability, academic merit, or financial need. 
only five NCAA head count sports. ${ }^{349}$ Under the collegiate model, the quid pro quo for athletic participation is a scholarship and a college degree. Student-athletes in equivalency sports work as hard as their counterparts in football and men's basketball. Their commitment is just as serious. Their scholarship support also should be the same. Equating educational support with revenues produced by that sport is inconsistent with the collegiate model.

A third reform would be to enhance the NCAA post-graduate scholarship program. ${ }^{350}$ There should be more postgraduate scholarships awarded, for larger amounts, and for more than one year. $^{351}$

\section{Fair and Equitable Treatment}

\section{a. Transfers}

There are many sound reasons for NCAA bylaws that discourage transfers by imposing eligibility or scholarship consequences, not the least of which are data that show that student-academic performance suffers and graduation is less likely. Nonetheless, except for intraconference transfers, ${ }^{352}$ transfer restrictions should be eliminated. Students, including student-athletes, sometimes make bad decisions about where to attend school. If a student-athlete is unhappy with his athletic department, treatment by a coach, or situation at a university-whether the reasons are well-founded or not-the student-athlete should be able to transfer to find a better fit. ${ }^{353}$ The

\footnotetext{
349 See supra notes 221-22 and accompanying text.

350 In addition, a review should be conducted of the number of NCAA degreecompletion scholarships to assure that the number is adequate to cover student-athletes whose failure to achieve a degree was not due to clear shirking of their academic work when initially enrolled.

351 Postgraduate scholarships should be available at least to any letter winner who achieves a 3.70 or higher grade point average. Additionally, the scholarship amount should be increased from $\$ 7500$ to $\$ 10,000$. The scholarship should also cover at least two postgraduate years, subject to the students' achievement of a stated minimum grade point average in the first year.

352 Intra-conference transfers involve increased opportunities for tampering, more compelling coach concerns about facing a former student-athlete in competition (knowing playbook, etc.), and the intra-conference need for continuing member cooperative interaction that might be affected by tampering concerns.

353 An alternative to eliminating all restrictions, therefore, would be to limit transfers in a student-athlete's first two years of enrollment.
} 
fact that coaches can walk out on contracts seemingly at will only exacerbates the perception that student-athletes are treated unfairly. ${ }^{354}$

\section{b. Oversigning}

A prospective student-athlete who signs a national letter of intent $(\mathrm{NLI})^{355}$ thereby declines the opportunity to attend another university and compete. His announced intention to sign an NLI may discourage other schools from continuing to recruit him, particularly if he is not a prime recruiting target. If at or near signing day a coach pulls the scholarship offer, that prospective student-athlete may have little or no viable options, and certainly will have fewer of them than he had earlier in the recruitment period. Of course, prospective studentathletes have been known to de-commit at the last moment. ${ }^{356}$ That means that a coach needs some "play in the joints" in making scholarship offers as he cannot project with certainly what will happen among all commits on signing day. Nonetheless, some of the reported coach behaviors ${ }^{357}$ go well beyond the need to account for potential de-commits and instead seem designed to provide a large pool of commits from which a coach may then choose the most talented to fill his recruiting class. However limited this practice may be, it must stop. It is not fair to those recruits who ultimately are boxed out. ${ }^{358}$

\section{c. Play/Practice Limits}

College athletic participation is part of a student-athlete's university experience but should not engulf it. NCAA bylaws limit the number of required hours that student-athletes may devote to a

354 Taylor Branch, The Shame of College Sports, ATLANTIC (Oct. 2011), http://www.theatlantic.com/magazine/archive/2011/10/the-shame-of-college-sports /308643/.

355 The NLI program is administered by the NCAA. See The National Letter of Intent, NCAA.ORG, http://www.ncaa.org/about/resources/media-center/national-letter-intent (last visited Mar. 12, 2014). For signing dates by sport for 2013 to 2014, see NLI Signing Dates for Prospective Student-Athletes Enrolling 2014-15, NLI, http://www.nationalletter.org/ (last visited Mar. 12, 2014).

356 See Luke Winn, The Commitment Project: A Study of Top-100 Recruit Behavior, SI.COM (Aug. 5, 2011, 11:15 AM), http://sportsillustrated.cnn.com/2011/writers/luke winn/08/01/commitment.trends/.

357 See Grant Freking \& Jimmy Oldham, Oversigning: Football's Latest Overindulgence, LANTERN (Jan. 31, 2011), http://thelantern.com/2011/01/oversigning -footballs-latest-overindulgence/.

$358 \mathrm{We}$ do not suggest that it will be easy to identify by regulation between acceptable and unacceptable oversigning, but the effort must be made. 
sport, ${ }^{359}$ but they do not attempt to constrain student-athlete voluntary time. A student-athlete may not be required to practice with teammates over the summer, but he knows that summer practice may enhance skills and team-building that, in turn, will enhance his opportunity to compete in the fall. While it may be difficult to redirect student-athletes' voluntary time away from sports-related activities, it should be possible to introduce limits in the overall time that studentathletes are required to devote to sports-related activities. One reform might be to prohibit student-athlete access to practice and training facilities during a period of time in the summer. ${ }^{360}$ A reform that clearly limits overall mandatory time devoted to a sport would be to limit the number of total competitions, ${ }^{361}$ particularly as conference realignment has led to more team travel to get to competitions.

\section{d. Assistance in Evaluating Professional Potential}

Some student-athletes have the potential or desire to play professionally. They may want to consider whether it is in their financial interest to leave college before graduating to pursue professional careers. They also may want help in wending their way through the intricacies of contract negotiations. Currently, however, they may not seek the assistance of lawyers or sports agents in considering whether to sign a professional contract because to do so renders them ineligible for college competition. ${ }^{362}$ The concerns

\footnotetext{
359 NCAA MANUAL, supra note $1, \S 17$.

360 As with any reform, there are potential negative consequences. This proposal, for example, might impel student-athletes to seek practice and training facilities elsewhere. Those alternatives may not be monitored for health and safety in the way that university weight rooms and practice facilities are monitored.

361 There are fifty-six regular-season baseball games; for teams in post-season, there are regionals, super regionals, and the College World Series. NCAA MANUAL, supra note $1, \S$ 17.2.5.2. Teams also compete in a conference tournament. Id. § 17.2.5. Basketball and track and field span two seasons. Many sports have a non-championship season with additional games played. E.g., id. $\S \S 17.2 .1 .1,17.20 .1$. The increase in games is notable. In 1969 , there were nine total football games plus a bowl game; today there are twelve regular season games plus a bowl game. In most FBS conferences, there is a conference championship game. The new FBS championship will add yet another game for two teams. See Potuto, They Take Classes, supra note 49, at 338 n.161. The NCAA Men's Basketball Tournament began with sixteen teams; there are now sixty-eight teams, regionals and superregionals. Id. at $339 \mathrm{n} .166$.

362 NCAA bylaws permit universities to create professional advising panels. NCAA MANUAL, supra note $1, \S 12.3 .4$. These may be insufficient to provide the advice needed and, in any event, are unavailable to prospective baseball student-athletes needing assistance to decide whether to enter the professional baseball draft or attend college.
} 
about agent influence are not negligible, particularly if a studentathlete thereafter elects to remain in school. ${ }^{363}$ Nonetheless, we believe the equities are in favor of permitting student-athletes to receive assistance.

Litigation involving Andrew Oliver, a baseball pitcher at Oklahoma State University, suggests that courts are inclined to agree, at least if the agent is also a lawyer. ${ }^{364}$ Oliver was rendered ineligible for intercollegiate competition because his lawyer was present during contract discussions between him and the Minnesota Twins baseball team-conduct that the NCAA deemed prohibited agent involvement. ${ }^{365}$ The trial judge held that preventing a student-athlete from having the assistance of counsel in contract negotiations violated Ohio public policy. ${ }^{366}$

\section{e. Independent Voice in Student-Athlete Reinstatement Processes}

Currently, student-athletes have no independent opportunity to plead their case when they are declared ineligible for competition and seek reinstatement of eligibility. ${ }^{367}$ We believe they should have independent access to reinstatement processes when they face the loss of half a season or more of competition opportunities and they contest factual conclusions adverse to them that were reached by their universities.

\section{f. Health and Well-Being}

As previously discussed, universities may cover the full cost of medical attention for their student-athletes. But medical aid is only one of many initiatives that would enhance student-athlete health and well-being. Two other initiatives may serve as examples. First, there should always be a trainer or physician on the sideline and at practice, at least in any contact sport or where the risk of concussions or

363 For a discussion of some of the problems, see supra note 128 and accompanying text.

364 Oliver v. NCAA, 920 N.E.2d 203 (Ohio Ct. Com.Pl. 2009), vacated pursuant to settlement. The judge also expressed concern with NCAA bylaws that permit studentathletes to hire lawyers but then "attempt to control what that lawyer does." Id. at 214.

365 Id. at 206-07. NCAA amateurism bylaws permit lawyers to represent studentathletes but not to act as agents for them. NCAA MANUAL, supra note $1, \S 12.3 .2$.

366 Oliver, 920 N.E.2d at 214-15.

367 A discussion of student-athlete reinstatement is well beyond the scope of this Article. For details on its operation, see Josephine (Jo) R. Potuto, The NCAA Rules Adoption, Interpretation, Enforcement, and Infractions Processes: The Laws that Regulate Them and the Nature of Court Review, 12 VAND. J. ENT. \& TECH. L. 257, 283-87 (2010). 
serious injury is high in comparison to other sports. Second, there should be no limits on the number of meals that may be provided to scholarship student-athletes in or out of season.

\section{B. Aligning with the Collegiate Model}

The collegiate model extends beyond imposing restraints on commercialization. It also extends beyond the equitable treatment of individual student-athletes and the particular benefits provided to them. Overall, there needs to be assurance that college sports are administered for all student-athletes consistent with the campus environment and the primacy of academic values.

One example of a failure to align conduct with the collegiate model relates to the so-called "one-and-dones"-men's basketball studentathletes who are in college only because the NBA collective bargaining agreement forecloses their entry into the NBA until one year after high school graduation. ${ }^{368}$ Entry rules for professional sports admittedly are outside the NCAA's control. Within its control, however, is revising the metric used by the Division I Committee on Academic Performance to calculate a team's academic progress rate (APR). ${ }^{369}$ Currently, a team suffers no APR consequence when a scholarship student-athlete fails to return to school the academic year after his season ends because he signed a professional contract. The metric should be revised to impose an APR consequence if a studentathlete goes pro after only one year on campus. At the margin, this will affect coach recruiting behaviors. Coaches who recruit several one-and-dones will need to change their behavior or risk penalties that may be imposed for a low APR team score.

\section{The Flip Side of Name and Likeness: Student-Athletes Marketing Themselves}

As previously discussed, NCAA bylaws limit the circumstances in which student-athletes may participate in promotions and commercial ventures. Student-athletes currently are not paid for those activities; at most, they can be reimbursed for actual and necessary expenses. ${ }^{370}$

\footnotetext{
368 Myron Medcalf, Roots of One-and-Done Rule Run Deep, ESPN.COM (June 26, 2012), http://espn.go.com/mens-college-basketball/story/_id/8097411/roots-nba-draft-one -done-rule-run-deep-men-college-basketball.

369 See supra notes 45-46 and accompanying text.

370 NCAA MANUAL, supra note $1, \S 12.5 .1 .1(\mathrm{f})$.
} 
There is another side to the coin: student-athletes also are prohibited from independently arranging and participating in promotions and other commercial ventures. ${ }^{371}$

\section{Emma Watson vs. Sam Keller}

College music majors can play in bands for money and still also play in a university marching band and receive a universityadministered scholarship. Emma Watson, the actress who played Hermione Grainger in the Harry Potter movies, attended Brown University. ${ }^{372}$ Acting in the Harry Potter movies did not disqualify her from appearing in amateur campus theatrical productions. No rule prevented her from getting a scholarship because she made movies on her summer break or might have done a commercial. No one regulated her spare time or limited the number of hours of acting lessons she might take or the hours she might spend rehearsing and appearing in a campus production. ${ }^{373}$ Nothing prevented her from hiring an agent to market her acting talent. Why, then, are studentathletes treated differently?

One answer, set forth above, is that the NCAA amateurism principle protects the brand of college athletics and helps demark college athletics and student-athletes from professional team sports and professional players. There also is something qualitatively different between Emma Watson's situation and that of college athletes, even those who compete in football or men's basketball. Brown theater productions are independent activities that do not compete with theatrical productions at other universities. Emma Watson does not depend on a team logo or her affiliation with Brown to get film roles or product endorsements. There is no specter of a Brown booster willing to pay her to endorse products just to get her to attend Brown and perform in Brown amateur theatrical productions. Her name and likeness value has nothing to do with Brown.

371 Related to the independent marketing of their names and likenesses, student-athletes have the opportunity to leverage their athletic skills or reputations in other ways. One such example is employment by a booster because the student-athlete is an athlete. Here, too, the strict amateurism principle should give way, even though illicit booster conduct may result.

372 Westerholm, Emma Watson's Brown University Professors Thought She Should Quit Acting, UNIV. HERALD (Aug. 6, 2013), http://www.universityherald.com/articles /4137/20130806/emma-watsons-brown-university-professors-thought-quit-acting.htm.

373 Student-athletes are subject to restrictions on mandatory play/practice time. See, e.g., NCAA MANUAL, $\S \S 17.02,17.1 .6,17.7 .6$. There also are restrictions on interactions with coaches. See, e.g., id. $\S 17.02 .1,17.02 .13$. 
There are significant enforcement issues inherent in permitting student-athletes to negotiate deals for the commercial use of their names and likenesses, and they should not be minimized. Certainly, there are donors willing to commit NCAA violations to get studentathletes to attend ${ }^{374}$ or remain ${ }^{375}$ at their schools. These same donors undoubtedly would be willing to enter into promotion, endorsement, or other commercial contracts with student-athletes for the same reason, and not as above-board, arms-length deals motivated by commercial interests.

A student-athlete also could make money off his name and likeness in ways much more quickly than through commercial contracts. Signing autographs for money is one such example. ${ }^{376}$ Booster payments here might substitute for the five-hundred-dollar handshake.

The NCAA enforcement staff likely will be unable to untangle the strings of these donor deals except in the most blatant and egregious situations. ${ }^{377}$ The result would be enforcement directed only at the most egregious cases, or perhaps NCAA bylaws that place no limits on how these deals are done. The concomitant result would be even more competitive imbalance among collegiate programs or a "wild

374 In one case, an Alabama booster gave an SUV and paid $\$ 160,000$ in cash to "deliver" a football prospect to the University of Alabama. UNIVERSITY OF ALABAMA PUBLIC INFRACTIONS REPORT NO. 193 (2002). In the same case, boosters gave \$20,000 to a prospective student-athlete and his family. Id. In a case involving the University of Michigan, a booster gave four student-athletes cash and benefits totaling more than $\$ 600,000$. UNIVERSITY OF MICHIGAN PUBLIC INFRACTIONS REPORT NO. 208 (2003).

375 In a case involving Southern Methodist University, the so-called "death penalty" was imposed - for the only time- by the Division I Committee on Infractions. See NCAA MANUAL, supra note $1, \S 19.5$.2.3.2. Boosters made weekly cash payments to members of the football team. NCAA DIV. I COMM. ON INFRACTIONS, INFRACTIONS REPORT (Feb. 25, 1987). See also DAVID Whitford, A PAYroll to MEet: A StORY of Greed, CORRUPTION, AND FOOTBALL AT SMU (1989).

376 Johnny Manziel was suspected of selling his autograph for cash. Jeremy Fowler, NCAA's Manziel Investigation Opens Player-Rights Discussion at Right Time, CBSSPORTS.COM (Aug. 4, 2013, 10:45 PM), http://www.cbssports.com/collegefootball /writer/jeremy-fowler/23017082/ncaas-manziel-investigation-opens-playerrights -discussion-at-right-time.

377 The fact that disentanglement may not be possible was judicially acknowledged in a related area in litigation involving Jeremy Bloom, a student-athlete on the University of Colorado football team who was also an Olympic skier. Bloom v. NCAA, 93 P.3d 621 (Colo. App. 2004). Bloom's situation also involved untangling the reason for the endorsement contract; Bloom claimed that he endorsed products as a skier and, therefore, should not lose his college eligibility to play football. The NCAA successfully defended amateurism bylaws that prohibited Bloom from endorsing products on the ground that it would be too difficult to discern the basis on which he was awarded the endorsement contract. 
west" permitting program donors to bid against each other for elite athletes under the guise of projected commercial contracts.

Yet another issue is whether a student-athlete should be permitted to engage an agent to negotiate commercial contracts for him because of the potential negative consequences that might ensue from the relationship between an agent and a student-athlete. Not all agents have their clients' best interests at heart. ${ }^{378}$ Some agents might define client interests only in terms of post-college professional contracts, not in terms of student-athletes' best interests in their college educations or in collegiate competition. An agent might tell a hitter to swing away, no matter what the coach says, because homeruns (even if combined with a higher strikeout rate) more readily will attract the attention of pro scouts. Similarly, an agent might tell a football player to sit out to avoid risk of injury. Finally, an agent might urge even a student-athlete with marginal talent to leave school rather than to stay and complete his education.

One possibility for avoiding significant enforcement issues might be for student-athlete name and likeness marketing deals to be achieved by group licensing and marketing arrangements. ${ }^{379}$ This possibility is not without problems. A couple of the issues that would arise are who would manage these arrangements and how revenues would be divided. ${ }^{380}$ Group licensing and marketing arrangements would also trigger some of the same issues discussed previously regarding when and how funds would be distributed to studentathletes.

Despite the potential for very significant enforcement issues, we believe that individual student-athletes should be permitted to market their own names and likenesses, particularly if group marketing and licensing arrangements pose too many problems to be feasible. Our reasons are several.

First, and foremost, the money swirling around college athletic programs and coaches makes it difficult credibly to foreclose studentathletes from negotiating their own deals. Permitting them to do so responds to the perception that everyone feeds at the trough except

\footnotetext{
378 See ZiMBALIST, supra note 8, at 25-26 (quoting sports agent Mike Trope's statement, "I would no sooner abide by the rules and regulations of the NCAA than I would the Ku Klux Klan").

379 This possibility was suggested by the Keller/O'Bannon plaintiffs as a way to handle student-athlete payments consistent with the collegiate model.

380 This latter issue was part of the reason the Keller/O'Bannon judge declined to certify a subclass for damages.
} 
student-athletes, and it does so without starting the slide down the slippery slope toward pay for play that might arise should the plaintiffs succeed in the Keller/O'Bannon litigation.

Second, and most important, permitting them to do so will not lead athletic departments to accelerate their search for funds, resulting in yet more commercialization, or leading to revenue redistribution that further drains campus funds or that has negative impact on nonrevenue sports.

Third, notwithstanding the specter of donors with illicit motives manipulating the process, we believe there will be few elite studentathletes who will find opportunities to market their names and likenesses for any significant amount of money. In any event, the major FBS programs with donors willing to spend big money-licitly or illicitly - to assure that elite athletes enroll at their universities already have significant advantages that provide them a significant competitive edge. We doubt that student-athlete independent deals will affect that much, if at all.

Finally, the mechanisms discussed above regarding the establishment of a trust to handle the bulk of the funds also could be employed in the context of individual contracts.

\section{What's Good for the Goose}

The questions addressed so far focus on the name and likeness value of football or men's basketball student-athletes independent of their universities ${ }^{381}$ and on the value they contribute to overall team revenues. $^{382}$ There are two partners in the valuation dance, however. If student-athletes contribute to the overall value of an athletic program, then it also seems true that some of the marketing and endorsement value of a student-athlete, while enrolled and even after he turns professional, is because his college uniform said, for example, "Notre Dame" on the back. ${ }^{383}$

\footnotetext{
381 As previously noted, this question does not lend itself to econometric modeling.

382 This is the particular focus of the econometric model of student-athlete valuation provided supra Part VI.

383 An analogous situation is a professor's assignment of patent and other intellectual property rights for which she did research while employed at a university. A professor at a research university agrees that the university holds the patent should she invent something while on staff. It is her effort and creativity and her energy and sweat. But she uses the university's resources and facilities. She attends conferences and gets ideas because she is at the university. She publishes because she is a university professor.
} 
Consider Tim Tebow, the 2007 Heisman-Award-winning quarterback at the University of Florida. $^{384} \mathrm{He}$ was widely acknowledged by football gurus as lacking the talent to play quarterback in the NFL, ${ }^{385}$ and he currently works as a college football analyst. ${ }^{386}$ If he played in an NFL-equivalent to baseball's minor leagues and not for Head Coach Urban Meyer at Florida, would he have achieved the fame that got him a multi-million dollar contract, a first round NFL draft pick, ${ }^{387}$ and the opportunity for major endorsement and promotion contracts?

Were student-athletes able to independently market their names and likenesses while still eligible to compete, universities might be entitled to their share of the royalties derived while student-athletes are enrolled, and perhaps for some time thereafter. ${ }^{388}$ Similarly, if the Keller/O'Bannon case results in student-athlete legal entitlement to a share of revenues from university-licensed activities in which their names or likenesses are used or from games in which they appear, then perhaps universities should share in revenues from professional team and marketing contracts that are signed after a student-athlete turns professional.

\section{$\mathrm{X}$ \\ ALL THINGS CONSIDERED}

Providing benefits and services to student-athletes along the lines we propose may carry a hefty price tag. ${ }^{389}$ The question is how universities might adjust their operations to account for more spending directed at student-athletes.

\section{A. Negative Consequences}

One response, alluded to by Judge Wilken in the Keller/O'Bannon litigation, is that universities might move from Division I to Division

\footnotetext{
384 See HEISMAN TROPHY, http://www.heisman.com/winners/t-tebow07.php (last visited Mar. 8, 2014).

385 Broncos Pick Tim Tebow in First Round, HufFINGTON POST (June 22, 2010, 6:12 AM), http://www.huffingtonpost.com/2010/04/22/broncos-pick-tim-tebow-in_n_548874 .html.

386 Tebow Lands Broadcasting Job, N.Y. TIMES (Dec. 31, 2013), http://www.nytimes .com/2013/12/31/sports/football/tebow-lands-broadcasting-job.html?_r=0.

387 Broncos Pick Tim Tebow in First Round, supra note 386.

388 Valuation will not be easy. See, e.g., Morris, supra note 197.

389 The revenue consequence to universities might also be high should the plaintiffs prevail in the Keller/O'Bannon litigation regarding television revenues.
} 
III because they could not afford to pay royalties or compete for prospective student-athletes. ${ }^{390}$ While it is debatable whether reconfiguring a program as Division III should be classified as a negative consequence, other responses fall more clearly on the negative side.

If a university is to pay more money to and for student-athletes, it has two ways to respond. One is to cut spending. The other is to seek additional revenues.

On the cost-cutting side, one response with negative consequences would be to free up funds by eliminating some of the sports currently sponsored by universities. Given the large team size in football, were this to happen, Title IX gender equity requirements would mean that the impact of cuts would fall exclusively, or at least primarily, on men's non-revenue sports. ${ }^{391}$ Another response with negative consequences relates to scholarships. NCAA authority to provide scholarships - whether equivalencies, full rides, or, as proposed here, full cost of attendance-is not a mandate either to provide scholarships or to fully fund them. Should the Keller/O'Bannon plaintiffs prevail, some universities might cover lost revenues by decreasing the number of athletic scholarships offered. Perhaps the most clearly negative response related to increasing the available revenues to athletic departments would be for universities to redirect even more money from the greater campus to the athletic program without concomitant constraints imposed on athletic department spending.

The alternative to cutting costs is for athletic departments to undertake an even more accelerated search for revenue, producing even more commercialization and increasing the dependence on corporate sponsors. ${ }^{392}$ The arms race would not slow to a trot but, rather, would accelerate to a frenzied gallop.

\footnotetext{
390 This was one reason she gave for deciding that damages were too uncertain to permit class action certification to the damages subgroup in the Keller/O'Bannon litigation. Class Certification Order, supra note 151, at 18-22. Big Ten Commissioner Jim Delany suggested that Big Ten universities might make the same choice. See supra note 174. Should Big Ten universities make this choice, it would be for reasons other than financial. The "substitution effect" was an additional reason for denial of class action certification for the damages subgroup. See supra note 182 and accompanying text.

391 For a discussion of the implications for Title IX, see supra notes 212-16.

392 The search for revenues also could result in increased athletic department dependence on donors, with an accompanying increased risk of outside influence on athletic department decisions.
} 


\section{B. What Might Be Done}

There is broad consensus that athletic spending is unreasonably unrestrained. ${ }^{393}$ There are growing calls to realign college athletic programs with campus educational values and priorities. Realignment could occur if FBS universities held athletic department revenues, and the search for revenues, at stasis, and covered student-athlete compensation by paring down the arms race in facilities, coach salaries, and the ever-growing support staffs, particularly in football. Nonetheless, no university can act unilaterally. So, then, what is to be done?

One way to better align athletic spending with the collegiate model would be for the NCAA or conferences to require that every dollar generated in revenues by athletic departments must be matched by a dollar provided to the greater campus. ${ }^{394}$ And every dollar means every dollar, whether generated by donor contributions, payment in kind, marketing and promotion deals, or concession saleseverything, in fact, except stadium and arena ticket sales and existing skybox leases. Another way to rein in spending, recommended by the Rawlings Panel at the University of North Carolina-Chapel Hill, ${ }^{395}$ would be for the NCAA or conferences to impose caps on total team spending independent of salaries. ${ }^{396}$

The antitrust laws prohibit collective action that has an anticompetitive effect on competition. That does not mean, however, that all concerted action constitutes an antitrust violation. ${ }^{397}$ Because of the nature of organized athletic competition and the need for some

393 This includes university presidents and chancellors. KNIGHT COMM'N ON InTERCOllegiate ATHLETICS, ART AND SCIENCE GRoup LLC (Oct. 2009). It also includes athletic directors. See, e.g., Lewis Kamb, Big-Time Coaches Score Big-Time Perks, SeAtTle Times (Nov. 23, 2013, 7:31 PM), http://seattletimes.com/html/localnews /2022321329_coachespayxml.html.

394 We owe thanks to Harvey Perlman, Chancellor at the University of NebraskaLincoln, for first advancing this idea. See also REPORT OF THE RAWLINGS PANEL ON INTERCOLLEGIATE ATHLETICS AT THE UNIVERSITY OF NORTH CAROLINA AT CHAPEL HILl 20 (Aug. 29, 2013) [hereinafter Rawlings Report] (describing financial incentives based on athletic-to-academic spending ratios to discourage excessive spending on athletics and/or spending growth rates for athletics that are disproportionate with rates of change for academics).

395 The Rawlings Panel was appointed by the chancellor of the University of North Carolina-Chapel Hill to make recommendations regarding the role of athletics at the University. Rawlings Report, supra note 395, at 1.

396 This alternative was proposed by the Rawlings Panel. Id. at 20.

397 See supra note 147; NCAA v. Bd. of Regents, 468 U.S. 85 (1984); Standard Oil Co. v. United States, 221 U.S. 1 (1911). 
level of cooperation among competitors, the courts have allowed the NCAA a degree of freedom from regular antitrust analysis. ${ }^{398}$ For example, although in all other contexts salary caps are per se anticompetitive, NCAA employment of salary caps was evaluated under a rule of reason approach. ${ }^{399}$ Of particular importance when considering reforms, NCAA bylaws governing academic and amateurism policies to date have been treated as virtually per se legal under the antitrust laws. ${ }^{400}$ Requiring that dollars be returned to the campus to advance the academic mission seems on the right side of the line separating NCAA regulation that violates antitrust laws from that which does not.

\section{Final Thoughts}

There are, and need to be, differences among the various levels of amateur competition, and there are, and need to be, differences between collegiate competition and professional sports. So, call it the dichotomy between amateurism and professionalism. Call it an accommodation of different levels of talent. Call it the responsibility to protect young people from practice and competition to the detriment of their health or education. Call it what you will. There are, and need to be, differences among the various levels of amateur competition, competition associated with educational institutions, and professional sports.

An amateurism model based on a 1906 campus and college athletics world is ill suited to the modern realities of universities and athletic competition. The amateurism model must be recalibrated, but not at the expense of the central principles that student-athletes have to be "real" students and that athletic departments must be part of the campus environment and advance the academic mission. It is well

\footnotetext{
398 Bd. of Regents, 468 U.S. 85.

399 Law v. NCAA, 134 F.3d 1010 (10th Cir. 1998). The NCAA still lost: a degree of freedom is not insulation from clearly anticompetitive conduct. See also Bd. of Regents, 468 U.S. 85.

400 E.g., Smith v. NCAA, 139 F.3d 180 (3d Cir. 1998); Banks v. NCAA, 977 F.2d 1081, 1087-94 (7th Cir. 1992); see also Agnew v. NCAA, 683 F.3d 328, 340-46 (7th Cir. 2012) (NCAA bylaws are "presumptively procompetitive" when they promote "the revered tradition of amateurism in college sports" or the "preservation of the studentathlete in higher education," including most, if not all, eligibility bylaws, as well as NCAA bylaws that limit scholarship amounts to educational costs); McCormack v. NCAA, 845 F.2d 1338, 1343-45 (5th Cir. 1988); Justice v. NCAA, 775 F. Supp. 356, 379 (D. Ariz. 1983) (sanctions reasonably related to NCAA's goals of preserving amateurism and promoting fair competition).
} 
past time to realign aspiration with implementation. It is the right thing to do, and it should be done simply because it is right. It is also the eminently prudent thing to do.

If those within the world of intercollegiate athletics fail to be proactive with reforms, then those outside will step in to fill the void. $^{401}$ They may be right-hearted and right-headed, but they likely will have less understanding and experience with the intricacies and requisites of collegiate competition. They may adopt solutions that produce the right outcomes inefficiently or ineffectively or with serious negative ancillary consequences. To take charge of the future, universities, conferences, and the NCAA all need to act now. ${ }^{402}$

401 Congress periodically takes a look at what is happening in college athletics. See Josephine (Jo) R. Potuto, NCAA as State Actor Controversy: Much Ado About Nothing, 23 MARQ. SPORTS L. REV. 1, 37-38 (2012). It is doing so again. Steve Berkowitz, Proposal Aims to Protect Athletes at Wealthiest Schools, USA TODAY (Nov. 20, 2013, 6:10 PM), http://www.usatoday.com/story/sports/college/2013/11/20/ncaa-collegiate-student-athlete -protection-act-tony-cardenas/3649699/.

402 Indeed, reforms in the treatment of student-athletes that would enhance the collegiate model are also reforms that would undercut an argument that student-athletes are employees under federal and state labor laws. Consider, for example, Kain Colter's testimony before the NLRB of the number of hours he said he spends on football. See, e.g., Chris Johnson, Northwestern's Kain Colter States His Case College Football Union, SI.COM (Feb. 18, 2014), http://m.si.com/3969762/northwesterns-kain-colter-states-his-case -college-football-union/ (describing Colter's estimation of fifty hours devoted to the sport during the season). Consider the argument that might be made about the one-and-dones and the fact that they (or most of them) have no intention to be students or to graduate. Full exploration of that subject is beyond the scope of this Article. 

the Treatment of Student-Athletes

\section{APPENDIX TABLE 1: ECONOMETRIC ESTIMATES FROM THE COLLEGE FOOTBALL MODELS}

\begin{tabular}{|c|c|c|c|c|c|c|}
\hline \multirow[b]{2}{*}{ FB-Revenue } & \multicolumn{2}{|c|}{ Random-Effects } & \multicolumn{2}{|c|}{ Fixed-Effects } & \multicolumn{2}{|c|}{ IV Panel Model } \\
\hline & Estimate & p-value & Estimate & p-value & Estimate & p-value \\
\hline FB Win \% & 43,206 & 0.00 & 57,563 & 0.00 & 141,793 & 0.00 \\
\hline MedianAge100 & $-69,826$ & 0.73 & $-296,603$ & 0.14 & $-344,132$ & 0.13 \\
\hline Pop ‘000 & $-49,930$ & 0.01 & $-141,647$ & 0.00 & $-167,338$ & 0.00 \\
\hline InIncome100 & $-4,947,294$ & 0.54 & $-3,892,370$ & 0.61 & $-1,526,656$ & 0.86 \\
\hline InEntertain 100 & $4,124,643$ & 0.74 & $4,584,154$ & 0.70 & $1,742,340$ & 0.89 \\
\hline Students '000 & 409,027 & 0.00 & 272,465 & 0.10 & 253,864 & 0.15 \\
\hline$\%$ Out of State & 83,450 & 0.12 & 318,910 & 0.00 & 406,845 & 0.00 \\
\hline Attend '000 & 52,982 & 0.00 & 29,404 & 0.00 & 21,117 & 0.00 \\
\hline PctMenBA100 & $-285,443$ & 0.44 & $-431,737$ & 0.21 & $-623,290$ & 0.09 \\
\hline Year06 & 88,653 & 0.92 & $1,103,416$ & 0.19 & $1,269,777$ & 0.17 \\
\hline Year07 & $2,003,026$ & 0.03 & $3,073,947$ & 0.00 & $2,954,392$ & 0.00 \\
\hline Year08 & $1,971,393$ & 0.04 & $3,231,738$ & 0.00 & $3,254,772$ & 0.00 \\
\hline Year09 & $3,882,417$ & 0.00 & $4,660,036$ & 0.00 & $4,367,268$ & 0.00 \\
\hline Year10 & $5,258,123$ & 0.00 & $6,078,615$ & 0.00 & $6,276,710$ & 0.00 \\
\hline Year11 & $7,781,376$ & 0.00 & $8,992,557$ & 0.00 & $8,810,459$ & 0.00 \\
\hline Year12 & $7,949,267$ & 0.00 & $8,461,963$ & 0.00 & $8,523,518$ & 0.00 \\
\hline Constant & $24,000,000$ & 0.49 & $29,000,000$ & 0.38 & $27,100,000$ & 0.44 \\
\hline FB-Win\% ${ }^{*}$ & & & & & & \\
\hline Number 5-Star & 1.302 & 0.05 & 1.767 & 0.03 & 1.751 & 0.03 \\
\hline Number 4-Star & 0.242 & 0.10 & 0.029 & 0.90 & -0.023 & 0.92 \\
\hline Number 3-Star & 0.161 & 0.08 & 0.077 & 0.57 & -0.050 & 0.72 \\
\hline Head Win\% & 0.188 & 0.09 & -0.031 & 0.78 & -0.083 & 0.44 \\
\hline Head Bowls & -2.098 & 0.05 & -0.743 & 0.51 & -0.037 & 0.97 \\
\hline Staff Win\% & 0.236 & 0.09 & -0.021 & 0.88 & -0.029 & 0.83 \\
\hline Staff Bowls & 0.079 & 0.43 & -0.013 & 0.91 & -0.061 & 0.60 \\
\hline Staff Size & -0.333 & 0.27 & 0.121 & 0.71 & 0.951 & 0.03 \\
\hline APR & 0.000 & 0.95 & 0.000 & 0.92 & 0.001 & 0.56 \\
\hline $\operatorname{lnFBOp}$ & 3.768 & 0.01 & 2.478 & 0.10 & 14.431 & 0.00 \\
\hline Sched.Strength & -1.715 & 0.00 & -1.506 & 0.00 & -1.236 & 0.00 \\
\hline Constant & 0.430 & 0.98 & 42.119 & 0.05 & -182.332 & 0.13 \\
\hline
\end{tabular}

* The first-stage IV equation (reduced form) also includes all the exogenous variables from the revenue equation. 


\section{APPENDIX TABLE 2: ECONOMETRIC ESTIMATES FROM THE MEN'S COLLEGE BASKETBALl MODELS}

\begin{tabular}{|c|c|c|c|c|c|c|}
\hline \multirow[b]{2}{*}{ BB-Revenue } & \multicolumn{2}{|c|}{ Random-Effects- } & \multicolumn{2}{|c|}{ Fixed-Effect- } & \multicolumn{2}{|c|}{ IV Panel Model } \\
\hline & Estimate & p-value & Estimate & p-value & Estimate & p-value \\
\hline BB Win \% & 3,236 & 0.69 & 10,352 & 0.20 & 34,562 & 0.38 \\
\hline MedianAge100 & 59,276 & 0.36 & 12,207 & 0.86 & $-12,176$ & 0.88 \\
\hline Pop ‘000 & 3,767 & 0.52 & 939 & 0.92 & -669 & 0.95 \\
\hline InIncome 100 & $-1,911,758$ & 0.48 & $-1,236,595$ & 0.65 & $-1,302,091$ & 0.63 \\
\hline $\operatorname{lnEntertain} 100$ & $-1,165,405$ & 0.78 & $-2,042,883$ & 0.62 & $-2,032,784$ & 0.63 \\
\hline Students ' 000 & 60,591 & 0.13 & 27,844 & 0.67 & 16,026 & 0.82 \\
\hline$\%$ Out of State & 17,905 & 0.32 & 21,860 & 0.51 & 27,152 & 0.43 \\
\hline Attend ' 000 & 23,135 & 0.00 & 10,643 & 0.01 & 5,709 & 0.52 \\
\hline$\%$ MenBA 100 & 177,984 & 0.20 & 197,569 & 0.16 & 165,787 & 0.27 \\
\hline Year06 & $-192,286$ & 0.55 & 61,860 & 0.85 & 155,920 & 0.66 \\
\hline Year07 & 431,597 & 0.19 & 688,930 & 0.03 & 796,425 & 0.03 \\
\hline Year08 & 181,999 & 0.59 & 447,449 & 0.18 & 495,256 & 0.15 \\
\hline Year09 & $1,174,726$ & 0.00 & $1,416,382$ & 0.00 & $1,490,130$ & 0.00 \\
\hline Year10 & $1,310,685$ & 0.00 & $1,589,871$ & 0.00 & $1,684,699$ & 0.00 \\
\hline Year11 & $1,803,793$ & 0.00 & $2,140,820$ & 0.00 & $2,271,020$ & 0.00 \\
\hline Year12 & $1,812,556$ & 0.00 & $2,085,088$ & 0.00 & $2,164,204$ & 0.00 \\
\hline Constant & $29,100,000$ & 0.02 & $32,900,000$ & 0.01 & $34,300,000$ & 0.01 \\
\hline BB-Win\%* & & & & & & \\
\hline Number 5-Star & 1.962 & 0.00 & 1.197 & 0.04 & 0.613 & 0.25 \\
\hline Number 4-Star & 0.414 & 0.23 & -0.145 & 0.73 & -0.166 & 0.67 \\
\hline Number 3-Star & 0.380 & 0.42 & 0.136 & 0.79 & 0.261 & 0.58 \\
\hline lnOpExpense & 2.847 & 0.00 & 2.474 & 0.01 & 9.454 & 0.00 \\
\hline Sched.Strength & -0.081 & 0.81 & 0.086 & 0.82 & 0.236 & 0.50 \\
\hline onstant & 19.539 & 0.16 & 23.535 & 0.14 & 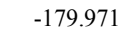 & 0.02 \\
\hline
\end{tabular}

* The first-stage IV equation (reduced form) also includes all the exogenous variables from the revenue equation. 